Aus der Abteilung Medizinische Mikrobiologie

(Prof. Dr. med. U. Groß)

im Zentrum Hygiene und Humangenetik

der Medizinischen Fakultät der Universität Göttingen

\title{
Nachweis von Toxoplasma gondii in Muskelgewebe von experimentell infizierten Hühnern und Schweinen
}

\author{
INAUGURAL - DISSERTATION \\ Zur Erlangung des Doktorgrades \\ der Medizinischen Fakultät der \\ Georg-August-Universität zu Göttingen
}

vorgelegt von

Maisalreem Muhammad

aus

Tartous - Syrien

Göttingen 2014 
Dekan:

Prof. Dr. rer. nat. H. K. Kroemer

1. Berichterstatter: Prof. Dr. rer. nat. C. Lüder

2. Berichterstatter: Prof. Dr. St. Pöhlmann

3. Berichterstatter: Prof. Dr. Margarete Schön

Tag der mündlichen Prüfung: 24.09.2014 


\section{Inhaltsverzeichnis}

1. EINLEITUNG

1.1 Toxoplasma gondii

1.2 Lebenszyklus von T. gondii.

1.3 Übertragung von T. gondii auf Mensch und Tier

1.3.1 Oozysten als Infektionsquelle.

1.3.2 Gewebezysten als Infektionsquelle

1.3.3 Tachyzoiten als Infektionsquelle

1.4 Die medizinische Bedeutung von T. gondii.....

1.5 Diagnostik

1.6 Therapie und Prävention 10

1.7 Die Prävalenz von T. gondii im Schwein

1.8 Die Prävalenz von T. gondii im Huhn 13

1.9 Ziel der Arbeit. 14

2. MATERIAL UND METHODEN 15

2.1 Material 15

2.1.1 Geräte. .15

2.1.2 T. gondii. .15

2.1.3 Tiergewebe .16

2.1.4 Genomische DNA-Präparationen von Coccidia-Parasiten. .16

2.1.5 Kits .16

2.1.6 Primer 17

2.1.7 Chemikalien und Reagenzien .18

2.2 Methoden 19

2.2.1 Experimentelle Infektion von Schweinen und Hühnern mit $T$. gondii und Gewinnung von Gewebeproben

2.2.2 Zellkultur von T. gondii und Parasitenisolierung .20

2.2.3 Gewinnung von Mausgewebe 20 
2.2.4 Etablierung einer Standardkurve für quantitative PCR …................................21

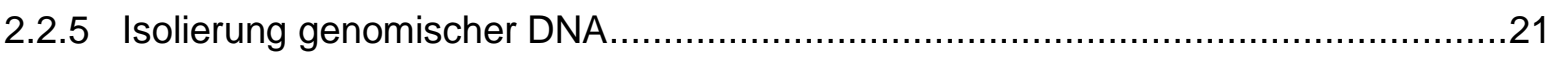

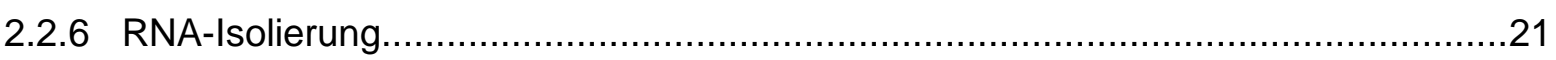

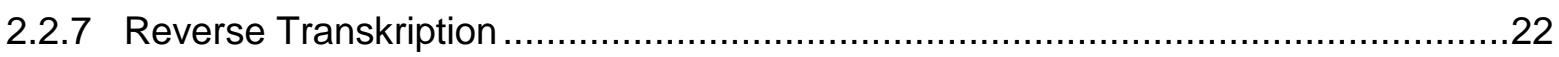

2.2.8 Quantitative real-tim Polymerasekettenreaktion ...............................................23

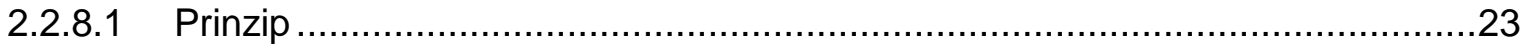

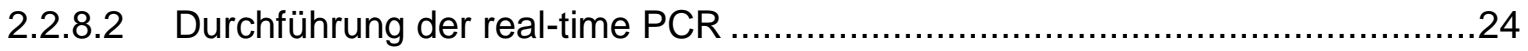

2.2.9 Nested PCR zum Nachweis von T. gondii genomischer DNA .............................25

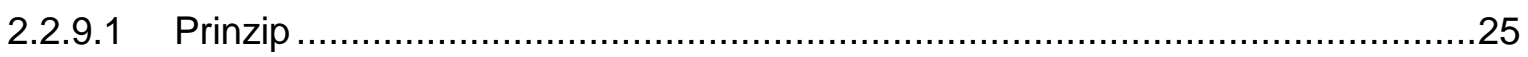

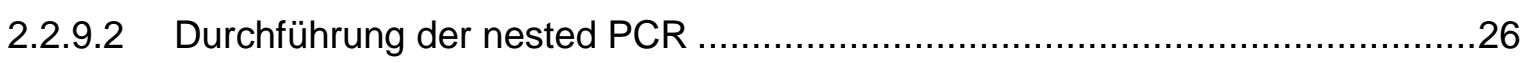

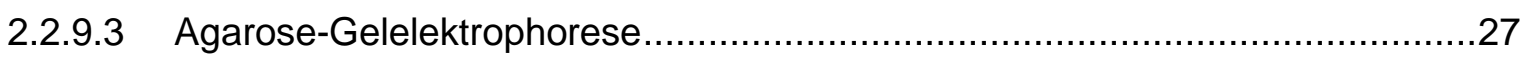

2.2.10 Überprüfen der Spezifität der Toxoplasma-real-time PCR mit DNA anderer CoccidiaParasiten .....

2.2.11 Nachweis von Toxoplasma-mRNA mittels reverser Transkriptase-real-time PCR

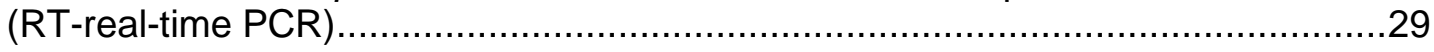

3.1 Nachweis von Toxoplasma-DNA in Mausgewebe und Bestimmung von

Parasitenmengen mittels real-time PCR

3.1.1 Nachweis von T. gondii-DNA mittels real-time PCR mit Primern Toxo9/Toxo11 ......31

3.1.2 Nachweis von T. gondii-DNA mittels real-time PCR mit Primern Toxo4 und Toxo5.35

3.2 Weitere Untersuchungen zur Sensitivität des Toxoplasma-Nachweises in

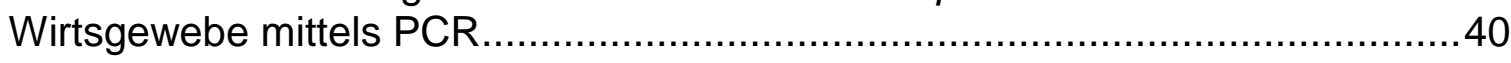

3.2.1 Nachweis von T. gondii-DNA im Mausgewebe mittels nested PCR ......................40

3.2.2 Einfluss von Wirtsgewebe auf die T. gondii-529-bp-real-time PCR.......................42

3.3 Spezifität der 529-bp-real-time PCR ………...........................................46

3.4 Nachweis von Toxoplasma gondii in Gewebeproben experimentell infizierter Schweine

3.4.1 Serologischer Nachweis der Toxoplasma-Infektion mittels Enzyme Linked Immunosorbent Assay (ELISA) ............................................................... 48

3.4.2 Nachweis von T. gondii-DNA in Schweinegewebe mittels real-time PCR ...............50

3.5 Nachweis von Toxoplasma gondii in Hühnern .......................................53

3.5.1 Serologischer Nachweis der Toxoplasma-Infektion mittels des Direktagglutinationstests (Toxoscreen DA). .54

3.5.2 Nachweis von T. gondii-DNA in Hühnergeweben mittels real-time PCR. 
3.6 Nukleinsäure-basierte Untersuchung der Viabilität von T. gondii im Gewebe experimentell infizierter Hühner und Schweine ......................................... 58

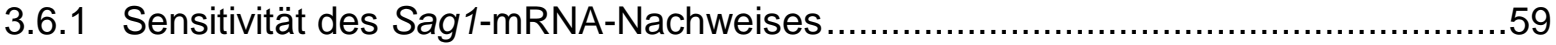

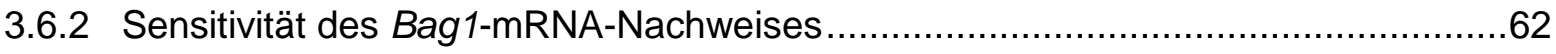

3.6.3 Nachweis von Toxoplasma-mRNA im Gewebe experimentell infizierter Hühner und Schweine.

4. DISKUSSION .68

4.1 Nachweis von Toxoplasma-DNA in Mausgewebe und Bestimmung von Parasitenmengen mittels real-time PCR .68

4.2 Weitere Untersuchungen zur Sensitivität und Spezifität des ToxoplasmaNachweises in Wirtsgewebe mittels PCR

4.3 Nachweis von Toxoplasma gondii in Gewebeproben experimentell infizierter Schweine

4.4 Nachweis von Toxoplasma gondii in Gewebeproben experimentell infizierter Hühner

4.5 Nukleinsäure-basierte Untersuchung der Viabilität von T. gondii im Gewebe experimentell infizierter Hühner und Schweine

5. ZUSAMMENFASSUNG 


\section{Abkürzungsverzeichnis}

$\begin{array}{ll}\text { AIDS } & \text { acquired immune deficiency syndrom } \\ \text { bp } & \text { Basenpaar } \\ \text { cDNA } & \text { komplementäre DNA (complementary DNA) } \\ \text { CP } & \text { Crossing point } \\ \text { DAT } & \text { Direktagglutinationstest } \\ \text { DNA } & \text { Desoxyribonukleinsäure } \\ \text { ELISA } & \text { Enzym-linked-Immunosorbent-Assay } \\ \text { FCS } & \text { foetales Kälberserum } \\ \text { fg } & \text { femtogramm } \\ \text { HAART } & \text { hochaktive antiretrovirale Therapie } \\ \text { HAT } & \text { Hämagglutinationstest } \\ \text { HIV } & \text { human immunodeficiency virus } \\ \text { IFAT } & \text { Immunofluoreszenz-Antikörper-Test } \\ \text { IgG } & \text { Immunglobulin G } \\ \text { kg } & \text { Kilogramm } \\ \text { LAT } & \text { Latexagglutinationstest } \\ \text { MAT } & \text { modifizierter Agglutinationstest } \\ \text { mRNA } & \text { Boten-RNA (messenger RNA) } \\ \text { PBS } & \text { Phosphat-gepufferte Kochsalzlösung (phosphate buffered saline) } \\ \text { PCR } & \text { Polymerasekettenreaktion } \\ \text { RNA } & \text { Ribonukleinsäure } \\ \text { RPMI } & \text { Roswell Park Memorial Institute Medium } \\ \text { RT } & \text { reverse Transkriptase } \\ \text { SD } & \text { Standardabweichung (standard deviation) } \\ \text { S.E.M } & \text { Standardfehler (standard error of the mean) } \\ T . g o n d i i & \text { Toxoplasma gondii } \\ \text { Tris } & \text { Tris(hydroxymethyl)-Aminomethan } \\ \text { UV } & \text { ultraviolett } \\ & \end{array}$




\section{Einleitung}

\subsection{Toxoplasma gondii}

Die Toxoplasmose ist eine der häufigsten ubiquitär vorkommenden Infektionskrankheiten, die durch den Einzeller Toxoplasma gondii ausgelöst wird. Der obligat intrazelluläre Gewebeparasit kommt in allen Regionen der Welt vor, hat ein ungewöhnlich breites Wirtsspektrum und kann verschiedene Wirtszellen infizieren (Dubey und Beatti 1988; Dubey et al. 1998).

Toxoplasma gondii wurde 1908 erstmalig von Nicolle und Manceaux entdeckt. Der Name Toxoplasma wurde nach der Morphologie des Parasiten (griechisch: toxon Bogen, plasma Form) gewählt. In den 1920er und 1930er Jahren erfolgte die erste Beschreibung der konnatalen Toxoplasmose (Wolf et al. 1939). Der vollständige Lebenszyklus wurde mit der Entdeckung der sexuellen Entwicklung innerhalb des Dünndarms des Endwirtes aufgeklärt (Frenkel et al. 1970; Hutchison et al. 1970; Ferguson et al. 1974).

T. gondii ist ein eukaryotischer Einzeller, der innerhalb des Stammes Apikomplexa zur Unterklasse Coccidia gehört. Die Mitglieder des Stammes Apikomplexa sind durch den am Vorderende des Parasiten vorhandenen Apikalkomplex gekennzeichnet. Der Apikalkomplex besteht aus dem Konoid und den Rhoptrien, die dem Parasiten die Adhärenz und die Invasion in die Wirtzelle ermöglichen. Der Stamm Apikomplexa umfasst weitere wichtige Humanpathogene (Plasmodium spp: Erreger der Malaria, Cryptosporidium spp: opportunistisches Humanpathogen und Tierpathogen) und Tierpathogene (Eimeria: Erreger der Kokzidiose der Hühner, Theileria: durch Zeckenbisse auf das Rind übertragener Parasit, Babesia, Neospora und Sarcocystis spp).

\subsection{Lebenszyklus von T. gondii}

T. gondii hat einen komplexen Lebenszyklus, in dem drei verschiedene infektiöse Entwicklungsstadien unterschieden werden: Sporozoiten (innerhalb von sporulierten Oozysten), Tachyzoiten (Endozoiten) und Bradyzoiten (Zystozoiten, innerhalb von Zysten). Der Lebenszyklus von T. gondii erfolgt in zwei Wirtsgruppen. Als Endwirte 
dienen die Feliden (Katzenartige) mit einer geschlechtlichen und ungeschlechtlichen Vermehrung des Parasiten. Als Zwischenwirte können des Weiteren alle warmblütigen Tiere, einschließlich der Nutztiere und des Menschen fungieren. In ihnen erfolgt die Entwicklung ausschließlich ungeschlechtlich (Frenkel et al. 1970; Dubey und Beatti 1988; Tenter et al. 2000).

Nach der Infektion eines Zwischenwirtes mit Oozysten oder Bradyzoiten wandeln sich die Parasiten in Tachyzoiten um, die alle kernhaltigen Zellen infizieren können (Dubey et al. 1998). Die Tachyzoiten (griechisch: tachys schnell) sind halbmondförmig, mit einer Länge von 4-8 $\mu \mathrm{m}$ und einer Breite von 2-4 $\mu \mathrm{m}$ (Montoya und Liesenfeld 2004).

Durch ungeschlechtliche Endodyogenie vermehren sich die Tachyzoiten sehr schnell bis letztendlich die Wirtszelle vollständig gefüllt ist und rupturiert. Die freigewordenen Parasiten können benachbarte Wirtszellen infizieren oder sich über die Blut- bzw. Lymphbahnen verbreiten und verschiedene Organe, wie z.B. das Zentralnervensystem, das Auge, die Skelett- und Herzmuskulatur oder die Plazenta befallen (Montoya und Liesenfeld 2004). Nachdem eine adäquate Immunabwehr eingesetzt hat, findet eine Stadienkonversion von den Tachyzoiten zu Bradyzoiten statt, die sich innerhalb von Gewebezysten entwickeln, in denen sie sich langsam ebenfalls durch Endodyogenie vermehren. Die Bradyzoiten (griechisch: bradys langsam) haben eine Länge von $7 \mu \mathrm{m}$ und eine Breite von 1,5 $\mathrm{m}$. Der Zellkern liegt näher am hinteren Pol, während dieser bei Tachyzoiten mehr zentral gelagert ist (Hill et al. 2005). Die Zysten können einen variablen Durchmesser von 0,5 - $70 \mu \mathrm{m}$ haben und hunderte von Bradyzoiten enthalten.

Obwohl Gewebezysten sich auch in viszeralen Organen (z. B. Lunge, Niere und Leber) entwickeln können, werden sie bevorzugt im Zentralnervensystem, im Auge und in der Skelett- und Herzmuskulatur gefunden. Des Weiteren persistieren die Gewebezysten im Zwischenwirt ein Leben lang ohne jedoch in den meisten Wirten offensichtliche klinische Symptome zu verursachen (Dubey et al. 1998; Tenter et al. 2000; Hill et al. 2005).

Nimmt eine Katze diese Zysten mit der Nahrung auf, werden die Bradyzoiten freigesetzt und durchlaufen eine asexuelle Endodyogenie. Nach mehreren Endodyogenien fängt in den Epithelzellen des Dünndarms der Katze die sexuelle Entwicklungsphase (Gamogonie) an, die letztendlich zur Bildung der Oozysten führt. Diese werden mit dem Kot der Katze ausgeschieden und sind zunächst unsporuliert und nicht infektiös. 
Die Sporogonie läuft außerhalb der Katze abhängig von der Temperatur und Luftfeuchtigkeit innerhalb von 1-5 Tagen ab. Die sporulierten Oozysten enthalten zwei Sporozysten mit je vier Sporozoiten (Dubey und Beattie 1988; Tenter et al. 2000). Diese infektiösen Oozysten sind sehr resistent gegen ungünstige Umweltbedingungen und können 18 Monate im Freien überleben (Frenkel 2000).

Die Katze ist jedoch auch in der Lage, nach Aufnahme von Tachyzoiten oder Oozysten Oozysten auszuscheiden (Dubey und Frenkel 1972). Anhand der Präpatenzperiode und der Häufigkeit der Oozystenausscheidung kann auf das Stadium geschlossen werden, welches von der Katze aufgenommen wurde. Laut Dubey und Frenkel (1976) scheiden ungefähr 50\% der Katzen Oozysten nach der Aufnahme von Tachyzoiten bzw. Oozysten aus und fast alle Katzen nach der Aufnahme von Gewebezysten.

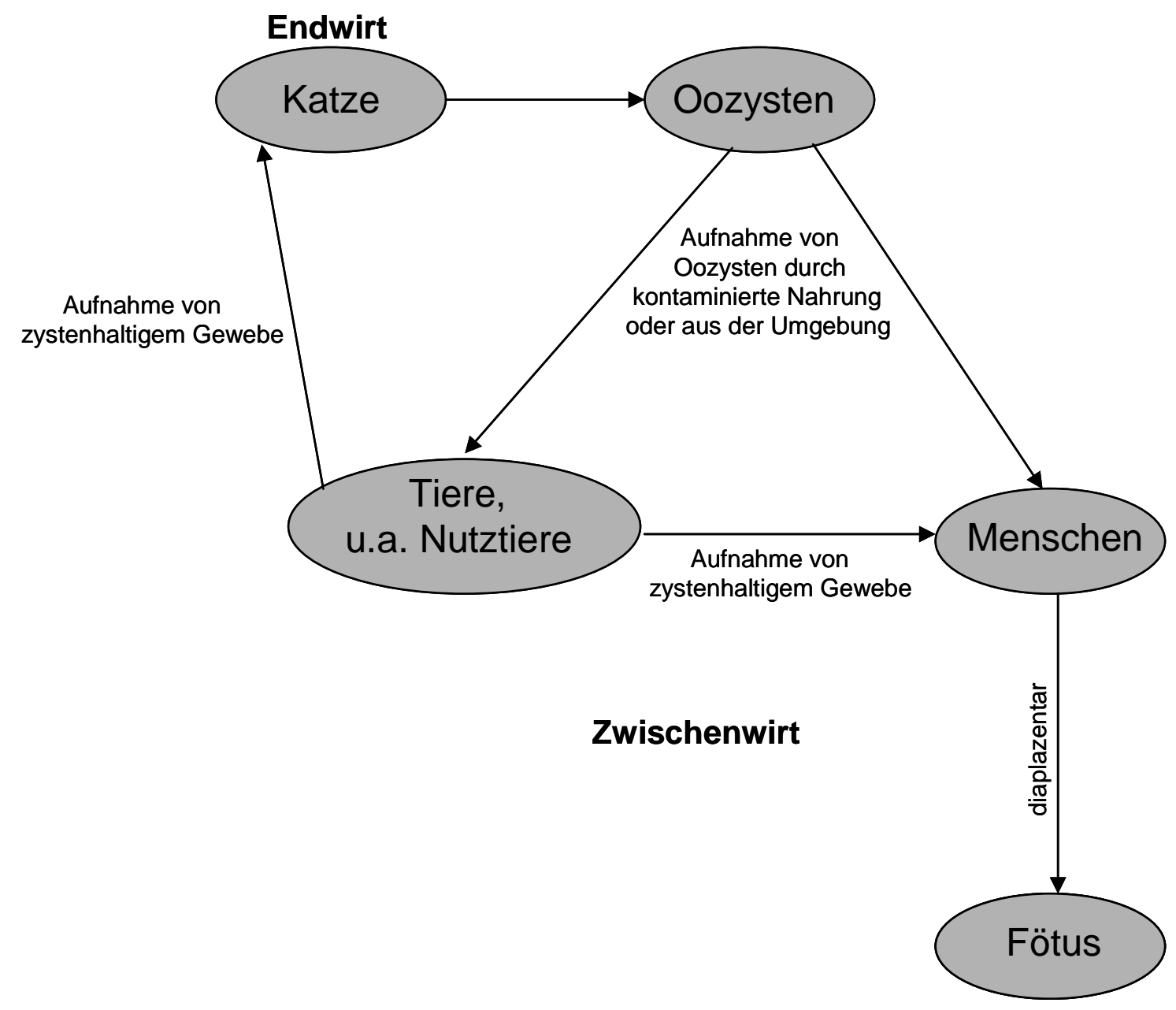




\section{3 Übertragung von T. gondii auf Mensch und Tier}

T. gondii ist weltweit verbreitet und kann ein breites Wirtsspektrum infizieren. Für sein Überleben und seine Ausbreitung in den verschiedenen Wirten hat der Parasit eine Vielzahl von Übertragungsmöglichkeiten entwickelt. Alle drei infektiösen Stadien (Tachyzoiten, Bradyzoiten und Oozysten) spielen durch unterschiedliche Übertragungswege eine Rolle als Infektionsquelle für Menschen und Tiere.

\subsubsection{Oozysten als Infektionsquelle}

Die mit dem Kot der Katze in die Umwelt ausgeschiedenen sporulierten Oozysten stellen eine potentielle Infektionsquelle für Menschen und andere Zwischenwirte dar, wobei die Übertragung horizontal durch Ingestion von Oozysten mit kontaminierten Lebensmitteln und Wasser oder Inhalation von Oozysten-haltigen Stäuben erfolgt. Nach Erstinfektion kann die Katze nach 3-10 Tagen mehr als 10 Millionen Oozysten ausscheiden, während bei einer erneuten Infektion der Katze eine Oozystenausscheidung selten ist (Groß 2004).

Oozysten zeichnen sich durch eine große Umweltresistenz aus und sind somit eine lange Zeit überlebensfähig. Darüber hinaus sind sie aufgrund ihrer Zystenwand sehr resistent gegen Desinfektionsmittel (Wainwright et al. 2007). Verschiedene Faktoren, wie z.B. Wind, Regen und Oberflächenwasser, können zur Verbreitung von Oozysten in der Umwelt beitragen. Dabei spielen auch Regenwürmer und koprophage Invertebraten eine Rolle (Tenter et al. 2000).

Durch Kontakt mit Oozysten-kontaminiertem Erdboden besteht eine Gefahr der Infektion von Nutztieren bei der Nahrungssuche, vor allem von Schafen, Ziegen und Hühnern (Vesco et al. 2007; Lehmann et al. 2006). Eine Studie in den Niederlanden zeigte, dass bei Freilandhaltung von Schweinen die Möglichkeit einer T. gondii im Vergleich zur Stallhaltung erhöht ist (Van der Giessen et al. 2007). Die hohe Seroprävalenz von bis zu $92 \%$ bei landwirtschaftlichen Nutztieren mit Weidegang in einigen Regionen der Erde deutet auf eine breite Umweltkontamination mit T. gondiiInfektion hin (Tenter et al. 2000). In Brasilien wurde die Existenz von Antikörpern gegen $T$. gondii bei $60 \%$ der sechs- bis achtjährigen Kinder mit der Ingestion von Oozysten aus der Umwelt verbunden (Bahia-Oliveira et al. 2001). 
Das Oozystenstadium des Parasiten hat vermutlich auch eine wichtige Bedeutung als Infektionsquelle für den Menschen, da die Übertragung durch den Verzehr von ungewaschenem, rohem Gemüse oder Obst, das erdnah angebaut wurde, erfolgen kann (Kapperud et al. 1996). Man kann auch durch den Kontakt mit Oozystenkontaminierter Erde (z. B. bei der Gartenarbeit) eine Infektion mit T. gondii bekommen. Darüber hinaus kann kontaminiertes Trinkwasser eine Infektionsquelle darstellen. Der weltweit größte Ausbruch einer akuten Toxoplasmose erfolgte im Jahr 1995 in Vancouver (Kanada), wobei sich 110 Personen mit Oozysten-kontaminiertem kommunalem Trinkwasser infizierten (Bowie 1997; Eng 1999). Ebenso konnte gezeigt werden, dass in Gebieten mit unbehandelten Trinkwasser oder geringen Hygienestandards Oozysten-kontaminiertes Trinkwasser eine wichtige Rolle bei der Infektion mit T. gondii spielt (Bahia- Oliveira et al. 2003; Ertrug et al. 2005; Sroka 2006; Heukelbach et al. 2007).

\subsubsection{Gewebezysten als Infektionsquelle}

Bradyzoiten-enthaltende Gewebezysten sind resistent gegenüber proteolytischen Enzymen (Dubey et al. 1998) und können bei $+4^{\circ} \mathrm{C}$ bis zu drei Wochen überleben. Durch Erhitzen auf mehr als $67^{\circ} \mathrm{C}$ oder durch Aufbewahrung bei mindestens $-12^{\circ} \mathrm{C}$ werden sie jedoch abgetötet. Die horizontale Übertragung von T. gondii auf den Menschen kann daher durch die orale Aufnahme von rohem oder nicht ausreichend erhitztem, zystenhaltigem Fleisch infizierter Nutztiere erfolgen. Aus einer europäischen Multi-Center-Studie geht hervor, dass 30-63\% der Toxoplasma-Infektionen durch den Verzehr von nicht genügend erhitztem Fleisch verursacht werden. Im Vergleich dazu werden nur 6-17\% der Infektionen auf den Kontakt mit kontaminierter Erde zurückgeführt (Cook et al. 2000).

Die Prävalenz von Toxoplasmen sowie die Anzahl von Zysten im Gewebe sind abhängig von der Tierart. Dabei wurde eine vergleichsweise große Anzahl von Gewebezysten in infizierten Schweinen, Schafen und Ziegen beobachtet, weniger jedoch bei Geflügel, Kaninchen, Pferden und Wildtieren. Darüber hinaus stellt eine hohe Seropositivität in einigen Nutztieren nicht unbedingt eine Infektionsgefahr für den Fleischverbraucher dar. Obwohl die Seroprävalenz von T. gondii in einigen Regionen der Erde bei Rindern mehr als 90\% beträgt, kommen Gewebezysten in dieser Tierart nur selten vor (Tenter et al. 2000; Dubey und Jones 2008). 
Die Bedeutung von rohem Fleisch als Risikofaktor für eine Infektion mit T. gondii hängt von unterschiedlichen Kultur- und Essgewohnheiten der Verbraucher sowie den geografischen Regionen und der Tierhaltung ab. In Europa und den USA kommt dem Schweinfleisch aufgrund der Häufigkeit des Verzehrs eine große Bedeutung bei der Übertragung der Infektion auf den Menschen zu. In Deutschland z.B. betrug der Konsum von Schweinefleisch im Jahr 2009 pro Kopf 39,0 kg/Jahr, im Vergleich zu $8,5 \mathrm{~kg} / \mathrm{Jahr}$ von Rind- und Kalbfleisch, 0,6 kg/Jahr pro Kopf von Schaf- und Ziegenfleisch und 11,0 kg/Jahr von Geflügelfleisch (nach Schätzung des Bundesmarktverbandes für Vieh und Fleisch). In Ländern wie Frankreich und Norwegen dagegen wurde beschrieben, dass der Verzehr von unzureichend gekochtem Lammfleisch ein höheres Risiko für Menschen darstellt als der Verzehr von Schweinefleisch (Kapperud et al. 1996; Baril et al. 1999).

Beschäftigte der Fleisch-verarbeitenden Lebensmittelindustrie wie z.B. Schlachthausangestellte, Metzger und Jäger sind voraussichtlich zusätzlich durch die Ausweidung und Fleischbehandlung gefährdet, sich mit T. gondii zu infizieren. So wurde in einer Studie in Ägypten (Ibrahim et al. 1997) und in einer anderen in Brasilien (Dias et al. 2005) sowie in China (Zhou et al. 2011) gezeigt, dass Schlachthausangestellte eine hohe Prävalenz von Antikörpern gegen T. gondii aufweisen. Dagegen konnte in einer Studie in Mexiko (Alvarado-Esquivel und Estrada-Martinez 2011) keine Korrelation zwischen der Beschäftigung mit rohem Fleisch und der T. gondiiSeropositivität gefunden werden. Der Grund für diese Unterschiede kann je nach geographischer Region, Kontrollgruppe, Verwendung von besseren hygienischen Bedingungen in den Schlachthäusern und Schutzmaßnahmen für die Schlachthausangestellten variieren.

\subsubsection{Tachyzoiten als Infektionsquelle}

Eine weitere wichtige Infektionsmöglichkeit ist die vertikale Übertragung von Tachyzoiten bei einer Erstinfektion in der Schwangerschaft über die Plazenta auf den Fötus. In Abhängigkeit vom Infektionszeitpunkt kann dies zu unterschiedlichen klinischen Symptomen führen. Tachyzoiten können außerhalb ihres Wirtes jedoch nicht überleben. Aus diesem Grund spielen sie epidemiologisch bei der horizontalen Übertragung eine untergeordnete Rolle. 
Es besteht jedoch das Risiko einer Infektion durch Tachyzoiten-enthaltende Milch. In der Milch einiger Zwischenwirte, wie z. B. Schafen, Ziegen und Rindern konnten Tachyzoiten nachgewiesen werden (Dubey und Beattie 1988). Zudem konnte eine akute Toxoplasmose durch den Konsum unpasteurisierter Ziegenmilch beim Menschen beobachtet werden (Skinner et al. 1990). Ebenso wurde eine Toxoplasmose bei einem gestillten Kleinkind beschrieben, dessen Mutter sich während der Stillzeit infiziert hatte (Bonametti et al. 1997). Die im Magen vorhandenen proteolytischen Enzyme sind zwar in der Lage, Tachyzoiten abzutöten, da sie bei Kleinkindern aber in geringeren Konzentrationen vorhanden sind, besteht bei ihnen ein erhöhtes Risiko einer durch orale Aufnahme von Tachyzoiten verursachten Toxoplasmose. Des Weiteren wurden Tachyzoiten im Sputum, Speichel, Urin, Tränen und Sperma von einigen Zwischenwirten entdeckt (Tenter et al. 2000).

Akzidentielle Infektionen mit Tachyzoiten sind auch durch Organtransplantation (z. B. Herz, Leber, Niere), Bluttransfusionen oder Laborunfälle möglich (Montoya und Liesenfeld 2004).

\subsection{Die medizinische Bedeutung von T. gondii}

Die Toxoplasmose ist eine der häufigsten, über die Nahrung übertragene parasitäre Krankheit. Welcher Infektionsweg epidemiologisch die größte Rolle spielt, ist nicht bekannt. Ungefähr ein Drittel der Weltbevölkerung hat Antikörper gegen den Parasiten (Tenter et al. 2000). Dabei nimmt die Seroprävalenz von T. gondii mit dem Lebensalter zu, ohne einen großen Unterschied zwischen den beiden Geschlechtern zu zeigen. In Deutschland nimmt die Seroprävalenz pro Lebensjahr um ca. $1 \%$ zu (Groß 2004). Außerdem variiert die Prävalenz zwischen den geographischen Regionen und den ethnischen Gruppen. In den USA und England beträgt die Seroprävalenz etwa 16-40\% während sie in Europa, Zentral- und Südamerika bei 50 - 80\% liegt (Dubey und Beattie 1988). Zudem konnten in Nord- und Südeuropa unterschiedliche Seroprävalenzen beobachtet werden. So liegt diese in den südlichen Ländern bei etwa 54\%, während sie in Nordschweden und Norwegen nur $5-10 \%$ beträgt (Evengard et al. 2001).

Die Infektion mit $T$. gondii verläuft bei immunkompetenten Patienten in der Regel asymptomatisch, wobei die Zysten im Gewebe lebenslang persistieren können, ohne dass der Patient die Infektion je bemerkt. Der Krankheitsgrad einer Toxoplasmose ist 
abhängig von der Virulenz des T. gondii-Stammes und der Anfälligkeit des Wirtes (Hill et al. 2005).

In ca. 10\% der Fälle zeigen infizierte Menschen milde Symptome, wie z.B. Fieber, Erschöpfung, Kopfschmerzen und die am häufigsten auftretenden Lymphknotenschwellungen, die bis zu 4-6 Monate andauern können (Montoya und Liesenfeld 2004). Auch eine okuläre Toxoplasmose kann nach Infektion von Immungesunden vorkommen. Lange Zeit ging man davon aus, dass eine Retinochorioiditis durch eine pränatale Infektion hervorgerufen wird (Lebech et al. 1999). Neuere Erkenntnisse bringen die okuläre Toxoplasmose jedoch hauptsächlich mit einer postnatalen Infektion in Verbindung (Gilbert und Stanford 2000; Holland 2003). Laut Holland (2003) haben in den USA ca. 2 \% der Immungesunden, die sich mit T. gondii infiziert haben, okuläre Symptome (meistens Retinochorioiditis) entwickelt. Retinochorioiditis kann nach akuter Toxoplasmose sowie auch nach Aktivierung einer latenten Infektion auftreten (Montoya und Remington 1996). Bei Immunkompetenten können aber auch sehr selten schwere Manifestationen wie Enzephalitis, Hepatitis oder Myokarditis vorkommen (Tenter et al. 2000).

Die Toxoplasmose stellt bei einer Primärinfektion während einer Schwangerschaft ein großes klinisches Problem dar, da in diesem Fall eine Gefährdung für den Fötus besteht. Dabei wird der Parasit über die Plazenta übertragen und kann zu schweren intrauterinen Schädigungen oder Spätfolgen führen. Eine unbehandelte Erstinfektion während der Schwangerschaft kann bei ca. 50\% der Frauen zu einer konnatalen Infektion führen, wobei die Inzidenz der pränatalen Infektion weltweit 0,12-2\% beträgt (Groß 2004).

Das Risiko der diaplazentaren Übertragung und die Möglichkeit der klinischen Manifestation beim Kind sind wesentlich vom Zeitpunkt der maternalen Infektion während der Schwangerschaft abhängig (Groß 2004). So ist das Risiko der Infektionsübertragung auf den Fötus im 1. Trimenon mit 10-15\% am geringsten und im 3. Trimenon mit 60-90\% am höchsten (Remington et al. 2006). Je früher jedoch eine Erstinfektion während einer Schwangerschaft auftritt, desto schwerer sind die klinischen Symptome. Zudem können Infektionen im 1. Trimenon zu einem Abort führen, während Infektionen im 2. Trimenon zu Gehirnschädigungen mit Hydrozephalus, intrazerebralen Verkalkungen und/oder Retinochorioiditis führen können. Die meisten Kinder, die kurz vor der Geburt infiziert werden, sind bei der Geburt asymp- 
tomatisch, aber ca. 80-90\% von innen können bis zum 20. Lebensjahr eine Retinochorioiditis entwickeln (Koppe et al. 1986).

Eine Toxoplasma-Infektion ist des Weiteren von großer Bedeutung bei immunsupprimierten Patienten. Dabei handelt es sich in der Regel um eine Reaktivierung der latenten Infektion, welche zu zerebraler oder systemischer Toxoplasmose führen kann. Gleichzeitig gehört die T. gondii-bedingte Enzephalitis zu den häufigsten klinischen Symptomen bei AIDS-Patienten (Luft et al. 1983). Dabei erhöht sich das

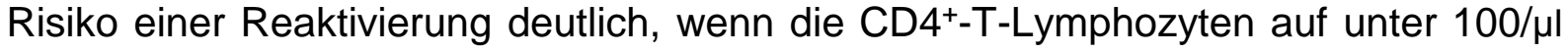
abnehmen. Etwa ein Drittel der HIV-Patienten, die IgG-Antikörper gegen T. gondii besitzen, entwickeln eine solche Toxoplasma-bedingte Enzephalitis (Walker und Zunt 2005), die somit eine der häufigsten Todesursachen bei AIDS-Patienten darstellt. In den USA sterben ungefähr 10\% und in Europa bis zu 30\% der AIDSPatienten an Toxoplasmose (Luft und Remington 1992). Allerdings ist infolge der Verwendung von hochaktiven antiretroviralen Therapien (HAART) T. gondiiassozierte Mortalität bei AIDS-Patienten deutlich gesunken (Samuel et al. 2002; Jones et al. 2002; Hooshyar et al. 2007).

Ebenso wurde eine schwere klinische Toxoplasmose bei Krebspatienten beobachtet, die unter einer immunsuppressiven Therapie standen oder eine Organtransplantation erhielten (Schaffner 2001).

\subsection{Diagnostik}

Die Diagnose einer Infektion mit T. gondii erfolgt entweder indirekt durch verschiedene serologische Verfahren oder direkt durch Nachweis des Parasiten mit Hilfe von Mausinokulation, Zellkultur oder Nachweis von DNA mittels der Polymerasekettenreaktion (PCR)-Technik aus unterschiedlichen Körperflüssigkeiten und Geweben (Montoya und Liesenfeld 2004).

Mit Hilfe von serologischen Verfahren kann zwischen akuten und chronischen Infektionen unterschieden werden. So lassen sich IgM-Antikörper nach einer Woche und IgG-Antikörper nach ca. 1-2 Wochen nach Infektion nachweisen. Nur IgGAntikörper können lebenslang nachgewiesen werden. Das Immunsystem des Patienten und auch die eingesetzte Untersuchungsmethode können Einfluss auf den Nachweis dieser Antikörper haben. 
Zu den serologischen Methoden gehört der Sabin-Feldman-Dye-Test, der im Jahr 1948 von Albert Sabin und Harry Feldman entwickelt wurde (Sabin und Feldman 1948). Der Test war ein wichtiges epidemiologisches Mittel zur Bestimmung der Prävalenz der Toxoplasma-Infektion und galt für Jahre als Gold-Standard zum Nachweis von T. gondii. Das Prinzip des Testes beruht auf der Verhinderung der Färbung lebender Toxoplasmen mit Methylenblau, wenn sich in Patientenserum spezifische Antikörper gegen T. gondii befinden. Aufgrund der Notwendigkeit lebender Toxoplasmen wird der Sabin-Feldman-Test zurzeit nur in wenigen Laboren verwendet.

Für die Toxoplasma-Diagnostik in der Humanmedizin werden heutzutage meist verschiedene Methoden verwendet wie z.B. der indirekte ImmunfluoreszenzAntikörper-Test (IFAT), der den Nachweis von IgG-, IgM-, und IgA-Antikörpern ermöglicht. Außerdem gibt es verschiedene Agglutinationstests wie z.B. den Hämagglutinationstest (HAT), den Latexagglutinationstest (LAT) und den direkten Agglutinationstest (DAT) zum Nachweis von T. gondii-spezifischen Antikörpern. Darüber hinaus ist der Enzym-linked-Immunosorbent-Assay (ELISA) eine häufig eingesetzte Methode, der ebenfalls den Nachweis von den verschiedenen spezifischen Antikörpern (IgG, IgM und $\lg A$ ) erlaubt.

Die erfolgreichste Methode für den direkten Erregernachweis stellt heutzutage die PCR dar, bei der T. gondii -spezifische Primer verwendet werden. So kann mittels PCR eine konnatale (Grover et al. 1990), okuläre (Montoya et al. 1999), zerebrale und disseminierte Toxoplasmose (Dupouy-Camet et al. 1993) diagnostiziert werden. Die pränatale Toxoplasmose wird mittels Ultraschalluntersuchung oder durch PCRAnalyse aus Fruchtwasser oder fetalem Blut nachgewiesen.

\subsection{Therapie und Prävention}

Eine Behandlung der asymptomatischen Infektionen bei Immunkompetenten ist in der Regel nicht erforderlich. Die Therapie erfolgt bei einer Erstinfektion im Verlauf der Schwangerschaft bis zur 16. Schwangerschaftswoche mit Spiramycin, gefolgt von einer Therapie bestehend aus Pyrimethamin und Sulfadiazin. Zudem wird zusätzlich Folinsäure verabreicht, um Schäden am Knochenmark zu vermeiden. Dabei kann diese Therapie in Kombination mit regelmäßigen Verlaufsuntersuchungen der Kinder zur Verminderung der plazentären Übertragung des Parasiten und des Krankheits- 
grades bei Neugeborenen führen (Groß 2004; Hotop et al. 2012). Eine ähnliche Behandlung mit den drei genannten Medikamenten ist für die konnatale und reaktivierte Toxoplasmose, bei einer Retinochorioiditis und einer Enzephalitis angezeigt (Montoya und Liesenfeld 2004). Eine Retinochorioiditis kann außerdem mit Clindamycin oder Cotrimoxazol therapiert werden (Groß 2004).

Um eine Infektionen mit T. gondii beim Menschen zu vermeiden, haben Präventionsmaßnahmen - besonders bei schwangeren Frauen und immmunsupprimierten Patienten - eine große Bedeutung. Dazu zählt, Fleisch vor dem Verzehr ausreichend zu erhitzen, die Hände nach dem Kontakt mit rohem Fleisch zu waschen, Gemüse und Obst gründlich zu waschen und Kontakt mit Katzen sowie mit Katzenkotkontaminierter Erde zu vermeiden.

\subsection{Die Prävalenz von T. gondii im Schwein}

Die Aufnahme von Toxoplasma-Zysten durch Verzehr von rohem oder unzureichend erhitztem Fleisch oder Fleischprodukten verschiedener Nutztiere (besonders Schweine, Schafe und Geflügel) stellt eine bedeutende Infektionsquelle mit T. gondii für den Menschen dar. In Deutschland z.B. haben Schweine und Hühner vermutlich eine große Bedeutung in der Übertragung des Erregers auf den Menschen.

Die Toxoplasmose bei Schweinen tritt weltweit auf. In vielen Ländern wird bevorzugt Schweinefleisch verzehrt und in Europa und den USA wird kontaminiertes Schweinefleisch daher als Hauptquelle für Infektion des Menschen mit T. gondii angesehen (Tenter et al. 2000). Schweine sind als Fleischlieferanten in verschiedenen Ländern der Erde von großer wirtschaftlicher Bedeutung. Die Prävalenz von T. gondii bei Schweinen ist abhängig von verschiedenen Faktoren wie z.B. den Hygienemaßnahmen, der Haltung und dem Alter der Tiere. Aufgrund von wesentlichen Änderungen in den landwirtschaftlichen Produktionsanlagen, die unter besseren hygienischen Verhältnissen arbeiten und Katzen und Kleinnager aus der Schweinehaltung fernhalten, wurde die Toxoplasma-Infektion der Schweine in den letzten Jahrzehnten gesenkt. Untersuchungen in verschiedenen Ländern zeigten, dass die Seroprävalenz von T. gondii bei Mastschweinen aus Intensivhaltungsbetrieben unter $10 \%$ beträgt (Tenter et al. 2000).

Schweine in Freilandhaltung haben aufgrund des stärkeren Kontaktes mit Toxoplasma-Oozysten in der Umwelt ein höheres Risiko, sich mit dem Parasiten zu infizieren 
im Vergleich zu intensiv gehaltenen Tieren. In einer niederländischen Studie von Kijlstra et al. (2004) wurden 1916 Schweineseren mittels Latexagglutinationstest (LAT) und Immunofluoreszenz-Antikörper-Test (IFAT) getestet. Diese Untersuchungen ergaben, dass 1,2\% der Tiere aus ökologischer Haltung bzw. 4,7\% der Tiere aus Freilandhaltung positiv reagierten, während alle Tiere aus Intensivhaltungsbetrieben seronegativ waren. In Deutschland dagegen waren alle Schweine aus ökologischer Haltung seronegativ, während Schweine aus Freilandhaltung eine Seroprävalenz von 15,2\% aufwiesen (Schulzig und Fehlhaber 2005). Zudem konnten Weigel et al. (1995) zeigen, dass die Seroprävalenz abhängig vom Alter der Tiere ist. So war die Infektionsrate in Illinois (USA) bei Mastschweinen mit 3,1\% deutlich geringer gegenüber $20,8 \%$ bei den Zuchtsauen. In Deutschland zeigte eine Studie ähnliche Ergebnisse: hier betrug die Prävalenz bei Mastschweinen 3,9\% und bei Sauen 31,6\% (Ludewig et al. 2007).

Obwohl die Umstellung zu modernen Produktionsanlagen mit höherem Hygienestandard die Infektionen mit T. gondii bei Schweinen reduziert hat, führt die zunehmende Tendenz zu tierfreundlichen Haltungsformen zu einem erneuten Anstieg der Toxoplasmoseprävalenz bei Schweinen (Kijlstra et al. 2004; van der Giessen et al. 2007). Ein häufiger Übertragungsweg der Infektion mit T. gondii auf den Menschen in vielen Ländern ist der Verzehr von rohem oder ungenügend erhitztem Schweinfleisch oder den daraus hergestellten Produkten. Die Verteilung der Gewebezysten sowie die Zystenanzahl in jedem Gewebe spielen auch eine Rolle bei der Übertragung der Infektion. Dabei ist vor allem von Bedeutung, welche Organe am häufigsten Gewebezysten enthalten und ob diese Organe essbar sind oder nicht. Nach einer Infektion bilden sich im Zuge der Aktivierung des Immunsystems Gewebezysten im Wirt aus. In welche Gewebe sich der Parasit ausbreitet und welche Organe bevorzugt befallen werden, ist abhängig von der Tierart. Dubey (2009) konnte zeigen, dass lebende Parasiten bei Schweinen am häufigsten aus dem Gehirn, dem Zungenmuskel, dem Herz und dem Zwerchfellmuskel isoliert werden konnten. Eine Studie von Dubey (1988) zur Persistenz und Verteilung des Erregers in Geweben experimentell mit Oozysten infizierter Schweine zeigte, dass der Parasit im Gewebe von Schweinen bis zu 875 Tage nach der Infektion persistieren konnte. Die Untersuchungen ergaben weiterhin, dass T. gondii bei 14 von 16 Tieren nachgewiesen werden konnte. Dabei wurde T. gondii bei 11 Tieren im Herzen, bei 10 Tieren in der Zunge, bei 12 Tieren im Gehirn und bei 6 Tieren im Zwerchfellmuskel nachgewiesen. Bei 5 von 16 
Schweinen wurden lebende Toxoplasmen aus kommerziell vermarkteten Fleischstücken (Schulter, Schwanz, Schälrippchen, Keule) isoliert (Dubey 1988). Des Weiteren konnte lebende Parasiten aus 13 von 149 Schweinewürsten isoliert werden (Dias et al. 2005). Zudem konnte der Erreger in Japan aus 57 von 101 Lymphknoten chronisch infizierter Schweine isoliert werden (Zakimi et al. 2006).

\subsection{Die Prävalenz von T. gondii im Huhn}

Hühner werden in vielen Ländern als eine bedeutende Quelle für Humaninfektionen mit T. gondii angesehen. Weil sie auch eine wesentliche Infektionsquelle für Katzen darstellen, die die umweltresistenten Oozysten ausscheiden, spielen Hühner eine wichtige Rolle in der Epidemiologie der Infektion von T. gondii (Dubey 2010).

Weltweit wurde die Toxoplasmose des Huhns sowohl bei Freilandhühnern als auch bei Käfighaltung untersucht. Dabei hat die Infektion bei Freilandhaltung eine große Bedeutung aufgrund der Essgewohnheiten der Hühner. Hühner nehmen die Nahrung vom Boden auf, was als Indikator für die Kontamination von Böden mit T. gondiiOozysten verwendet werden kann (Dubey 2010). In vielen Ländern wiesen Studien zur Seroprävalenz bei Freilandhühnern eine hohe Infektionsrate nach; so lag diese z.B. in Brasilien bei 39\% im Jahr 2002 (Dubey et al. 2002) und im Jahr 2006 sogar bei 66\% (Dubey et al. 2006; Aigner et al. 2010). In einer weiteren Studie konnten die Autoren mittels modifiziertem Agglutinationstest (MAT) Antikörper gegen Toxoplasma gondii bei 129 (65\%) von 198 Freilandhühnern nachweisen, wobei mittels Bioassay der Erreger im Gewebe 86 von 198 Hühnern untersucht wurde und bei 61 (70,9\%) davon im Fleisch nachgewiesen werden konnte (da Silva et al. 2003).

Neben dem serologischen Nachweis von T. gondii bei Hühnern wurde teilweise auch die Infektionsverteilung im Gewebe bestimmt. Außerdem wurde ermittelt, welche Organe vom Parasiten bevorzugt besiedelt wurden. Dabei weisen mehrere Studien darauf hin, dass das Herz und das Gehirn zu den Organen gehören, die bevorzugt von T. gondii besiedelt werden (Dubey et al. 1993; Aigner et al. 2010; Yan et al. 2010).

In einem Übersichtsartikel von Dubey (2010) wurden Ergebnisse aus verschiedenen Ländern in Südamerika, den USA und Portugal zusammengefasst, die die Verteilung der lebenden Parasiten in Gewebe natürlich infizierter Freilandhühner darstellten. Insgesamt wurden dabei 149 Tiere durch Bioassays in der Maus untersucht, wobei 
das Herz mit 89,5\% am häufigsten betroffen war, gefolgt vom Gehirn mit 49,2\% und dem Oberschenkel mit 44,1\%. Der Brustmuskel war mit 18,6\% am wenigsten betroffen. Diese Erkenntnisse sind insofern interessant, weil T. gondii auf Basis von Studien mit Nagern als neurotroper Parasit gilt.

Im Vergleich zu Freilandhaltung ist die Prävalenz von lebenden Toxoplasmen bei Hühnern aus Käfighaltung oder Schlachthöfen niedriger und somit das Risiko einer Infektion durch den Verzehr dieses Fleischs ebenfalls geringer (Dubey 2010).

Obwohl in einigen Studien erwähnt wurde, dass T. gondii aus Organen wie Eierstock und Eileiter natürlich infizierter Hühner isoliert werden konnte (Jacobs und Melton 1966; Foster et al. 1969), ist die Wahrscheinlichkeit einer Toxoplasma-Infektion durch den Verzehr von rohen Hühnereiern eher gering.

\subsection{Ziel der Arbeit}

Die Toxoplasmose ist eine der wichtigsten Lebensmittel-übertragenen Infektionskrankheiten. Der Verzehr von rohem oder unzureichend erhitztem ToxoplasmaZysten-haltigem Fleisch von Nutztieren spielt eine große Rolle bei der Übertragung des Erregers auf den Menschen. In Deutschland könnten Schwein und Huhn dabei die größte Bedeutung besitzen. Die Anzahl von T. gondii-Zysten und die Prädilektionsstellen des Erregers im Wirtsgewebe variieren jedoch von Tierart zu Tierart. Der Erreger scheint aber besonderes häufig im Zentralnervensystem (ZNS), Skelettmuskulatur, Auge und Herz zu persistieren. Allerdings ist die Persistenz von Toxoplasma in Muskulaturgewebe (besonderes Skelettmuskulatur) in infizierten Schweinen und Hühnern wenig untersucht. Deshalb war das Ziel dieser Arbeit, die Verteilung von Toxoplasma gondii in verschiedenen Geweben von infizierten Schweinen und Hühnern zu bestimmen. Dazu sollten Gewebeproben von experimentell mit T. gondii infizierten Tieren mittels quantitativer PCR auf Parasiten-DNA untersucht werden und die Parasitenbelastung quantifiziert werden. Auch sollte eine Methode zur Bestimmung der Viabilität von Parasiten in Wirtsgewebe etabliert werden. Bei diesen Untersuchungen war besonderes die Bedeutung von Skelettmuskulatur von Schweinen und Hühnern für die Persistenz des Parasiten von Interesse. Dadurch sollte ein Beitrag geleistet werden, die Bedeutung von Toxoplasma-Persistenz in Skelettmuskulatur von Schweinen und Hühnern zu bestimmen. 


\section{Material und Methoden}

\subsection{Material}

\subsubsection{Geräte}

Agarosegelelektrophorese

Geldokumentationsanlage

LightCycler ॥

Mikroskope

Nano-Drop

Pipetten

Thermocycler

Thermomixer

Vortexer

Waagen

Zählkammer

Zentrifugen
Keutz Labortechnik, Reiskirchen

BioDocll, Biometra, Göttingen

Roche, Mannheim

Axiostar plus, Zeiss

Model DM IL, Leica, Wetzlar

Modell1000, Thermo Scientific,

Schwerte

Reference, Eppendorf, Hamburg

Modell T3, Biometra, Göttingen

Modell compact, Eppendorf, Hamburg

Reax Top, Heidolph, Kelheim

LP6200 S, Sartorius, Göttingen

CP224 S, Sartorius, Göttingen

Neubauer, Roth, Karlsruhe

Modell 5424, Eppendorf, Hamburg

IK 15, Sigma, Osterode am Harz

Megafuge 2.0, Heraeus, Hanau

Megafuge 2.0 RS, Heraeus, Hanau

\subsubsection{T. gondii}

NTE-Stamm (Typ II)

DX-Stamm (Typ II) maus-avirulent

maus-avirulent
(Groß et al.1991)

(Dzitko et al. 2006) 


\subsubsection{Tiergewebe}

NMRI-Maus (Mus musculus) eigene Zucht, Institut für Medizinische Mikrobiologie, Göttingen

Schwein (Sus scrofa domestica) Institut für Parasitologie, Tierärztliche Hochschule, Hannover

Huhn (Gallina gallus domesticus) Institut für Parasitologie, Tierärztliche Hochschule, Hannover

\subsubsection{Genomische DNA-Präparationen von Coccidia-Parasiten}

Neospora caninum Institut für Parasitologie, Tierärztliche Hochschule, Hannover Sarcocystis gigantea Institut für Parasitologie, Tierärztliche Hochschule, Hannover Besnoitia besnoiti Institut für Parasitologie, Tierärztliche Hochschule, Hannover Neospora caninum Institut für Epidemiologie, Wusterhausen Besnoitia besnoiti Institut für Epidemiologie, Wusterhausen Hammondia hammondi, Institut für Epidemiologie, Wusterhausen Isospora canis Institut für Epidemiologie, Wusterhausen Isospora felis Institut für Epidemiologie, Wusterhausen Toxoplasma gondii Institut für medizinische Mikrobiologie, Göttingen

\subsubsection{Kits}

Genomische DNA-Isolierung

QIA Amp DNA Mini Kit

Qiagen, Hilden

RNA-Isolierung

Gen Elute Mammalian Total

Sigma-Aldrich, München

RNA Mini Kit

\section{Reverse Transkription}

Sensiscript Reverse Transcriptase

Qiagen, Hilden

\section{Real-time PCR-Kit}

LightCycler FastStart DNA

Roche, Mannheim

Masterplus SYBR Green I Kit 


\section{DNA-Aufreinigung}

QIAquick PCR Purification Kit

Qiagen, Hilden

\subsubsection{Primer}

Die Sequenzen für die PCR-Primer-Paare wurden aus der Literatur ausgewählt und von der Firma Sigma-Aldrich bezogen. Vor Gebrauch wurden sie mit $\mathrm{H}_{2} \mathrm{O}$-Bidest in einer Konzentration von $50 \mu \mathrm{M}$ gelöst, aliquotiert und bei $-20^{\circ} \mathrm{C}$ aufbewahrt. Folgende Primer wurden in dieser Arbeit eingesetzt:

Nachweis des 529-bp-Fragments von T. gondii

\begin{tabular}{lll}
\hline Bezeichnung & Sequenz 5' $\rightarrow 3^{\prime}$ & Referenzen \\
\hline Tox09_for & AGGAGAGATATCAGGACTGTAG & Reischl et al. 2003 \\
Tox011_rev & GCGTCGTCTCGTCTAGATCG & \\
Tox04_for & CGCTGCAGGGAGGAAGACGAAAGTTG & Homan et al.1999 \\
Tox05_rev & CGCTGCAGACACAGTGCATCTGGATT &
\end{tabular}

Nachweis des B1-Gens von T.gondii

\begin{tabular}{lll}
\hline Bezeichnung & Sequenz 5' $\rightarrow 3^{\prime}$ & Referenzen \\
\hline Tg1_for & AAAAATGTGGGAATGAAAGAG & Jalal et al. 2004 \\
Tg2_rev & ACGAATCAACGGAACTGTAAT & \\
Tg.nested1_for & CGCTAATGTGTTTGCATAGG & Jalal et al. 2004 \\
Tg.nested2_rev & GGCACGTCTCTTGTTCTTCT &
\end{tabular}

Nachweis des universellen Coccidia-Gens „small-subunit rRNA"

\begin{tabular}{lll}
\hline Bezeichnung & Sequenz $5^{\prime} \rightarrow 3^{\prime}$ & Referenzen \\
\hline Coc1_for & AAGTATAAGCTTTTATACGGCT & Schares et al. 2008 \\
Coc2_rev & CACTGCCACGGTAGTCCAATAC &
\end{tabular}

Nachweis des Actin-Gens von T. gondii

\begin{tabular}{lll}
\hline Bezeichnung & Sequenz $5^{\prime} \rightarrow 3^{\prime}$ & Referenzen \\
\hline TgActin_for & TGGCAACGAGCGATTCCGCTG & $\begin{array}{l}\text { Lüder, persönliche } \\
\text { Mittelung }\end{array}$ \\
TgActin_rev & GTTCCTTGGTCAGCCTCTCGCC &
\end{tabular}


Nachweis des Sag1-Gens von T. gondii

\begin{tabular}{lll}
\hline Bezeichnung & Sequenz 5' $\rightarrow 3^{\prime}$ & Referenzen \\
\hline sag1_for & ATCGCCTGAGAAGCATCACTG & Fux et al. 2007 \\
sag1_rev & CGAAAATGGAAACGTGACTGG &
\end{tabular}

Nachweis des Bag1-Gens von T. gondii

\begin{tabular}{lll}
\hline Bezeichnung & Sequenz 5' $\rightarrow$ 3' & Referenzen \\
\hline bag1_for & GACGTGGAGTTCGACAGCAAA & Fux et al. 2007 \\
bag1_rev & ATGGCTCCGTTGTCGACTTCT &
\end{tabular}

\subsubsection{Chemikalien und Reagenzien}

Substanz

Agarose

dNTPs

Ethidiumbromid

GeneRuler 1kb DNA-Ladder

PBS

RNasin

Taq-Polymerase
Bezugsquelle/Ort

Roth/Karlsruhe

Roche, Mannheim

Sigma / Deisenhofen

MBI Fermentas, St. Leon-Rot

Biochrom, Berlin

Promega, Medison

Roche, Mannheim 


\subsection{Methoden}

\subsubsection{Experimentelle Infektion von Schweinen und Hühnern mit T. gondii und Gewinnung von Gewebeproben}

Die Infektion der Schweine und Hühner, Gewinnung und Untersuchung der Seren, Töten der Tiere und Gewinnung von Gewebeproben wurden im Institut für Parasitologie, Tierärztliche Hochschule Hannover (Arbeitsgruppe von Prof. A. Tenter) durchgeführt. Dort wurden die Tiere oral mit verschiedenen Infektionsdosen von Toxoplasma Oozysten (DX-Stamm, Typ II) experimentell infiziert.

Für die vorliegende Arbeit wurden im ersten Infektionsversuch 8 Hühner verwendet, die mit verschiedenen Infektionsdosen von Toxoplasma Oozysten infiziert wurden, wovon 2 Hühner mit 1 Million Oozysten, 2 Hühner mit 100.000 Oozysten, 2 Hühner mit 10.000 Oozysten und 2 Hühner mit 1.000 Oozysten oral infiziert wurden.

Im zweiten Infektionsversuch wurden 12 Tiere verwendet, davon waren 4 Hühner mit 10 Million Oozysten, 4 Hühner mit 1 Million Oozysten, 2 Hühner mit 100.000 Oozysten und 2 Hühner mit 10.000 Oozysten oral infiziert. Als Negativkontrolle wurden 4 Hühner (K1, K2, K3 und K4) verwendet, die nicht infiziert wurden.

Um Toxoplasma gondii DNA im Gewebe der infizierten Hühner nachzuweisen, wurden die Tiere 49 Tage (Hühner des ersten Infektionsversuchs) bzw. 86 Tage (Hühner des zweiten Infektionsversuchs) nach der Infektion dekapitiert, präpariert und jeweils mehrere Gewebeproben von Herz, Brustmuskel, Oberschenkelmuskel und Gehirn von jedem Huhn gewonnen. Alle Proben wurden mit dem Skalpell und der Pinzette zerkleinert, in flüssigem Stickstoff schockgefroren und anschließend bei $-80^{\circ} \mathrm{C}$ oder in flüssigem Stickstoff gelagert.

Für die Versuche mit experimentell infizierten Schweinen wurden 11 Tiere verwendet, wovon 10 infiziert und 1 nicht infiziert war (Negativkontrolle: Schwein Nr.19). Dabei wurden 4 Schweine mit 1 Million Toxoplasma Oozysten, 3 mit 100.000 Oozysten und 3 mit 1.000 Oozysten oral infiziert. 110 Tage nach der Infektion wurden die Tiere durch Kopfschuss getötet und jeweils mehrere Gewebeproben von Herz, Oberschenkelmuskulatur, Zunge, Bauchmuskulatur, Vorderbeinmuskel und Gehirn gewonnen. Gewebeproben der Schweine wurden wie bei Hühnern gelagert.

Für die serologischen Untersuchungen der Tiere wurden Vollblutproben an unterschiedlichen Tagen nach Infektion bis zum Schlachttag abgenommen, zentrifugiert, 
Seren gewonnen und Antikörpertiter gegen T. gondii bestimmt. Bei Schweinen wurden die Seren mittels Enzym-linked-Immunosorbent-Assay (ELISA) auf spezifische Antikörper gegen Toxoplasma untersucht. Die Hühnerseren wurden mit Hilfe des Direktagglutinationstests (Toxoscreen DA von BioMerieux) untersucht, der spezifische Toxoplasma-Antikörper ( $\lg G$ ) im untersuchten Serum durch Agglutination mit dem im Test verwendeten Formalin-fixierten T. gondii-Antigen nachweist.

\subsubsection{Zellkultur von T. gondii und Parasitenisolierung}

T. gondii-Tachyzoiten des NTE-Stammes wurden in murinen L929-Fibroblasten vermehrt. Die Kultur erfolgte in 12-Loch-Zellkulturschalen, wobei Suspensionen von Wirtszellen und Toxoplasmen in unterschiedlichen Verhältnissen gemischt wurden. Als Nährmedium wurde je Loch etwa 1,5 ml Roswell Park Memorial Institut Medium 1640 (RPMI), mit 1\% foetalem Kälberserum (FCS), $100 \mathrm{U} / \mathrm{ml}$ Penicillin und 100 Mg/ml Streptomycin zugegeben. Zellkulturen wurden bei $37^{\circ} \mathrm{C}, 5 \% \mathrm{CO}_{2}$ und gesättigter Wasserdampfatmosphäre inkubiert.

Für Versuche mit Tachyzoiten wurden diese nach Lyse der Wirtszellen aus Zellkulturen isoliert. Durch Zentrifugieren bei 34 x g für 5 min wurden die Wirtszellen von den Parasiten abgetrennt und daraufhin die Toxoplasmen aus dem Überstand bei $1300 \times \mathrm{g}$ für $10 \mathrm{~min}$ abzentrifugiert. Das Pellet wurde mit $10 \mathrm{ml}$ Phosphat-gepufferter Kochsalzlösung (PBS-Puffer) gewaschen und erneut bei $1300 \times \mathrm{g}$ für 10 min zentrifugiert. Anschließend wurden die isolierten Toxoplasmen in einer NeubauerZählkammer ausgezählt, danach wurden verschiedenen Toxoplasma-Mengen in PBS-Puffer suspendiert und bis zur Verarbeitung bei $-20^{\circ} \mathrm{C}$ gelagert.

\subsubsection{Gewinnung von Mausgewebe}

Nicht infizierte NMRI-Mäuse wurden mit Hilfe von $\mathrm{CO}_{2}$ getötet, präpariert und Gewebe wie Gehirn und Oberschenkelmuskulatur entnommen. Diese wurden mit dem Skalpell zerkleinert und in Portionen zu 25 mg abgewogen. Anschließend wurde das Mausmuskelgewebe und Hirngewebe mit den bereits vorbereiteten, aufgetauten Toxoplasmen in Reaktionsgefäße überführt. Diese Proben (T. gondii und Mausgewebe) wurden bis zur DNA-Aufreinigung bei $-20^{\circ} \mathrm{C}$ gelagert. 


\subsubsection{Etablierung einer Standardkurve für quantitative PCR}

Zur Quantifizierung der Parasiten mittels quantitativer PCR wurden einerseits isolierte Toxoplasmen ohne Gewebe und andererseits inokuliertes Mausgewebe mit verschiedenen Toxoplasma-Mengen verwendet.

\subsubsection{Isolierung genomischer DNA}

Am Tag der Bearbeitung wurden die Gewebeproben von Schwein und Huhn nach dem Auftauen mit dem Skalpell zerkleinert, in Portionen zu $25 \mathrm{mg}$ abgewogen und danach in Reaktionsgefäße überführt.

Die Aufbereitung der abgewogenen Proben (Tiergewebe/ inokulierte Mausgewebe mit Toxoplasmen, isolierte Toxoplasmen) erfolgte mit Hilfe des QIA Amp ${ }^{R}$ DNA Mini Kits (Qiagen) nach Angabe des Herstellers zur DNA-Extraktion aus Geweben. Hierfür wurden $180 \mu \mathrm{l}$ ATL-Puffer und $20 \mu \mathrm{l}$ Proteinase K-Lösung zu den abgewogenen Proben gegeben, gevortext und bei $56^{\circ} \mathrm{C}$ im Thermomixer unter dauerhaftem Schütteln inkubiert. Nach vollständiger Lyse wurden $200 \mu \mathrm{l}$ AL-Puffer zugesetzt und bei $70^{\circ} \mathrm{C}$ für $10 \mathrm{~min}$ inkubiert, danach wurden $200 \mu \mathrm{l}$ Ethanol (96-100\%) zu dem Gemisch gegeben. Anschließend wurde die DNA an eine QIAmp Spin-Säule durch Zentrifugation bei $6.000 \times \mathrm{g}$ für 1 min gebunden. Nach mehreren Waschschritten wurde die DNA mit $200 \mu \mathrm{l}$ AE-Puffer, Inkubation bei Raumtemperatur für 1 min und Zentrifugation bei $6.000 \times \mathrm{g}$ für $1 \mathrm{~min}$ eluiert. Anschließend wurde die isolierte DNA für real-time $\mathrm{PCR}$ eingesetzt oder bei $-20^{\circ} \mathrm{C}$ gelagert.

\subsubsection{RNA-Isolierung}

Die RNA wurde aus Gewebe bzw. Toxoplasmen mittels des GenElute ${ }^{T M}$ Mammalian Total RNA Miniprep Kits (Sigma) nach Angaben des Herstellers isoliert. Für die RNAIsolierung aus in Zellkultur gehaltenen Toxoplasmen wurden diese zunächst bei $3000 \times \mathrm{g}$ für 5 min zentrifugiert. Anschließend wurden zum Pellet $250 \mu$ l Lysepuffer mit $10 \mu \mathrm{l} / \mathrm{ml}$ 2-Mercaptoethanol gegeben und gemischt. Bei RNA-Isolierung aus Gewebe wurden diese mit $300 \mu \mathrm{l}$ Lysepuffer mit $10 \mu \mathrm{l} / \mathrm{ml}$ 2-Mercaptoethanol homogenisiert. Zur vollständigen Lyse wurden $590 \mu \mathrm{l}$ RNase-freies Wasser mit $10 \mu \mathrm{l}$ Proteinase K-Lösung zugesetzt und bei $55^{\circ} \mathrm{C}$ für $30 \mathrm{~min}$ inkubiert. Anschließend 
wurde das Lysat (Toxoplasmen, Gewebe) in eine blaue Filtratsäule überführt und für 2 min bei 14.000 x g zentrifugiert. Zum Filtrat wurde Ethanol (Toxoplasmen: $250 \mu \mathrm{l}$ 70\%; Gewebe: 450 l 95-100\%) gegeben und gemischt. Die Lysat/Ethanol-Mischung wurde auf eine Nukleinsäure-bindende Säule übertragen, $1 \mathrm{~min}$ bei $14.000 \times \mathrm{g}$ zentrifugiert und der Durchfluss verworfen. Danach wurde $500 \mu$ l Waschpuffer 1 auf die Bindesäule gegeben und 1 min bei 14.000 x g zentrifugiert. Die Bindesäule wurde in neues Reaktionsgefäß überführt, $500 \mu \mathrm{l}$ Waschpuffer 2 auf die Säule gegeben und 1 min bei 14.000 x g zentrifugiert. Der Durchfluss wurde verworfen und der Waschschritt mit Waschpuffer 2 wurde wiederholt. Zur Entfernung von möglichen Ethanolrückständen erfolgte eine erneute Zentrifugation bei $14.000 \mathrm{Xg}$ für $1 \mathrm{~min}$. Anschließend wurde die Bindesäule in neues Reaktionsgefäß überführt und die RNA mit $50 \mu$ l Elutionspuffer und Zentrifugation bei $14.000 \times \mathrm{g}$ für 1 min eluiert.

Die RNA-Konzentration wurde mit Hilfe des Nano Drop Photospektrometers bestimmt und bis zum Einsatz bei $-80^{\circ} \mathrm{C}$ gelagert.

\subsubsection{Reverse Transkription}

Die isolierte RNA wurde mittels des Sensiscript Reverse Transkription Kits (Qiagen) in cDNA umgeschrieben. Die RT-Lösungen und die RNA-Proben wurden auf Eis nach dem folgenden Schema pipettiert, gemischt und bei $37^{\circ} \mathrm{C}$ für 90 min inkubiert. Anschließend wurde die resultierende cDNA mittels des PCR Purification Kits (Qiagen) gereinigt und bis zur weiteren Verwendung bei $-20^{\circ} \mathrm{C}$ gelagert.

$\begin{array}{ll}2 \mu \mathrm{l} & 10 \times \text { RT-Puffer } \\ 2 \mu \mathrm{l} & \text { dNTPs, } 5 \mathrm{mM} \text { pro dNTP } \\ 0,4 \mu \mathrm{l} & \text { Oligo-dT-Primer } 50 \mu \mathrm{M} \\ 1 \mu \mathrm{l} & \text { RNasin } 10 \mathrm{U} / \mu \mathrm{l} \\ 1 \mu \mathrm{l} & \text { Sensiscript Reverse Transkriptase } \\ 50 \mathrm{ng} & \text { RNA-Template } \\ \text { ad } 20 \mu \mathrm{l} & \text { RNase-freies Wasser }\end{array}$




\subsubsection{Quantitative real-tim Polymerasekettenreaktion}

\subsubsection{Prinzip}

Das Prinzip der konventionellen Polymerasekettenreaktion (PCR) beruht auf der Amplifikation eines definierten DNA-Abschnittes. Der PCR-Prozess besteht aus mehreren Zyklen und jeder Zyklus enthält drei Reaktionsschritte. Im ersten Schritt (Denaturierung) wird der DNA-Doppelstrang durch Erhitzen in Einzelstränge getrennt. Die spezifische Primer lagern sich im zweiten Schritt (Annealing) durch Absenken der Temperatur an die DNA-Einzelstränge an. Im dritten Schritt wird die Temperatur erhöht und die hitzestabile Taq-Polymerase verlängert die Primersequenzen, wodurch der DNA-Abschnitt verdoppelt wird. Durch Wiederholung dieser drei Schritte verdoppelt sich idealerweise die Kopienanzahl des amplifizierten, definierten DNA-Abschnitts bei jedem Zyklus.

Die quantitative real-time PCR ist eine Methode, die auf dem Prinzip der konventionellen (PCR) beruht. Dabei kombiniert diese Technologie die DNA-Amplifikation mit der Quantifizierung des Produktes mit Hilfe von Fluoreszenzfarbstoffen wie SYBR Green in einem einzigen Reaktionsgefäß.

Die Fluoreszenz nimmt proportional mit der Menge der PCR-Produkte zu. Am Anfang des PCR-Laufs ist die Fluoreszenz meist nicht nachweisbar, weil die Templatekonzentration noch gering ist. Der PCR-Zyklus, an dem das Fluoreszenzsignal signifikant steigt, stellt den so genannten Crossing Point (CT-Wert) dar, am Ende des Laufs wird anhand der erhaltenen Fluoreszenzsignale (CT-Werte) die Quantifizierung in der exponentiellen Phase der PCR vorgenommen. Nur in der exponentiellen Phase ist eine korrekte Quantifizierung möglich, weil während dieser Phase optimale Reaktionsbedingungen herrschen und keine limitierenden Faktoren vorhanden sind.

Zusätzlich können bekannte Templatemengen amplifiziert und daraus eine Standardkurve erstellt werden, anhand derer die gesuchten Templatekonzentration bestimmt werden kann.

In dieser Arbeit wurde die quantitative real-time PCR unter anderem genutzt, um Toxoplasma-DNA im Gewebe von experimentell infizierten Schweinen und Hühnern nachzuweisen und anhand einer Standardkurve zu quantifizieren. 


\subsubsection{Durchführung der real-time PCR}

Für Nachweis und Quantifizierung von T. gondii-DNA in isolierter Parasiten oder Gewebeproben wurde das 529-bp-repetitive DNA-Fragmente durch real-time PCRTechnologie im LightCycler nachgewiesen. Außerdem wurde auch mittels real-time PCR Coccidia-DNA, cDNA von T. gondii in Gewebeproben oder isolierten Parasiten auf Basis der Gene Sag1, Bag1 und $\beta$-actin nachgewiesen. Hierzu wurde der LightCycler FastStart DNA Masterplus SYBR Green I Kit eingesetzt, wobei die PCRReaktion in Glaskapillaren mit einem endgültigen Volumen von $20 \mu$ d durchgeführt wurde. Nach Herstellerempfehlung wurde der PCR-Mastermix angesetzt und die PCR-Ansätze entsprechend dem folgenden Schema pipettiert.

$4 \mu \mathrm{l} \quad$ PCR-Reaktionsgemisch

0,25 $\mu \mathrm{l} \quad$ Vorwärtsprimer (Toxo9: $12 \mu \mathrm{M}$, Toxo4, Sag1, Bag1 und Actin je $50 \mu \mathrm{M}$ )

0,25 $\mu \mathrm{l} \quad$ Rückwärtsprimer (Toxo11: $12 \mu \mathrm{M}$, Toxo5, Sag1, Bag1 und Actin je $50 \mu \mathrm{M}$ ) $5,5 \mu \mathrm{l} \quad \mathrm{H}_{2} \mathrm{O}$

$10 \mu \mathrm{l} \quad$ DNA Template

Die Kapillaren wurden verschlossen und bei 3000 x g für 30 Sekunden zentrifugiert, in den LightCycler übertragen und die unten aufgeführten PCR-Programme gestartet. Jeder PCR-Lauf umfasste neben den experimentellen Proben eine Negativkontrolle $\left(\mathrm{H}_{2} \mathrm{O}\right)$, um eine Kontamination der PCR-Reaktion auszuschließen, und eine Positivkontrolle (40 fg Toxoplasma-DNA). 
Tabelle 1: Real-time PCR-Programme

\begin{tabular}{llll}
\hline Zyklen & Stufe & Temperatur & Zeit \\
\hline $1 \mathrm{x}$ & Denaturierung & $95^{\circ} \mathrm{C}$ & 10 Minuten \\
$45 \mathrm{x}$ & Denaturierung & $95^{\circ} \mathrm{C}$ & 10 Sekunden \\
& Anealing für: & & \\
& $529-$-bp-Gen & $62^{\circ} \mathrm{C}$ & 10 Sekunden \\
& Sag1-Gen & $60^{\circ} \mathrm{C}$ & 10 Sekunden \\
& Actin-Gen & $62^{\circ} \mathrm{C}$ & 5 Sekunden \\
& Bag1-Gen & $60^{\circ} \mathrm{C}$ & 10 Sekunden \\
& Elongation für: & & \\
& $529-b p-G e n$ & $72^{\circ} \mathrm{C}$ & 10 Sekunden \\
& Sag1-Gen & $72^{\circ} \mathrm{C}$ & 20 Sekunden \\
& Actin-Gen & $72^{\circ} \mathrm{C}$ & 20 Sekunden \\
& Bag1-Gen & $72^{\circ} \mathrm{C}$ & 20 Sekunden \\
& Schmelzkurve & $95^{\circ} \mathrm{C}$ & 20 Sekunden \\
& & $66^{\circ} \mathrm{C}$ & 20 Sekunden \\
& & $95^{\circ} \mathrm{C}$ & 0 Sekunden \\
& & $40^{\circ} \mathrm{C}$ & 10 Sekunden \\
& & & \\
& Kühlung & &
\end{tabular}

\subsubsection{Nested PCR zum Nachweis von T. gondii genomischer DNA}

\subsubsection{Prinzip}

Nested PCR ist eine Methode, bei der zwei konventionelle PCR-Reaktionen nacheinender durchgeführt werden, um die Sensitivität der PCR weiter zu erhöhen, wobei man das PCR-Produkt einer ersten PCR als Template für die zweite PCR verwendet. Für die zweite Reaktion werden neue Primerpaare verwendet, die zwischen den Primern der ersten PCR liegen, dadurch werden nur die spezifischen DNAAbschnitte der ersten Reaktion amplifiziert. 


\subsubsection{Durchführung der nested PCR}

Die zwei PCR-Reaktionen der nested PCR wurden auf Basis des B1-Gens von T. gondii durchgeführt. Primerpaar Tg1/Tg2, das 468 bp des T. gondii-B1-Gens amplifiziert, wurden für die direkte PCR eingesetzt. Anschließend wurden das Primerpaar nested Tg1/nested Tg2, das 375 bp von dem ersten Produkt amplifiziert, verwendet.

Als Proben für die nested PCR kamen die für die Erstellung der Standardkurve für die real-time PCR verwendeten DNA-Proben (T.gondii in Mausgewebe) zum Einsatz. Nach dem Auftauen der PCR-Lösungen und DNA-Template auf Eis wurden sie gut gemischt, kurz zentrifugiert und dann in 0,5 ml-Reaktionsgefäße mit einem endgültigen Volumen von $25 \mu \mathrm{l}$ nach dem unten aufgeführten Pipettierschema angesetzt, in das PCR-Gerät überführt und das Programmm gestartet. Danach wurde die zweite PCR-Reaktion angesetzt, wobei als Template die Proben der ersten PCR-Reaktion verwendet wurden. Anschließend wurden die PCR-Produkte mittels Agarosegelelektrophorese analysiert.

Die Reaktionsansätze und die PCR-Bedingungen waren wie folgt:

Tabelle 2: Nested PCR-Pipettierschema

\begin{tabular}{lll}
\hline Komponenten & Volumen pro Ansatz & Endkonzentration \\
\hline 10 x PCR-Puffer & $2,5 \mu \mathrm{l}$ & $1 \times$ PCR-Puffer \\
dNTPs $(10 \mathrm{mM})$ & $1 \mu \mathrm{l}$ & $0,4 \mathrm{mM}$ \\
Vorwärtsprimer $(50 \mu \mathrm{M})$ & $0,5 \mu \mathrm{l}$ & $1 \mu \mathrm{M}$ \\
Rückwärtsprimer $(50 \mu \mathrm{M})$ & $0,5 \mu \mathrm{l}$ & $1 \mu \mathrm{M}$ \\
Taq-Polymerase $(5 \mathrm{U} / \mu \mathrm{l})$ & $0,3 \mu \mathrm{l}$ & $1,5 \mathrm{U}$ \\
$\mathrm{H}_{2} \mathrm{O}$-Bidest & $17,7 \mu \mathrm{l}$ & \\
DNA-Template & $2,5 \mu \mathrm{l}$ & \\
\hline
\end{tabular}


Tabelle 3: Nested PCR-Programm

\begin{tabular}{llll}
\hline Stufe & Zyklen & Temperatur & Zeit \\
\hline Denaturierung & $1 \mathrm{x}$ & $94^{\circ} \mathrm{C}$ & $2 \mathrm{~min}$ \\
& & & \\
Denaturierung & $35 \times$ für die erste & $94^{\circ} \mathrm{C}$ & 1 min \\
Amplifikation & $\begin{array}{l}\text { PCR-Reaktion } \\
25 \times \text { für die zweite } \\
\text { PCR-Reaktion }\end{array}$ & $55^{\circ} \mathrm{C}$ & 40 sek \\
Elongation & $72^{\circ} \mathrm{C}$ & 1 min \\
& & & \\
Primer Extension & $1 \mathrm{x}$ & $72^{\circ} \mathrm{C}$ & \\
Kühlung & $1 \mathrm{x}$ & $4^{\circ} \mathrm{C}$ & \\
\hline
\end{tabular}

\subsubsection{Agarose-Gelelektrophorese}

Um die Größe der PCR-Produkte durch Gelelektrophorese zu überprüfen, wurde 1\% (w/v) Agarose in $80 \mathrm{ml}$ 1x TAE-Puffer angesetzt und durch Aufkochen vollständig gelöst. Nach einer kurzen Abkühlung wurden $10 \mu \mathrm{l}$ Ethidiumbromid (Stammlösung $10 \mathrm{mg} / \mathrm{ml}$ ) dazugegeben und in die mit einem Probenkamm vorbereitete Gelkammer gegossen. Nach dem Aushärten der Agarose wurden $10 \mu$ I DNA mit $2 \mu$ 6x DNALoading-Puffer versetzt und in die Taschen des Gels aufgetragen. Ein 1 kb DNAMolekulargewichtsmarker wurde in eine Geltasche aufgetragen, um die Größe der DNA-Fragmente bestimmen zu können. Die Elektrophorese wurde in 1-fach TAEPuffer bei 120 V für 30 Minuten durchgeführt. Die Gele wurden mit einer BioDocllTM_ Anlage bei ultraviolettem (UV) Licht ausgewertet und zur Dokumentation digitalisiert bzw. Gelbilder mit einem Videoprinter ausgedruckt.

\section{TAE-Puffer}

$40 \mathrm{mM}$ Tris

$1 \%$ Essigsäure

1 mM EDTA (pH 8,0) 


\subsubsection{0 Überprüfen der Spezifität der Toxoplasma-real-time PCR mit DNA anderer Coccidia-Parasiten}

Zur Evaluierung der Spezifität der real time PCR wurden zunächst die genomischen DNA-Präparationen von verschiedenen Coccidia-Parasiten und die in dieser Arbeit verwendete T. gondii-DNA mit den Primern Toxo9/Toxo11, die an des 529-bprepetitive DNA-Fragment binden, amplifiziert (PCR-Durchführung und Programm, Kapitel 2.8.2). Danach wurden die gleichen DNA-Proben aus T. gondii und CoccidiaParasiten mit den Primern Coc1/Coc2 (je $5 \mu \mathrm{M}$ ), die das universell bei Coccidien vorkommende Gen der kleinen Untereinheit der ribosomalen RNA amplifizieren ( $\mathrm{Ho}$ et al. 1996) mittels qPCR untersucht. Das Pipettierschema und die Durchführung der Coccidia-PCR wurden, wie im Kapitel 2.8.2 beschrieben, durchgeführt. Das PCRProgramm auf Basis des universellen Gens der kleinen Untereinheit der ribosomalen RNA setzte sich wie folgt zusammen:

Tabelle 4: PCR-Programm für Coccidia-Parasiten

\begin{tabular}{llll}
\hline Zyklen & Stufe & Temperatur & Zeit \\
\hline $1 \mathrm{x}$ & Denaturierung & $94^{\circ} \mathrm{C}$ & $5 \mathrm{~min}$ \\
& & & \\
& & & \\
& & & \\
& Denaturierung & $94^{\circ} \mathrm{C}$ & 10 sek \\
& Amplifikation & $56^{\circ} \mathrm{C}$ (mit $0,5^{\circ} \mathrm{C}$ & 10 sek \\
& & weniger für jeden & \\
& & Zyklus nach dem & \\
& & Ersten bis $51^{\circ} \mathrm{C}$ und \\
& & dann weiter mit $51^{\circ} \mathrm{C}$ \\
& & für den Rest) & \\
& & $72^{\circ} \mathrm{C}$ & 15 sek \\
& & & \\
& Elongation & $95^{\circ} \mathrm{C}$ & 20 sek \\
& & $66^{\circ} \mathrm{C}$ & 20 sek \\
& Schmelzkurve & $95^{\circ} \mathrm{C}$ & 0 sek \\
& & $40^{\circ} \mathrm{C}$ & 10 sek \\
& & &
\end{tabular}




\subsubsection{Nachweis von Toxoplasma-mRNA mittels reverser Tran- skriptase-real-time PCR (RT-real-time PCR)}

Zusätzlich zu dem Nachweis von Toxoplasma-DNA in Gewebe der experimentell infizierten Hühner und Schweine wurde ermittelt, ob diese DNA von lebenden Parasiten stammt. Dafür wurde das Vorhandsein von T. gondii-mRNA in den positiven Gewebeproben mittels reverser Transkriptase-real-time PCR (RT-real-time PCR) untersucht. Um Toxoplasma-mRNA nachzuweisen, wurde zunächst die Sensitivität der RT-real-time PCR bestimmt, dabei wurde die Stadiumspezifität von T. gondii (Tachzoiten oder Bradyzoiten) berücksichtigt. Für die Untersuchung der Sensitivität der RT-real-time PCR wurde einerseits eine Verdünnungsreihe von bekannten Tachyzoiten-Mengen $\left(10^{6}, 10^{5}, 10^{4}, 10^{3}, 10^{2}\right.$, 10), wie im Kapitel 2.2.2 beschrieben, hergestellt, RNA mittels des GenElute ${ }^{T M}$ Mammalian Total RNA Miniprep Kits isoliert (Kapitel 2.2.6) und cDNA mittels des Sensiscript Reverse Transkription Kits synthetisiert (Kapitel 2.2.7). Außerdem wurden die gleichen vorgenannten TachyzoitenMengen mit jeweils 25 mg Mausmuskulatur oder Gehirn inokuliert, RNA isoliert und in cDNA umgeschrieben. Anschließend wurde cDNA des Sag1-Gens, das tachyzoitenspezifisch ist (Burg et al. 1988), in der real-time PCR amplifiziert. Dazu wurde hier Actin-cDNA von T. gondii als konstitutiv exprimiertes Gen (als Kontrolle) amplifiziert. Die Primerpaare sag1 for/sag1 rev (Fux et al. 2007) und TgActin for /TgActin rev wurden für die RT-real-time PCR verwendet.

Anderseits wurde die Sensitivität der RT-real-time PCR für den Bradyzoitennachweis mit Verdünnungsreihe von Gewebezysten aus Gehirnen infizierter Mäuse bestimmt. Die infizierte Maus wurde mit Hilfe von $\mathrm{CO}_{2}$ getötet, präpariert, das Gehirn in PBS aufgenommen und gewaschen. Anschließend wurde das Gehirn in $1 \mathrm{ml}$ PBS überführt und durch kräftiges Vortexen mit Glaskugeln homogenisiert. Die Zystenanzahl in jeweils $30 \mu \mathrm{l}$ Gehirnsuspension wurde unter dem Lichtmikroskop drei bis vier Male ausgezählt und davon der Mittelwert berechnet. Anschließend wurde eine Verdünnungsreihe von unterschiedlicher Zystenanzahl (0.0001 Zysten, 0.001 Zysten, 0.01 Zysten, 0.1 Zysten, 1 Zysten und 10 Zysten) in PBS-Puffer hergestellt, RNA isoliert und in cDNA umgeschrieben. Danach wurde die cDNA des Bag1-Gens, das bradyzoitenspezifisch ist (Bohne et al. 1995) in der real-time PCR amplifiziert. Als Primer zum Nachweis der Bag1-mRNA wurden die Primer bag1 for/ bag1 rev aus 
den Literatur ausgewählt (Fux et al. 2007). Außerdem wurden als Kontrolle die cDNAs von Toxoplasma-Actin und Sag1 amplifiziert.

Um zu ermitteln, ob T. gondii-mRNA in Gewebeproben von experimentell infizierten Hühnern und Schweinen nachweisbar ist, wurde von jeweils $25 \mathrm{mg}$ verschiedener Gewebe aus Schweinen und Hühnern RNA isoliert und in CDNA mittels des Sensiscript Reverse Transkription Kits umgeschrieben (Kapitel 2.2.7) und in der real-time PCR amplifiziert. Als Positivkontrolle wurde die bereits in PBS hergestellte Gehirnsuspension mit der vorgenannten Verdünnung von 10 Zysten mitgeführt. Die realtime PCR zum Nachweis von Toxoplasma-mRNA im Gewebe der experimentell infizierten Schweine und Hühner erfolgte auf Basis des Bag1-mRNA mit den Primern bag1 for/bag1 rev. 


\section{Ergebnisse}

\subsection{Nachweis von Toxoplasma-DNA in Mausgewebe und Bestimmung von Parasitenmengen mittels real-time PCR}

Um Toxoplasma-DNA in Gewebeproben nachzuweisen und anhand einer Standardkurve Parasitenmengen quantifizieren zu können, wurde eine real-time PCR auf Basis des 529-bp-Fragmentes von T. gondii etabliert. Dafür wurden zwei Primerpaare (Toxo9 for/Tox011 rev und Toxo4 for/Toxo5 rev) aus der Literatur ausgewählt (Reischl et al. 2003; Homan et al. 1999. siehe Kapitel 2.1.6) und in der real-time PCR getestet. Die Amplifikation erfolgte in 45 Zyklen, CP-Werte $>41$ wurden negativ bewertet.

\subsubsection{Nachweis von T. gondii-DNA mittels real-time PCR mit Primern Toxo9/Toxo11}

Zur Etablierung der real-time PCR und Erstellung einer Standardkurve wurde eine Verdünnungsreihe von verschiedenen Toxoplasma-Mengen $\left(10^{4}, 10^{3}, 10^{2}, 10,2.5\right)$ in Mausgewebe hergestellt. Dazu wurden jeweils $25 \mathrm{mg}$ Mausmuskulatur oder Mausgehirn mit den vorgenannten Toxoplasma-Mengen inokuliert, als Negativkontrolle wurde Gewebe ohne Parasiten parallel mitgeführt. Als Positivkontrolle wurde $40 \mathrm{fg}$ Toxoplasma-DNA verwendet. Die real-time PCR mit Primerpaar Toxo9/Toxo11 zeigte, dass der Erreger in allen Proben nachgewiesen werden konnte, die mit 2,5 oder mehr Parasiten pro $25 \mathrm{mg}$ Gewebe inokuliert worden waren. Dabei entsprach eine Menge von 2,5 Parasiten pro $25 \mathrm{mg}$ Gewebe $0.1 \mathrm{~T}$. gondii pro PCR. Die CPWerte der real-time PCR zeigten eine gute Abhängigkeit von der Parasitenanzahl: je größer die T. gondii-DNA-Menge in der Probe war, desto früher stieg das Fluoreszensignal über den Grenzwert (Abbildung 2). Die Negativkontrollen von Mausgewebe ohne Parasiten zeigten einen CP-Wert von über 41 und wurden daher als negativ bewertet (Abbildung 2). Die Amplifikationen der Parasiten-DNA von inokulierter Mausmuskulatur und Mausgehirn zeigten vergleichbare Verläufe, die Amplifikation von DNA aus Muskulaturproben war geringfügig empfindlicher als die aus Gehirnproben (Abbildung 2). 
A.

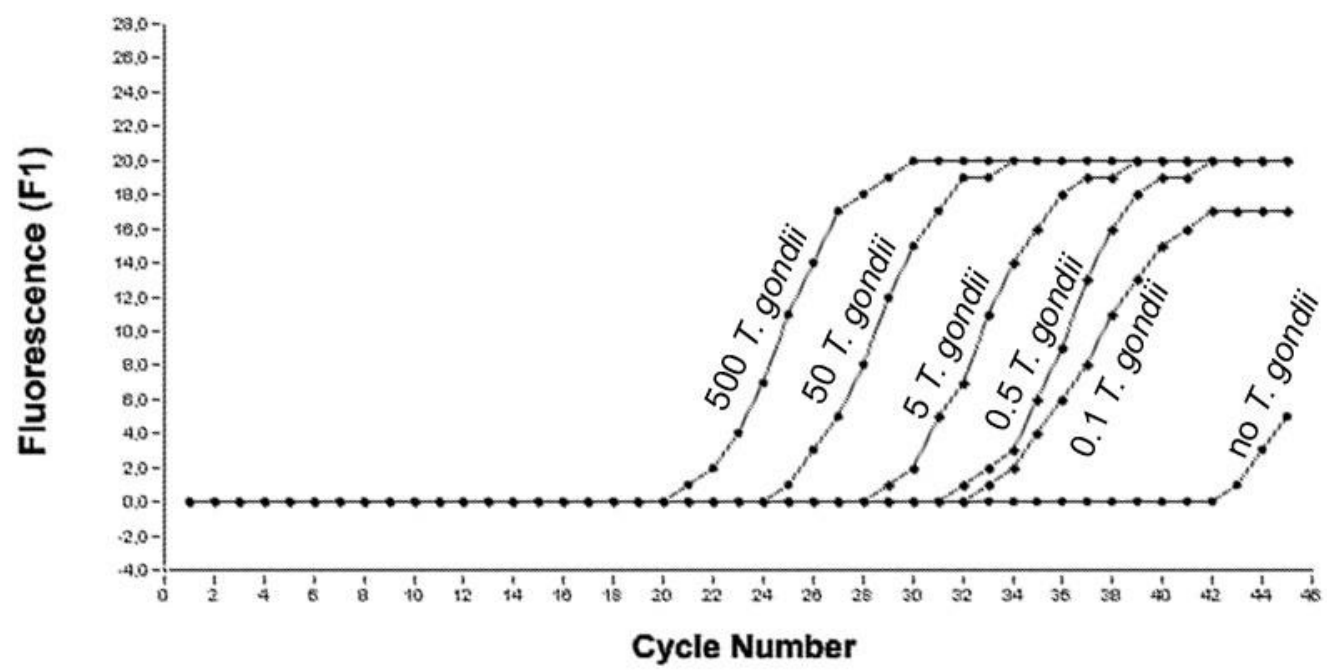

B.

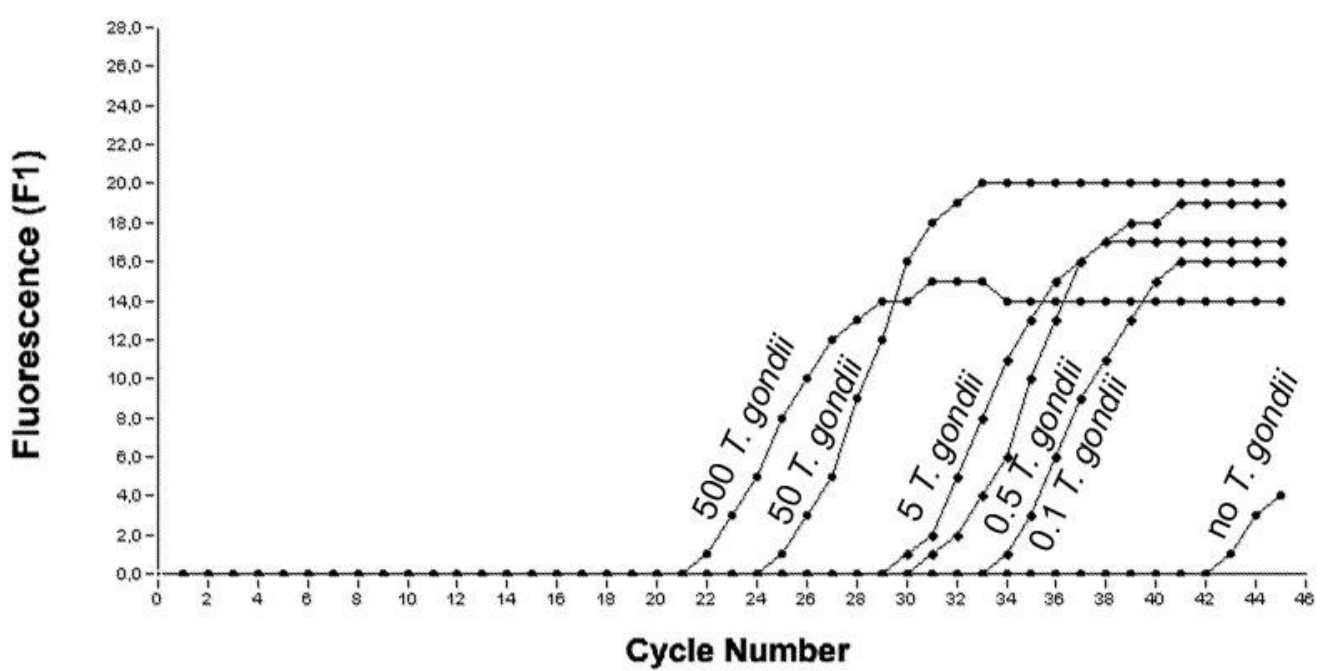

Abbildung 2: Real-time PCR von Toxoplasma-DNA nach Extraktion verschiedener ToxoplasmaMengen $\left(10^{4}, 10^{3}, 10^{2}, 10,2.5,0\right)$ mit $25 \mathrm{mg}$ Mausgewebe (A. Muskulatur und B. Gehirn) mittels Oligonukleotidprimer Toxo9 und Toxo11 unter Verwendung des Fluoreszenfarbstoffes SYBR Green. Die Graphen zeigen Amplifikationsverläufe von DNA-Proben unterschiedlicher Parasitenmengen, die Parasitenzahlen entsprechen den Mengen pro PCR, wobei pro PCR 5\% der ursprünglich extrahierten DNA eingesetzt wurde. Ein repräsentatives Experiment von mehreren PCR-Versuchen ist dargestellt.

Um die spezifischen PCR-Produkte von eventuell auftretenden unspezifischen Amplifikaten oder Primerdimeren zu unterscheiden, wurde auch eine Schmelzkurvenanalyse durchgeführt. Dabei weisen die spezifischen PCR-Produkte in der Regel 
einen höheren Schmelzpunkt auf als unspezifische Signale wie z.B. Primerdimere. Die Schmelzkurve der mit Parasiten versetzten Gewebeproben wurde mit der Positivkontrolle (40 fg Toxoplasma-DNA) verglichen. Die durchgeführten Schmelzkurven unserer real-time PCR zeigten die weitgehende Spezifität der amplifizierten DNA-Fragmente. Lediglich bei Proben ohne spezifisches Template oder sehr geringer Ausgangmenge von Toxoplasma-DNA wurden teilweise unspezifische Signale geringer Intensität nachgewiesen (nicht gezeigte Ergebnisse).

Die Spezifität der real-time-PCR-Podukte wurde außerdem mittels AgaroseGelelektrophorese (Kapitel 2.2.9.3) überprüft (Abbildung 3). Ein Fragment mit der erwarteten Größe von 162 bp wiesen alle Proben von Mausmuskulatur oder Mausgehirn auf, die mit 2,5 oder mehr Parasiten pro 25 mg Gewebe inokuliert worden waren sowie die Positivkontrolle (PK). In der Negativkontrolle (Gewebe ohne Parasiten) war dagegen keine Bande der erwarteten Größe zu erkennen.

A.

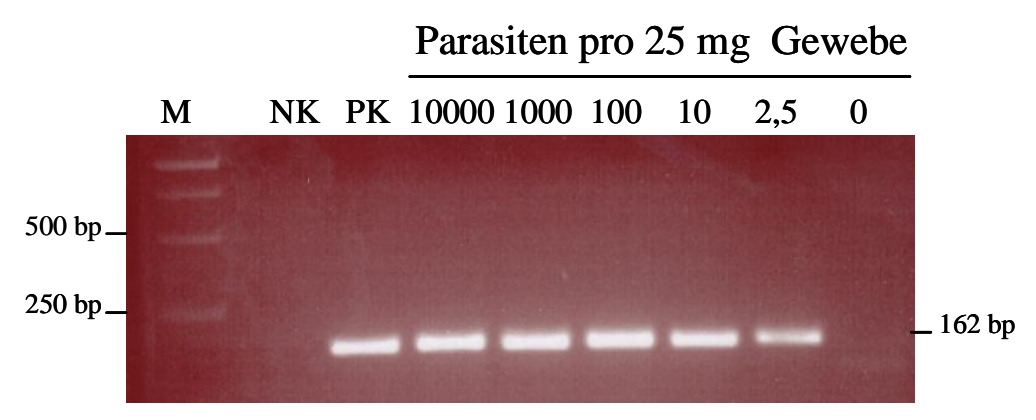

B.

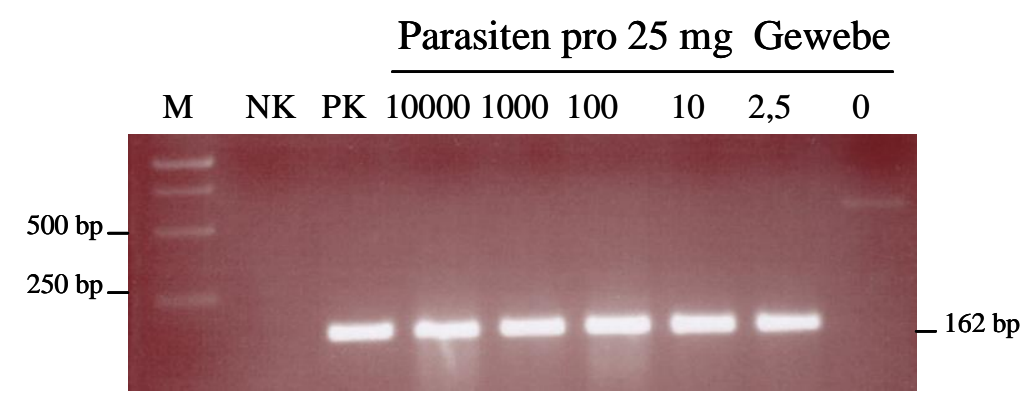

Abbildung 3: Agarose-Gelelektrophorese von PCR-Amplifikaten nach real-time PCR von Toxoplasma gondii-haltigen Gewebeproben mittels Primer Toxo9 und Tox011. Mausmuskulatur (A) oder Mausgehirn (B) wurde mit unterschiedlichen Mengen von Toxoplasma-Parasiten inokuliert und DNA extrahiert. DNA wurde durch real-time PCR amplifiziert, als Negativkontrolle (NK) wurde $\mathrm{H}_{2} \mathrm{O}$, als Positivkontrolle (PK) $40 \mathrm{fg}$ Parasiten-DNA mitgeführt. Die PCR-Produkte wurden durch Agarose-Gelelektrophorese aufgetrennt und mittels Ethidiumbromid und UV-Licht sichtbar gemacht. 
Eine Quantifizierung von PCR-Produkten ist mit Hilfe einer Standardkurve möglich, die mit bekannten DNA-Mengen erstellt wird. In dieser Arbeit wurde eine Standardkurve aus den in Abbildung 2 exemplarisch gezeigten Ergebnissen erstellt, um in folgenden Untersuchungen unbekannte T. gondii-DNA-Mengen anhand der real-time PCR zu quantifizieren. So wurden aus den CP-Werten mehrerer Versuche mit Toxoplasma-inokulierter Muskulatur und Gehirn die Mittelwerte berechnet und gegen die Ausgangsmenge der Toxoplasmen aufgetragen (Abbildung 4). Über die Steigung der Geraden konnte dabei die Effizienz der Amplifikation bestimmt werden, bei Verdoppelung des PCR-Produktes in jedem PCR-Zyklus beträgt die Effizienz der Amplifikation 2 und ist damit optimal. Die Steigung der Standardkurve nach Amplifikation verschiedener Toxoplasma-Mengen betrug -3.412, die Effizienz der real-time PCR mit Primer Toxo9 und Toxo11 wurde mit 1.96 berechnet (Abbildung 4). Sie kommt dem Maximalwert von 2.0 nahe und deutet auf eine sehr gute Effizienz der Amplifikation des Toxoplasma-529-bp-Fragmentes mittels Primer Toxo9 und Toxo11 hin. Der Korrelationskoeffizient $\left(r^{2}\right)$ betrug 0.988 und bewies damit eine sehr gute Korrelation der CP-Werte und der Parasitenanzahl.

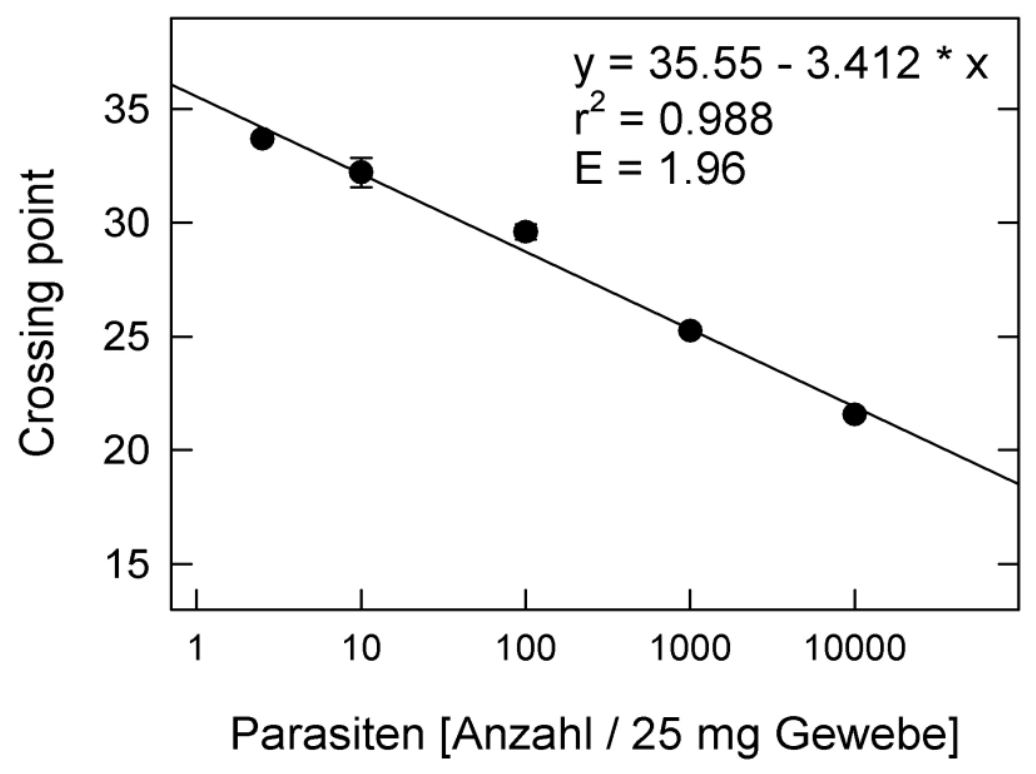

Abbildung 4: Standardkurve einer Verdünnungsreihe von verschiedenen Toxoplasma gondii-Mengen pro $25 \mathrm{mg}$ Mausgewebe nach Amplifikation der Parasiten-DNA mittels real-time PCR. Mausmuskulatur oder Mausgehirn wurden mit definierten Parasitenmengen versetzt, DNA extrahiert und das 529-bpFragment mittels real-time PCR und Primerpaar Toxo9/Toxo11 amplifiziert. Gezeigt sind die mittleren CPWerte +/- S.E.M (Standardfehler). $(n=2)$. Mit den Daten wurde eine Regressionsanalyse durchgeführt, aus der Steigung der Regressionsgerade wurde die Effizienz E der DNA-Amplifikation berechnet. Der Korrelationskoeffizient $r^{2}$ ist angegeben. 
Die Ergebnisse der 529-bp-Fragment-basierten real-time PCR mit den Primern Toxo9/Toxo11 erlaubte einen deutlichen Nachweis von T. gondii-DNA in den mit verschiedenen Parasitenmengen versetzten Mausgeweben ab einer Menge von 0,1 Parasit pro PCR, die damit eine gute Sensitivität zeigte.

\subsubsection{Nachweis von T. gondii-DNA mittels real-time PCR mit Pri- mern Toxo4 und Toxo5}

Auf Grundlage des 529-bp-repetitiven Gens von T. gondii wurden auch die Oligonukleotidprimer Toxo4 und Toxo5 zur Durchführung einer real-time PCR und Erstellung der zugehörigen Standardkurve überprüft. Dafür wurde eine Verdünnungsreihe von unterschiedlichen Toxoplasma-Mengen $\left(10^{4}, 10^{3}, 10^{2}, 10\right)$ hergestellt. Mit den vorgenannten Parasitenmengen wurden jeweils $25 \mathrm{mg}$ Mausmuskulatur oder Mausgehirn inokuliert. Als Positivkontrolle wurde $40 \mathrm{fg}$ Toxoplasma-DNA und Gewebe ohne Parasiten als Negativkontrolle parallel mitgeführt. Das Primerpaar Toxo4 und Toxo5 wurde in der real-time PCR mit einer Annealingtemperatur von $64^{\circ} \mathrm{C}$ und auch $65^{\circ} \mathrm{C}$ überprüft. Die Analyse erfolgte unter den unter Punkt 2.2.8.2 aufgeführten Reaktionsbedingungen und in Mehrfachansätzen. Die real-time PCR mit Primerpaar Toxo4 und Toxo5 zeigte, dass die T. gondii-DNA in allen Proben amplifiziert werden konnte, die mit 10 oder mehr Parasiten pro 25 mg Gewebe versetzt worden waren. Dabei entsprach eine Menge von 10 Parasiten pro $25 \mathrm{mg}$ Gewebe 0.5 T. gondii pro PCR. Außerdem bewiesen die CP-Werte der real-time PCR mit den Primern Toxo4 und Toxo5 eine gute Korrelation mit den Parasitenmengen, wobei bei höherer Parasitenanzahl ein früherer Anstieg des Fluoreszenzsignals über den Grenzwert erhalten wurde (Abbildung 5). Die mitgeführten Negativkontrollen von Mausgewebe ohne Parasiten zeigten hier kein Amplifikationssignal und wurden daher als negativ bewertet (Abbildung 5). Beim Vergleich der Amplifikationsverläufe von inokulierter Mausmuskulatur und Mausgehirn ist zu erkennen, dass die Amplifikation von DNA aus Gehirnproben mittels real-time PCR mit den Primern Tox04/Tox05 geringfügig sensitiver war als die aus den Muskelproben (Abbildung 5). Die zugehörigen Schmelzkurven zeigten den gleichen Schmelzkurvenpeak der Positivkontrolle. Unspezifische Signale wurden nur bei Proben nachgewiesen, die kein spezifisches Template enthielten oder sehr geringe Ausgangmengen von Toxoplasma-DNA enthielten (nicht gezeigte Ergebnisse). 
A.

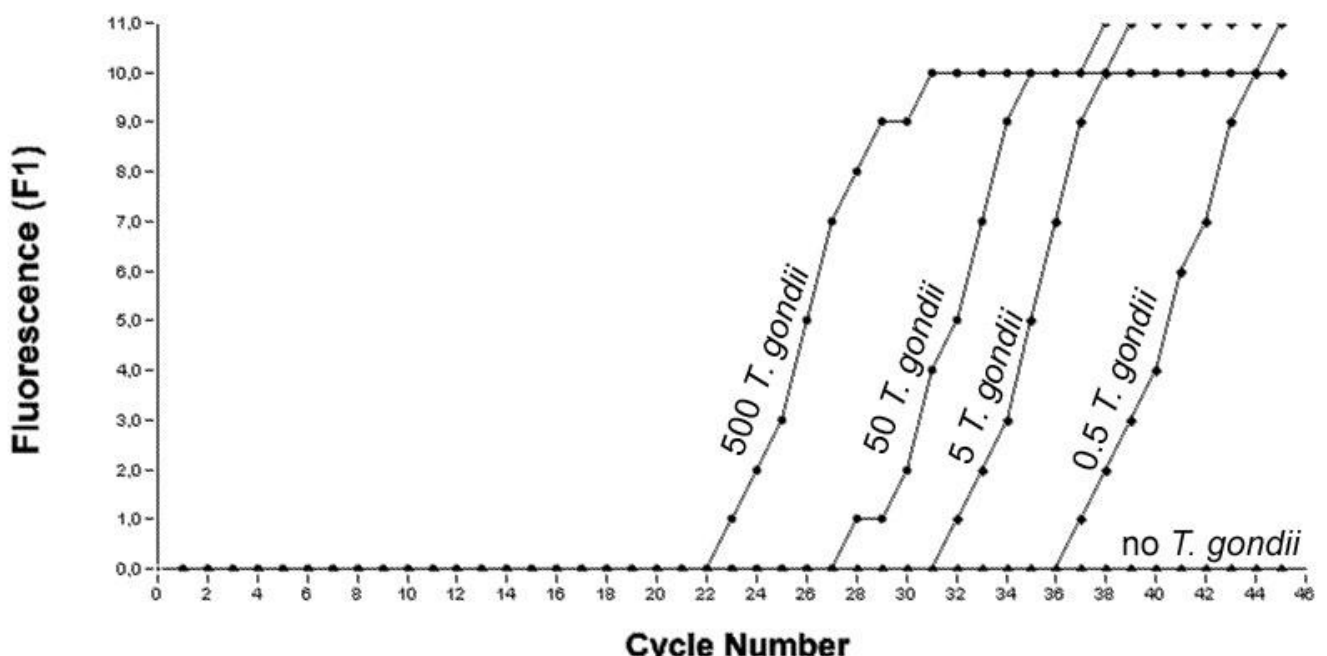

B.

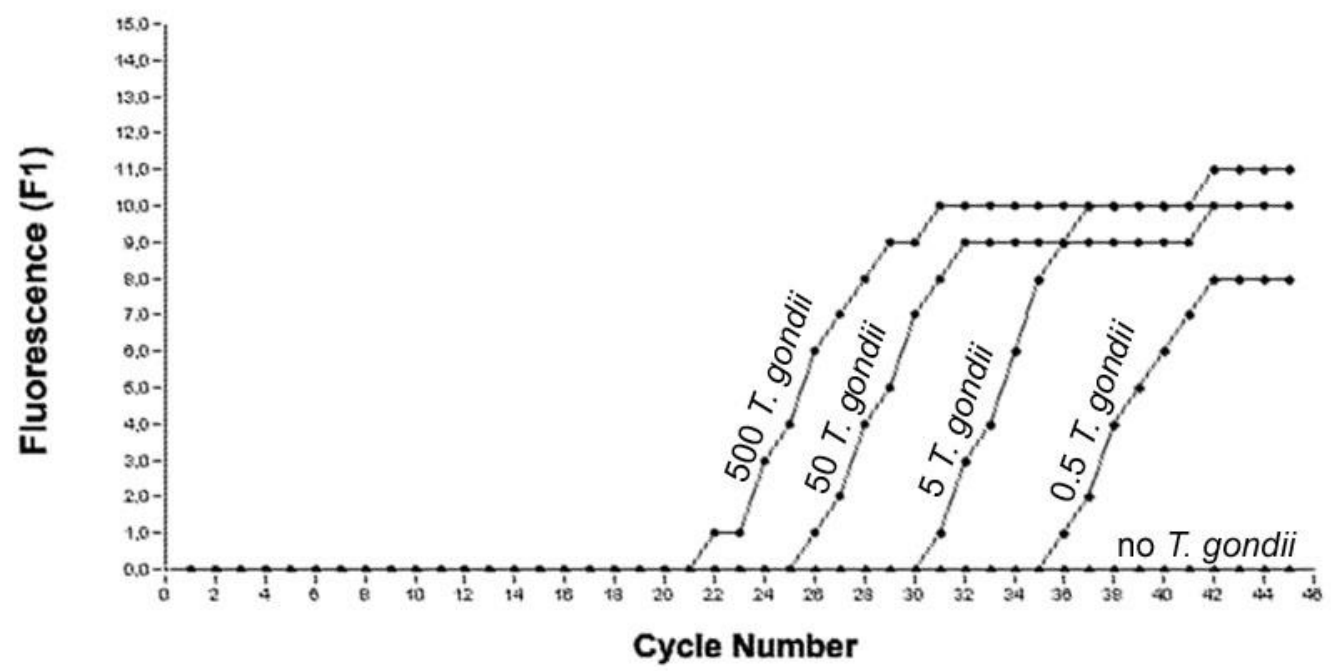

Abbildung 5: Real-time PCR von Toxoplasma-DNA nach Extraktion verschiedener ToxoplasmaMengen $\left(10^{4}, 10^{3}, 10^{2}, 10,0\right)$ mit $25 \mathrm{mg}$ Mausgewebe (A. Muskulatur und B. Gehirn) mittels Oligonukleotidprimer Toxo4 und Toxo5 unter Verwendung des Fluoreszenfarbstoffes SYBR Green. Die Graphen zeigen Amplifikationsverläufe von DNA-Proben unterschiedlicher Parasitenmengen, die Parasitenzahlen entsprechen den Mengen pro PCR, wobei pro PCR 5\% der ursprünglich extrahierten DNA eingesetzt wurde. Ein repräsentatives Experiment von mehreren PCR-Versuchen ist dargestellt. 
Die Spezifität der gebildeten PCR-Podukte mit dem Primerpaar Toxo4/Toxo5 wurde auch mittels Agarose-Gelelektrophorese (Kapitel 2.2.9.3) überprüft (Abbildung 6). Die Ergebnisse zeigten das erwartete Fragment mit einer Größe von 529 bp in allen Proben von Mausmuskulatur oder Mausgehirn, die mit 10 oder mehr Parasiten pro 25 mg Gewebe inokuliert worden waren sowie in der Positivkontrolle (PK). Dagegen war in der Negativkontrolle (Gewebe ohne Parasiten) keine spezifische Bande zu erkennen.

A.

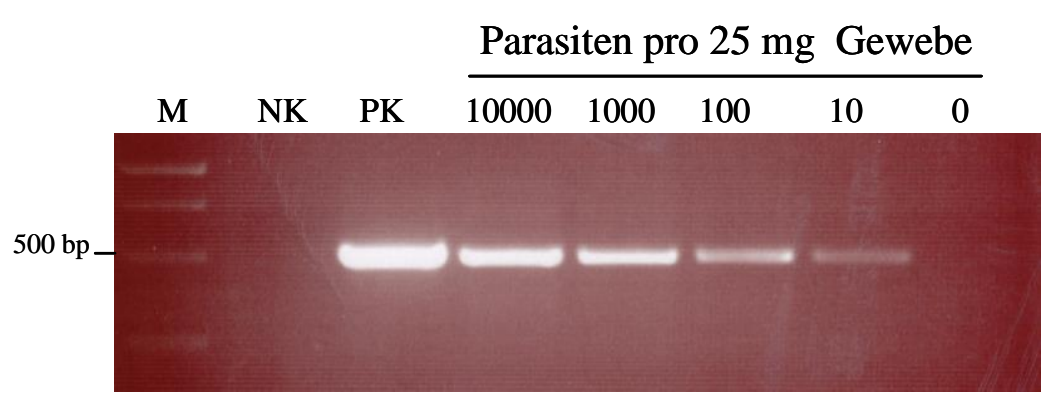

B.

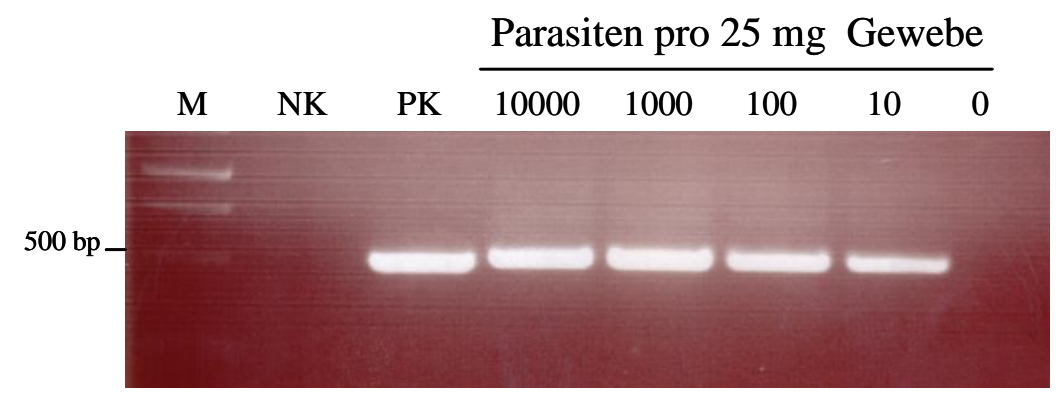

Abbildung 6: Agarose-Gelelektrophorese von PCR-Amplifikaten nach real-time PCR von Toxoplasma gondii-haltigen Gewebeproben mittels Primer Toxo4 und Toxo5. Mausmuskulatur (A) oder Mausgehirn (B) wurde mit unterschiedlichen Mengen von Toxoplasma-Parasiten inokuliert und DNA extrahiert. DNA wurde durch real-time PCR amplifiziert, als Negativkontrolle $(\mathrm{NK})$ wurde $\mathrm{H}_{2} \mathrm{O}$, als Positivkontrolle (PK) $40 \mathrm{fg}$ Parasiten-DNA mitgeführt. Die PCR-Produkte wurden durch Agarose-Gelelektrophorese aufgetrennt und mittels Ethidiumbromid und UV-Licht sichtbar gemacht. 
Um die Standardkurven der real-time PCR mit den Primern Toxo4/Toxo5 zu erstellen, wurden aus den CP-Werten mehrerer Versuche mit Toxoplasma-versetzter Mausmuskulatur oder Mausgehirn unabhängig von den Annealingtemperaturen die Mittelwerte berechnet und gegen den Logarithmus der Ausgangsmenge der Toxoplasmen dargestellt (Abbildung 7: A. Mausmuskulatur und B. Mausgehirn). Die Steigung der Standardkurven der mit Toxoplasma inokulierten Mausmuskulatur oder Mausgehirn nach Amplifikation verschiedener Toxoplasma-Mengen betrug -4.754, bzw. -4,312. Damit wurde die Effizienz der real-time PCR mit den Primern Toxo4 und Toxo5 mit 1.62 bzw. 1.71 berechnet (Abbildung 7). Der Korrelationskoeffizient $\left(\mathrm{r}^{2}\right)$ betrug 0.994 für den Muskulaturversuch und 0.996 für den Gehirnversuch und zeigte damit eine sehr gute Korrelation der CP-Werte der real-time PCR mit den Primern Toxo4/Toxo5 und der Parasitenanzahl. 
A.

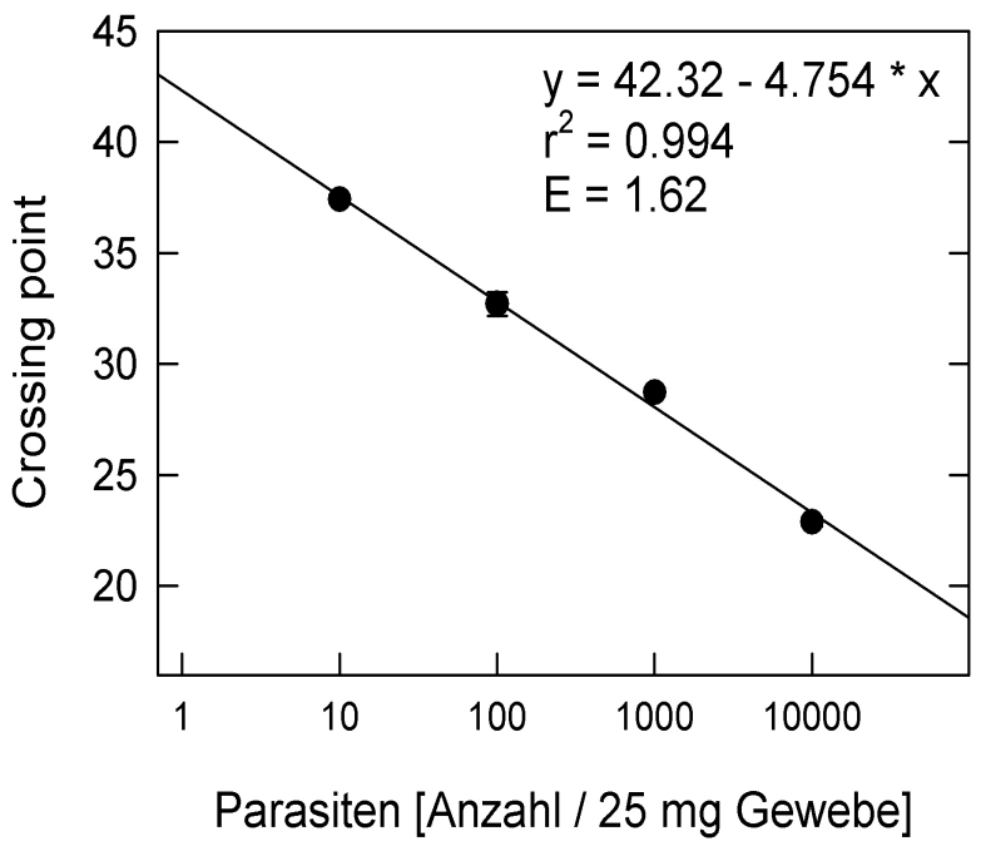

B.

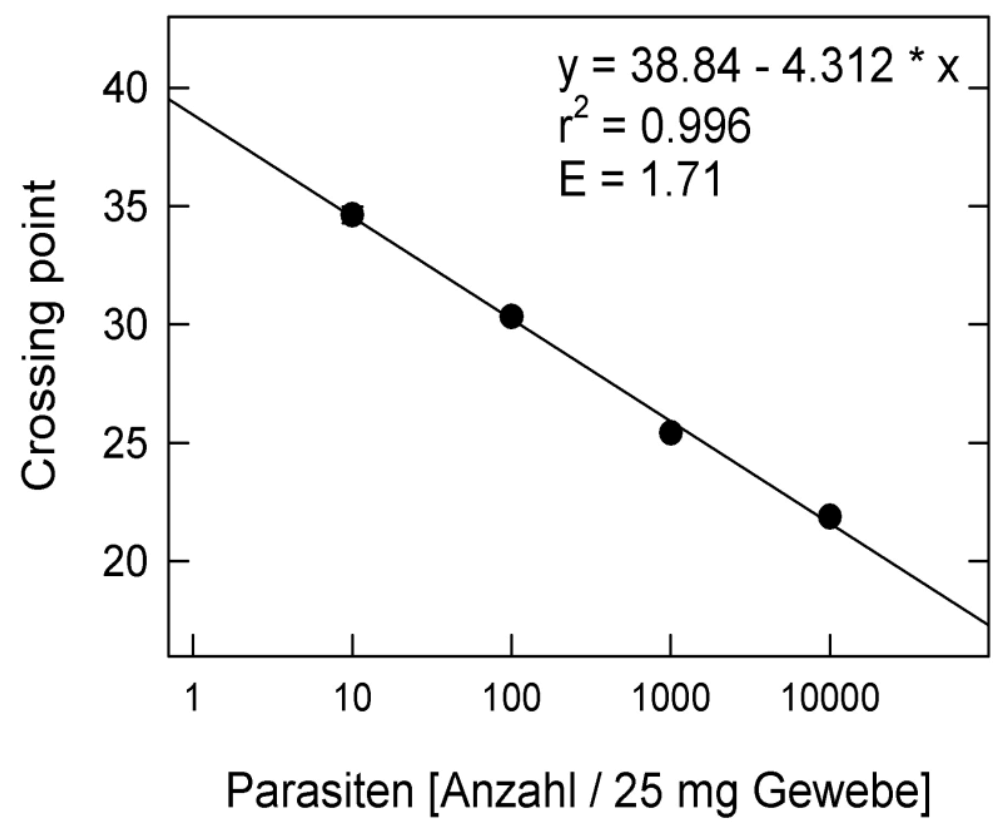

Abbildung 7: Standardkurve einer Verdünnungsreihe von verschiedenen Toxoplasma gondii-Mengen pro $25 \mathrm{mg}$ Mausgewebe (A. Muskulatur und B. Gehirn) nach Amplifikation der Parasiten-DNA mittels realtime PCR. Mausmuskulatur oder Mausgehirn wurden mit definierten Parasitenmengen versetzt, DNA extrahiert und das 529-bp-Fragment mittels real-time PCR und Primerpaar Toxo4/Toxo5 amplifiziert. Gezeigt sind die mittleren CP-Werte +/- S.E.M. ( $n=3$ jeweils für Muskulatur und Gehirn). Mit den Daten aus Muskulatur oder Gehirnversuch wurde eine Regressionsanalyse durchgeführt, aus der Steigung der Regressionsgerade wurde die Effizienz E der DNA-Amplifikation berechnet. Der Korrelationskoeffizient $\mathrm{r}^{2}$ ist angegeben. 
Die Standardkurve ermöglicht nicht nur die Quantifizierung unbekannter Parasitenmengen anhand einer Standardgeradengleichung, sondern hilft auch bei einer Evaluation der Reaktionseffizienz und damit dem Amplifikationsverlauf. Ausgehend von den in Abbildungen 2 und 5 gezeigten Daten der real-time PCR mittels der Primerpaare Toxo9/Toxo11 und Toxo4/Toxo5 und den zugehörigen Standardkurven ist zu erkennen, dass die Amplifikation von T. gondii-DNA aus den mit verschiedenen Parasitenmengen versetzten Gewebeproben mittels real-time PCR mit den Primern Toxo9/Toxo11 deutlich empfindlicher war (Abbildung 2) als die mit den Primern Toxo4/Toxo5 (Abbildung 5). Dabei zeigte die real-time PCR mittels Primerpaar Toxo9/Toxo11 eine höhere Effizienz der Amplifikation des Toxoplasma-529-bpFragmentes (Abbildung 4) im Vergleich zu der mittels Primer Toxo4/Toxo5 (Abbildung 7). Deshalb wurden die Primer Toxo4 und Toxo5 von weiteren Versuchen ausgeschlossen.

\subsection{Weitere Untersuchungen zur Sensitivität des Toxo- plasma-Nachweises in Wirtsgewebe mittels PCR}

In weiteren Untersuchungen wurde der Toxoplasma-Nachweis in Wirtsgewebe mit einer anderen Methode (nested PCR) bestimmt und die Sensitivität dieser Methode mit der der real-time PCR verglichen. Außerdem wurde auch der Einfluss von Wirtsgewebe auf die Sensitivität der real-time PCR evaluiert.

\subsubsection{Nachweis von T. gondii-DNA im Mausgewebe mittels nested PCR}

Zur Etablierung der nested PCR und zur Ermittlung ihrer Sensitivität zum Nachweis von T. gondii in Gewebeproben wurde mit der unter Punkt 3.1.1 genannten Verdünnungsreihe von verschiedenen Toxoplasma-Mengen $\left(10^{4}, 10^{3}, 10^{2}, 10,2.5\right)$ jeweils $25 \mathrm{mg}$ Mausmuskulatur und Mausgehirn inokuliert. Die nested PCR erfolgte auf Basis des B1-Gens von T. gondii. Dafür wurden aus der Literatur das Primerpaar Tg1 for/Tg2 rev für die erste PCR und das Primerpaar Tg.nested1 for/Tg.nested2 rev für die zweite PCR ausgewählt (Jalal et al. 2004, siehe Kapitel 2.1.6). Als Negativkontrolle wurde Gewebe ohne Parasiten parallel mitgeführt. PCR-Pipettierschema 
und PCR-Programme für die erste und zweite PCR sind in Kapitel 2.2.9.2 aufgeführt. Die Überprüfung der Spezifität der erhaltenen PCR-Produkte erfolgte anschließend mittels Agarose-Gelelektrophorese.

Die Ergebnisse der nested PCR zeigten, dass der Erreger ab einer ToxoplasmaMenge von 10 Parasiten pro 25 mg Mausmuskulatur oder Mausgehirn nachgewiesen werden konnte, dabei wurde ein Fragment mit der erwarteten Größe von 375 bp erhalten (Abbildung 8). Dagegen war die Amplifikation der T. gondii-DNA mittels nested PCR in Proben, die mit 2,5 Parasiten pro 25 mg Gewebe versetzt wurden, nicht erfolgreich (Abbildung 8). Hier konnte wie auch in der Negativkontrolle (Gewebe ohne Parasiten) keine Bande der erwarteten Größe nachgewiesen werden. Das deutete darauf hin, dass die Sensitivität der nested PCR zur Detektion von T. gondiiDNA in Gewebe im Vergleich zur real-time PCR geringer war. 
A.

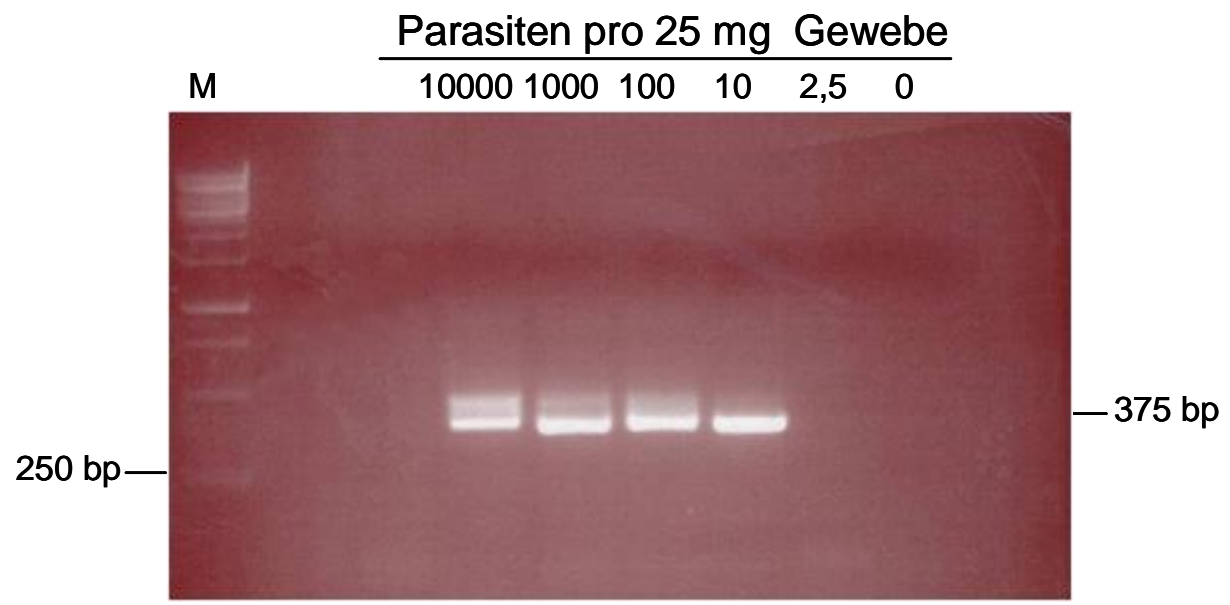

B.

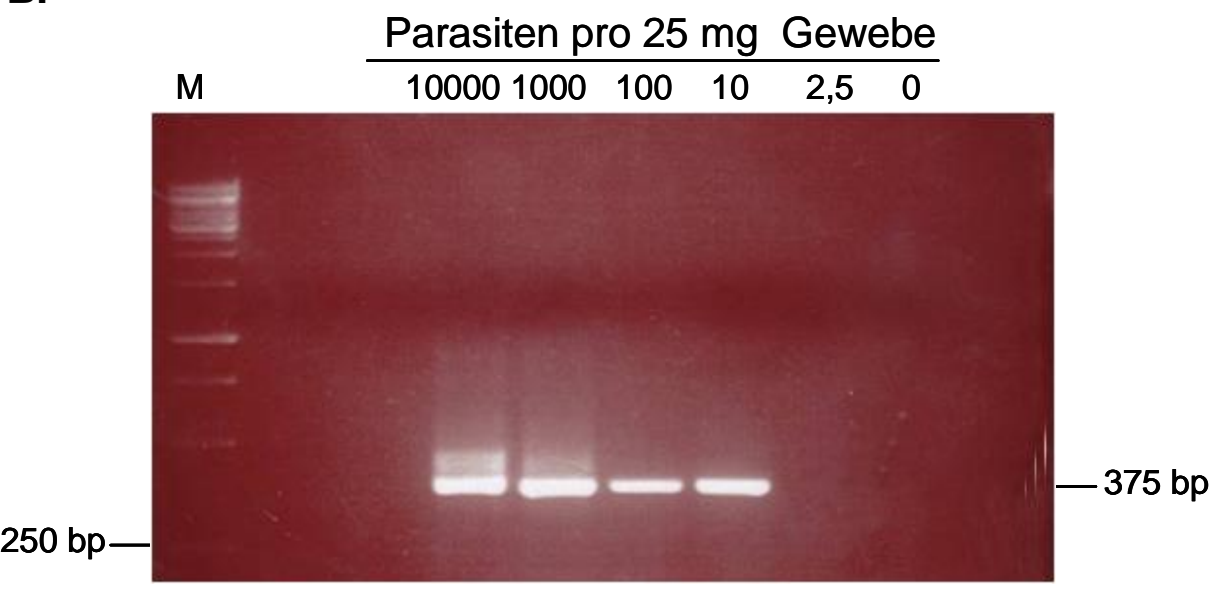

Abbildung 8: Agarose-Gelelektrophorese von PCR-Produkten nach nested PCR der Toxoplasma gondii-haltigen Gewebeproben. Mausmuskulatur (A) oder Mausgehirn (B) wurden mit verschiedenen Toxoplasma-Mengen inokuliert und DNA extrahiert. DNA wurde durch nested PCR amplifiziert, bei der zwei konventionelle PCR-Reaktionen nacheinender auf Basis des B1-Gens von $T$. gondii durchgeführt wurden. Als Negativkontrolle wurde Gewebe ohne Parasiten mitgeführt. M: 1kb DNA-Marker. Die nested PCR-Produkte wurden durch Agarose-Gelelektrophorese aufgetrennt und mittels Ethidiumbromid und UV-Licht sichtbar gemacht.

\subsubsection{Einfluss von Wirtsgewebe auf die T. gondii-529-bp-real-time PCR}

In weiteren Experimenten wurde der Einfluss von Wirtsgewebe auf den Nachweis von Toxoplasma gondii DNA mittels real-time PCR evaluiert. Hierfür wurden Toxo- 
plasma-Tachyzoiten aus der Zellkultur gewonnen (Kapitel 2.1.2.1) und Mengen von $10^{4}, 10^{3}, 10^{2}$ und 10 Parasiten in PBS-Puffer titriert.

Um zu ermitteln, wie stark die Wirtsgewebe die Sensitivität der PCR beeinflussen, wurde DNA aus den vorgenannten isolierten Toxoplasma-Proben einerseits ohne Gewebe und andererseits nach der Zugabe von je $25 \mathrm{mg}$ Mausmuskulatur oder Mausgehirn extrahiert und anschließend als Template in der real-time PCR mit den Primern Toxo9/Toxo11 eingesetzt. Als Positivkontrolle wurde 40 fg Toxoplasma-DNA und als Negativkontrolle Gewebe ohne Parasiten parallel mitgeführt. Nach mehreren PCR-Versuchen zeigten die Ergebnisse, dass die Amplifikation der T. gondii-DNA aus unterschiedlichen Parasitenmengen ohne Gewebe mittels real-time PCR deutlich empfindlicher war als die von Parasiten-inokulierter Mausmuskulatur oder Mausgehirn (Abbildung 9). So wurden signifikante Amplifikationssignale von Parasiten in Mausgewebe etwa drei Zyklen später als die von Parasiten ohne Gewebe erhalten (Abbildung 9). Das wies darauf hin, dass die Gewebe den Nachweis von T. gondiiDNA beeinträchtigten und die Sensitivität der T. gondii real-time PCR im Gewebe verringerten.

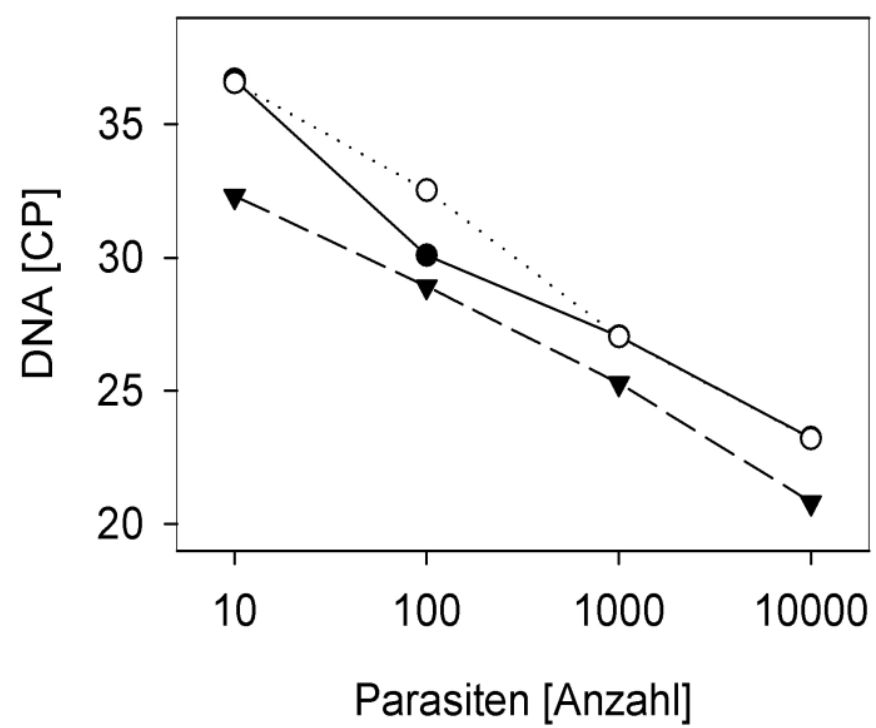

$\longrightarrow$ T. gondii / 25 mg Muskel

-.... T. gondii / 25 mg Gehirn

$-\nabla-\quad$ T. gondii ohne Gewebe

Abbildung 9: Real-time PCR von T. gondii-DNA aus unterschiedlichen Parasitenmengen $\left(10^{4}, 10^{3}, 10^{2}\right.$, 10) ohne und mit Mausgewebe zur Ermittlung des Einflusses der Wirtsgewebe auf die real-time PCR. Die DNA wurde aus den Toxoplasma-Mengen einerseits ohne Gewebe und andererseits mit jeweils $25 \mathrm{mg}$ Mausmuskulatur oder Mausgehirn extrahiert und in der real-time PCR mittels Primer Toxo9 und Toxo11 amplifiziert. Nach mehreren PCR-Versuchen wurden die Mittelwerte der CP-Werte berechnet und gegen die Parasitenanzahl aufgetragen. 
In weiteren Untersuchungen zum Einfluss der Wirtsgewebe auf die real-time PCR wurde ermittelt, ob die geringere Sensitivität der real-time PCR durch Inhibitoren im Gewebe oder durch eine begrenzte Membrankapazität der DNA-Bindesäule während der DNA-Isolierung hervorgerufen wird. Dafür wurden einerseits jeweils $25 \mathrm{mg}$ Mausmuskulatur und Gehirngewebe mit Parasitenmengen von 100 und 1000 inokuliert, danach wurde die DNA isoliert und in der real-time PCR eingesetzt. Anderseits wurde jeweils DNA getrennt von den oben genannten Parasitenmengen ohne Mausgewebe und von Mausgewebe ohne Parasiten extrahiert. Die aus den Geweben und den Parasiten isolierte DNA wurde dann vereint und in mehreren realtime PCR Ansätzen amplifiziert.

Die Ergebnisse der real-time PCR zeigten eine nur geringfügig niedrigere Empfindlichkeit von Toxoplasma-DNA, wenn diese zusammen mit Mausmuskulatur oder Mausgehirn isoliert worden war im Vergleich zur Amplifikation von Parasiten-DNA, die getrennt aus Parasiten und Mausgewebe isoliert worden war (Abbildung 10). Dies deutete darauf hin, dass die Membrankapazität während der DNA-Isolierung von inokulierter Mausmuskulatur oder Mausgehirn lediglich in geringem Maße zur Hemmung der real-time PCR beiträgt. Da der Unterschied in den CP-Werten der real-time PCR von getrennten und ungetrennten DNA-Isolierungen gering und nicht signifikant war, ist anzunehmen, dass Inhibitoren im Gewebe der entscheidende Faktor für die geringere Sensitivität der 529-bp-basierenden PCR in Gegenwart von Wirtsgewebe darstellte. 
A.

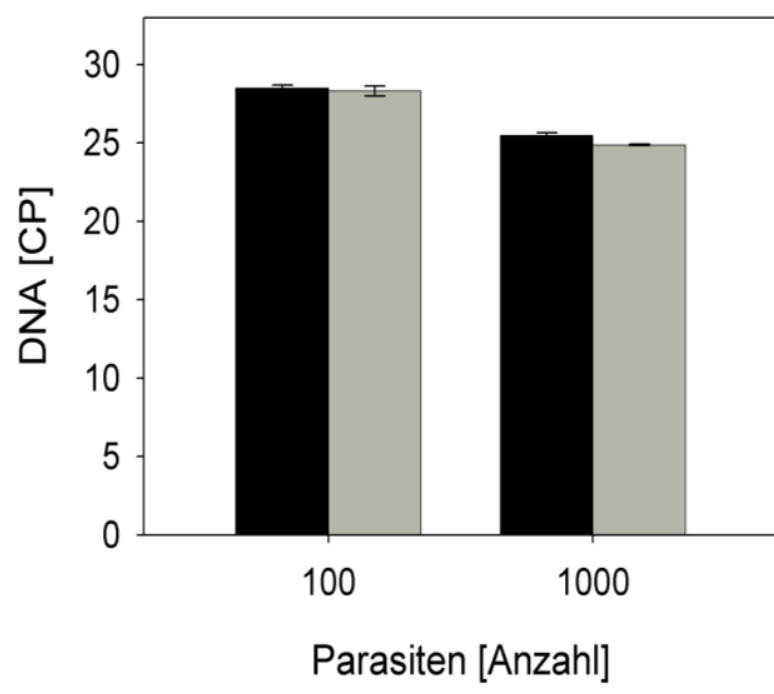

DNA-Isolierung Parasiten + Muskel DNA-Isolierung getrennt

B.

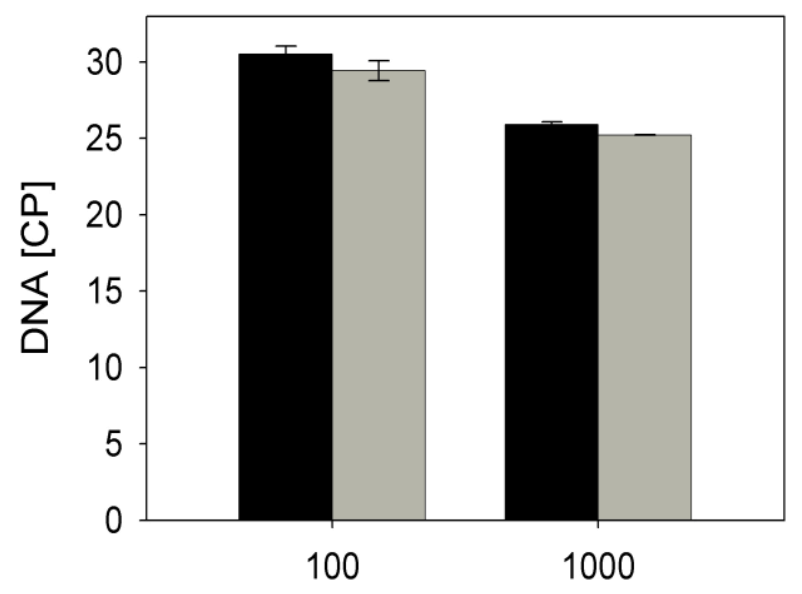

DNA-Isolierung Parasiten + Gehirn DNA-Isolierung getrennt

Parasiten [Anzahl]

Abbildung 10: Real-time PCR-Ergebnisse von Toxoplasma-DNA nach getrennter und ungetrennter Extraktion von Parasiten und Mausgewebe zur Untersuchung der Hemmung der PCR durch Inhibitoren im Mausgewebe oder durch Einfluss der Membrankapazität während der DNA-Isolierung. Mausmuskulatur (A) oder Mausgehirn (B) wurde mit Parasitenmengen von 1000 und 100 inokuliert, DNA extrahiert und in der real-time PCR amplifiziert. Andererseits wurde DNA getrennt aus Parasiten und Gewebe isoliert und für die real-time PCR gemischt. Die Parasitenanzahl wurde pro $25 \mathrm{mg}$ Gewebe angegeben. Nach mehreren PCR-Versuchen wurden die Mittelwerte +/- S.E:M. der CP-Werte berechnet. 


\subsection{Spezifität der 529-bp-real-time PCR}

Um die Spezifität der real-time PCR mit den Primern Toxo9/Toxo11 zu evaluieren, kamen genomische DNA-Präparationen von verschiedenen Coccidia-Parasiten (Neospora caninum, Hammondia hammondi, Besnoitia besnoiti, Sarcocystis gigantea, Isospora canis, Isospora felis) und die in dieser Arbeit verwendete ToxoplasmaDNA zum Einsatz. Dafür wurden zunächst die genomischen DNA-Präparationen von T. gondii und den anderen Coccidien mit den spezifischen Primern Coc1/Coc2 (Schares et al. 2008) für das universelle Gen der ribosomalen RNA der kleinen Untereinheit von Coccidien in der real-time PCR amplifiziert (Reaktionsbedingungen siehe Kapitel 2.2.10). Die Ergebnisse zeigten das Vorkommen von Coccidia-DNA in allen DNA-Proben (Abbildung 11). Mittels Agarose-Gelelektophorese wurde ein Amplifikat der erwarteten Größe von 294 bp bei allen Coccidien inklusive T. gondii erhalten (Abbildung 12). Anschließend wurden die gleichen DNA-Proben aus T. gondii und den anderen Coccidien mit den Primern Toxo9/Tox011 auf Amplifikation des 529-bp-Fragments untersucht (Reaktionsbedingungen siehe Kapitel 2.2.8.2). Die Ergebnisse zeigten, dass mit diesen Primern nicht nur ein Fragment von T. gondii amplifiziert wurde, sondern auch Amplifikate mit den genomischen DNAPräparationen von Sarcocystis gigantea, Isospora canis und Isospora felis entstanden (Abbildung 11). Allerdings zeigte die real-time PCR nach Amplifikation von T. gondii-DNA ein deutlich stärkeres Signal als nach Amplifikation der anderen Coccidien-DNAs. Durch Agarose-Gelelektrophorese wurde eine Übereinstimmung der Amplifikatgröße von 162 bp in T. gondii, S. gigantea, I. canis und I. felis nachgewiesen (Abbildung 12). Dagegen konnte DNA aus Neospora caninum, Hammondia hammondi und Besnoitia besnoiti mit den Primern Toxo9/Toxo11 nicht amplifiziert werden. 


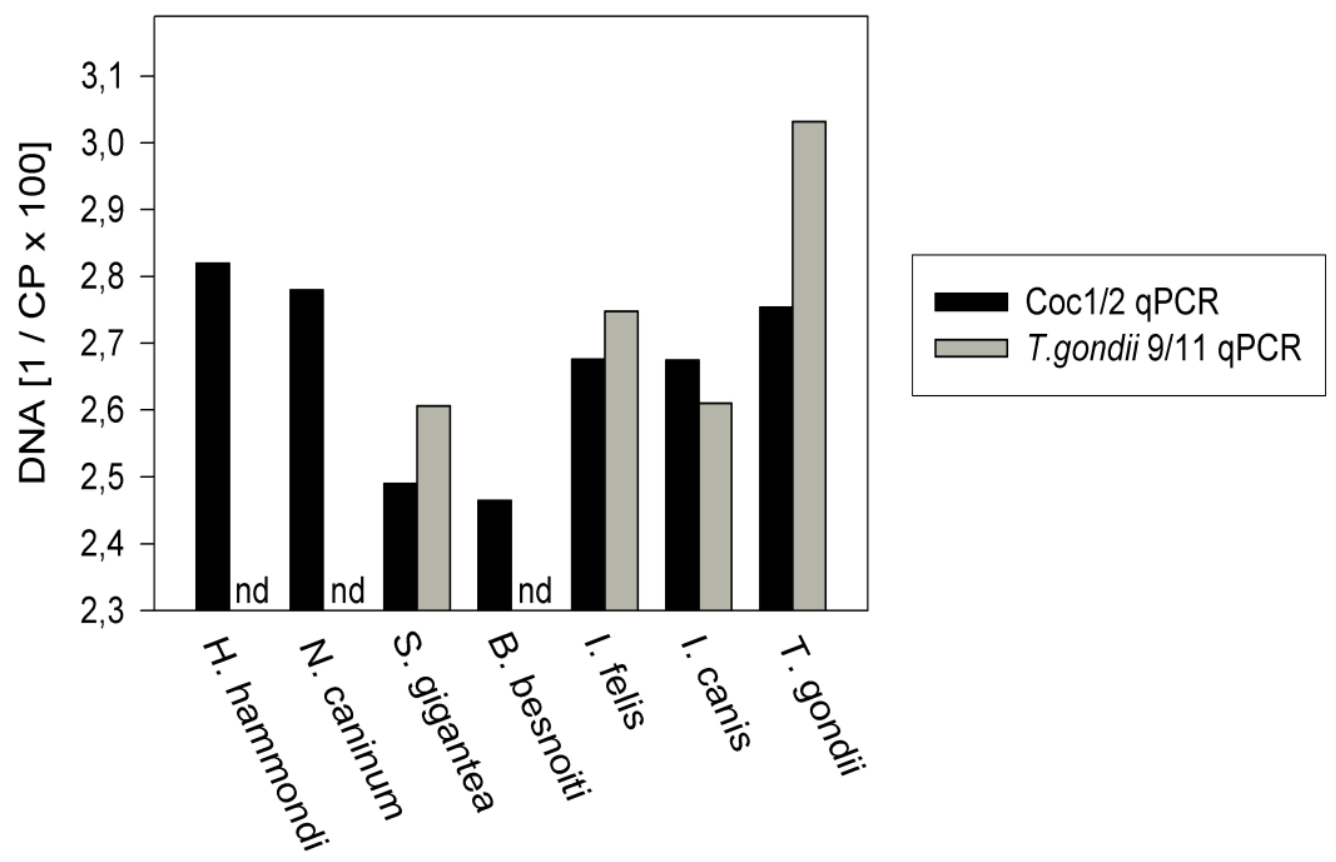

Abbildung 11: Real-time PCR mit Toxoplasma-DNA und DNA-Präparationen anderer Coccidien mit Primerpaaren Toxo9/Toxo11 und Coc1/Coc2 zur Überprüfung der Spezifität der real-time PCR. Genomische DNA-Präparationen verschiedener Coccidia-Parasiten und T. gondii-DNA wurden in der real-time PCR zunächst mit Primern Coc1/Coc2 und anschließend mit Primern Toxo9/Toxo11 amplifiziert. Die Mittelwerte der CP-Werte mehrerer PCR-Versuche wurden berechnet und als $(1 / \mathrm{CP})^{*} 100$ dargestellt. Nd: Nicht detektiert.

A.

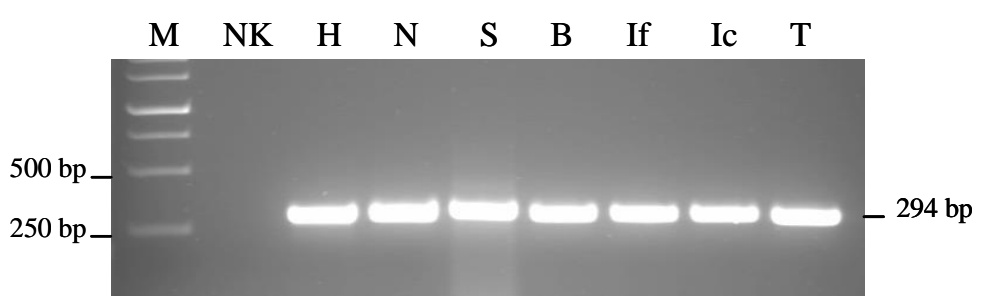

B.

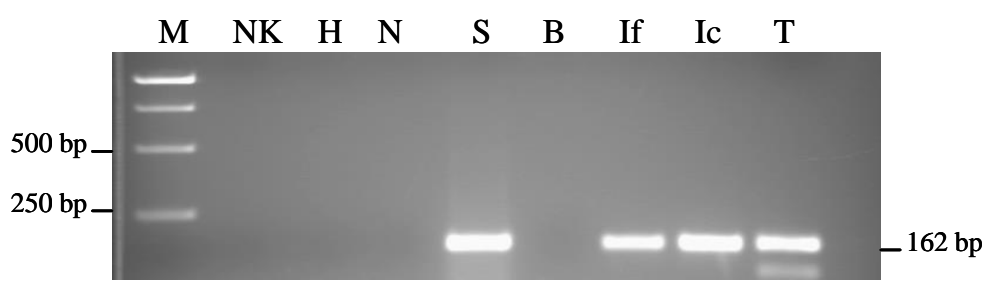

$\mathrm{H}$ : Hammondia hammondi

$\mathrm{N}$ : Neospora caninum

B: Besnoitia besnoiti

S: Sarcocystis gigantea

Ic: Isospora canis

If: Isospora felis

T: Toxoplasma gondii

Abbildung 12: Agarose-Gelelektrophorese der PCR-Produkte nach real-time PCR von T. gondii-DNA und DNAs von anderen Coccidien mittels Primern Coc1/Coc2 (A) und Primern Toxo9/Toxo11 (B). NK: PCR-Negativkontrolle $\left(\mathrm{H}_{2} \mathrm{O}\right)$. M:1kb DNA-Marker. 


\subsection{Nachweis von Toxoplasma gondii in Gewebeproben experimentell infizierter Schweine}

\subsubsection{Serologischer Nachweis der Toxoplasma-Infektion mittels Enzyme Linked Immunosorbent Assay (ELISA)}

Für die Versuche mit experimentell infizierten Schweinen wurden 10 Tiere mit verschiedenen Infektionsdosen von Toxoplasma-Oozysten infiziert, vier Tiere mit 106, drei Tiere mit $10^{5}$ und drei Tiere mit $10^{3}$ Oozysten. Als Negativkontrolle wurde ein nicht infiziertes Schwein verwendet. Um die erfolgreiche Infektion der Versuchstiere sicherzustellen, wurden die Tiere an unterschiedlichen Tagen nach Infektion bis zum Schlachttag serologisch mittels ELISA auf Toxoplasma-spezifische Antikörper untersucht. Die Infektion, die Blutabnahme und die Untersuchung der Tierseren wurden im Institut für Parasitologie, Tierärztliche Hochschule Hannover (Arbeitsgruppe von Prof. A. Tenter) durchgeführt. Die serologische Untersuchung ergab bei allen experimentell infizierten Schweinen einen positiven Toxoplasma-spezifischen Antikörpernachweis (Abbildung 13). Dabei zeigte der Zeitpunkt des Antikörperanstiegs eine gute Abhängigkeit von der Infektionsdosis: je größer die Infektionsdosis war, desto früher stiegen die Antikörpertiter gegen $T$. gondii in den Seren an (Abbildung 13). Das nicht infizierte Schwein (Schwein 19) wies keine Antikörper gegen Toxoplasma-Antigene im ELISA auf (Abbildung 13D). 
A.

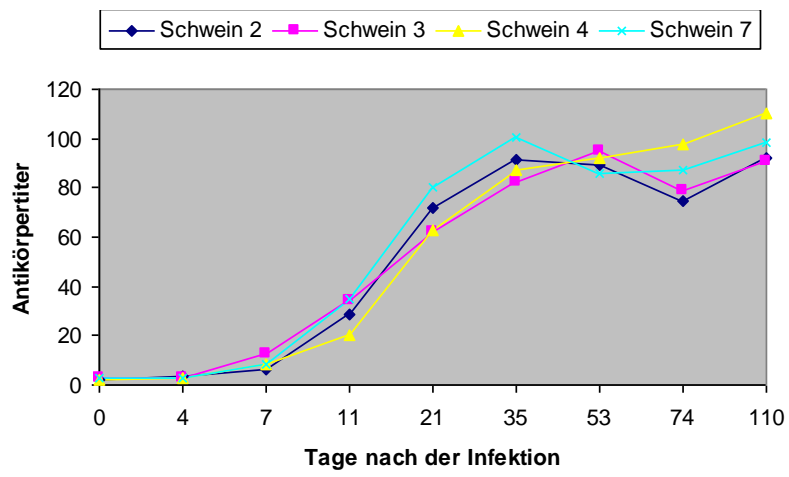

C.

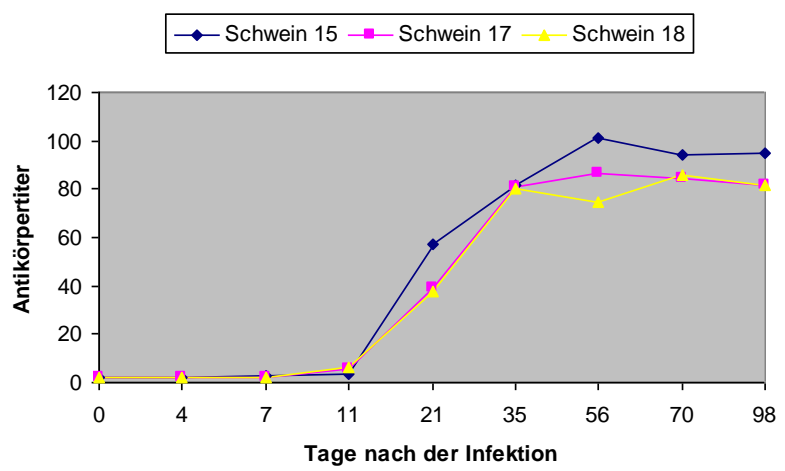

B.

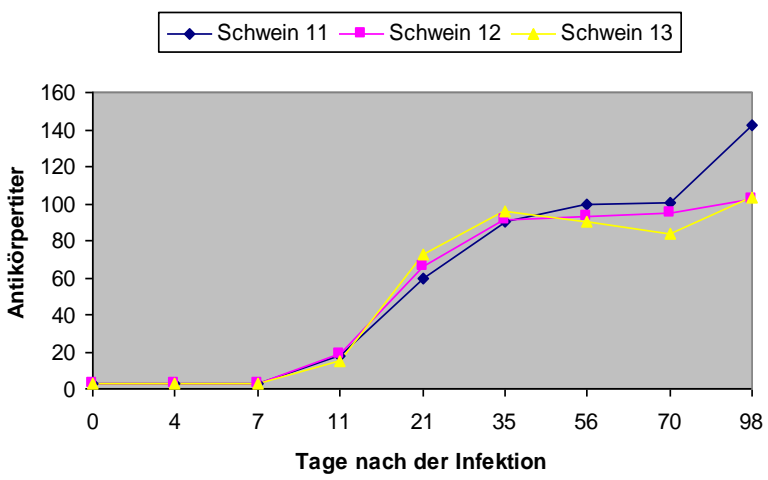

D.

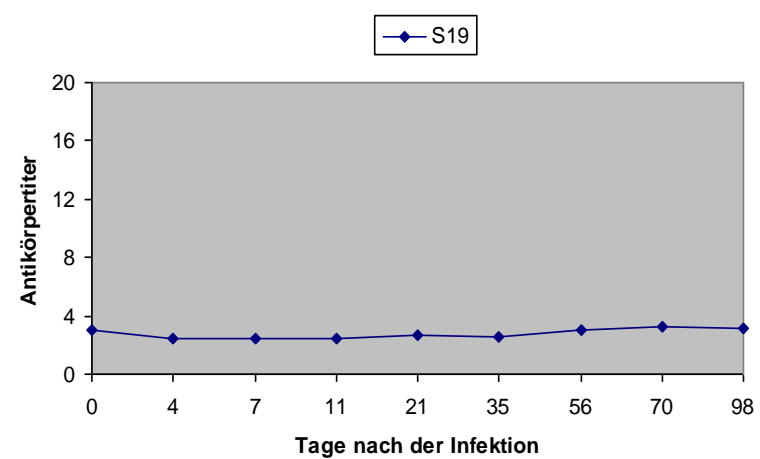

Abbildung 13: Serologische Untersuchung von experimentell mit Toxoplasma infizierten Schweinen mittels ELISA. Zehn Tiere wurden mit verschiedenen Infektionsdosen von Toxoplasma-Oozysten infiziert. Gruppe 1 enthielt 4 Schweine und wurde mit $10^{6}$ Oozysten infiziert (A), Gruppe 2 mit 3 Tieren wurde mit $10^{5}$ Oozysten (B) und Gruppe 3 mit 3 Tieren wurde mit $10^{3}$ Oozysten (C) infiziert. Ein nicht-infiziertes Schwein (Nr. 19) diente als Negativkontrolle (D). An unterschiedlichen Tagen nach der Infektion wurde Blut abgenommen und Seren mittels ELISA auf Antikörper gegen T. gondii untersucht. Die Graphen zeigen den Antikörperanstieg nach der Infektion mit T. gondii bis zum Tag, an dem die Tiere getötet wurden. 


\subsubsection{Nachweis von T. gondii-DNA in Schweinegewebe mittels real- time PCR}

Um T. gondii-DNA im Muskelgewebe der experimentell infizierten Schweine nachzuweisen, wurden die Versuchtiere getötet und verschiedene Gewebe mittels real-time PCR auf Vorliegen des Erregers untersucht. Es wurden jeweils mehrere Proben von Herz, Zunge, Oberschenkel, Vorderbein, Bauch und Gehirn untersucht. Von jedem Gewebe wurden $25 \mathrm{mg}$ abgewogen und die DNA extrahiert. Die real-time PCR wurde mit den Primern Toxo9/Toxo11 in Mehrfachansätzen durchgeführt. Als Positivkontrolle wurde $40 \mathrm{fg}$ Toxoplasma-DNA mitgeführt. Nach real-time PCR wurden in manchen Geweben schwache Amplifikate nachgewiesen und aufgrund der Schmelzkurvenanalyse als unspezifisch bewertet (nicht gezeigte Ergebnisse). Deshalb wurde ein Grenzwert berechnet, um den Infektionszustand der verschiedenen Schweinegewebe zu bestimmen. Dazu wurde der Mittelwert minus $2^{*} S D\left(2^{*}\right.$ Standardabweichung) der CP-Werte der Gewebe von Negativkontrollen berechnet und ein Grenzwert von 38,61 erhalten. CP-Werte, die größer waren als dieser Grenzwert, wurden als negativ und niedrigere CP-Werte als positiv bewertet (Abbildung 14). Die real-time PCR der Proben der experimentell infizierten Schweine zeigte, dass DNA des Erregers in verschiedenen Geweben, unter anderem in Muskelgeweben der infizierten Schweine, in unterschiedlicher Mengen nachgewiesen werden konnte (Abbildung 14). Dabei gab es keinen deutlichen Zusammenhang zwischen der Infektionsdosis und dem Nachweis von T. gondii-DNA im Gewebe. Das nicht-infizierte Kontrollschwein (Nr. 19) erwies sich in allen untersuchten Geweben als negativ (Abbildung 14). Darüber hinaus wurde auch in allen Geweben des mit 1000 Oozysten infizierten Schweins Nr. 18 der Grenzwert unterschritten und damit keines der Gewebe als Toxoplasma-positiv eingestuft. 


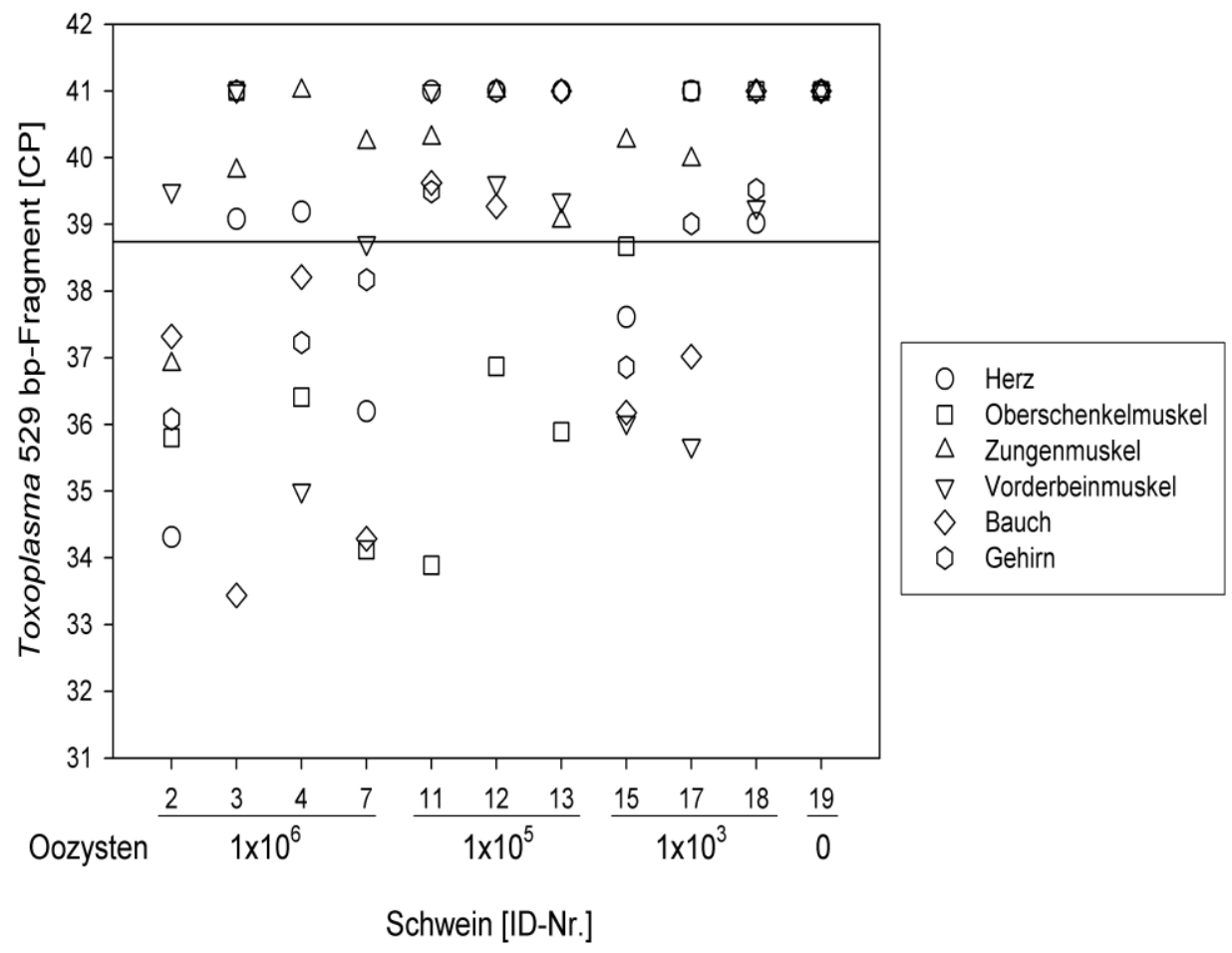

Abbildung 14: Nachweis von T. gondii-DNA in Schweinegeweben mittels real-time PCR mit Primern Toxo9/Toxo11. Zehn Tiere wurden experimentell mit verschiedenen Infektionsdosen von ToxoplasmaOozysten $\left(10^{6}, 10^{5}\right.$, und $\left.10^{3}\right)$ infiziert. Ein nicht infiziertes Schwein (Nr. 19) wurde als Negativkontrolle mitgeführt. Die Schweine wurden 98-110 Tage nach der Infektion getötet und Proben von verschiedenen Geweben der Schweine auf Toxoplasma-DNA untersucht. Dazu wurde DNA aus Gewebe extrahiert und das 529-bp-Fragment mittels real-time PCR in mehreren Versuchen amplifiziert. Aus dem Mittelwert der CP-Werte von Negativkontrollen minus 2*SD wurde ein Grenzwert von 38,61 berechnet. Der Graph zeigt die Verteilung der Parasiten-DNA in Schweinegewebe, die aufgrund des Grenzwertes als Toxoplasmapositiv (kleiner als Grenzwert) oder Toxoplasma-negativ (größer als Grenzwert) bewertet wurden.

Aus den in Abbildung 14 dargestellten Ergebnissen konnte die Infektionsverteilung in den unterschiedlichen Gewebearten der untersuchten Schweine bestimmt werden. Interessenterweise war die Häufigkeit von Toxoplasma gondii in bestimmten Muskelgeweben deutlich höher als z.B. im Gehirn oder Zunge. Dabei war der Oberschenkel mit ungefähr $70 \%$ besonders häufig positiv, eine hohe Infektionsrate zeigten auch Bauchmuskulatur mit 60\% sowie Gehirn und Vorderbeinmuskulatur mit jeweils 40\%. Das Herz war mit 30\% weniger häufig und die Zunge mit nur 10\% am seltensten betroffen (Abbildung 15). 


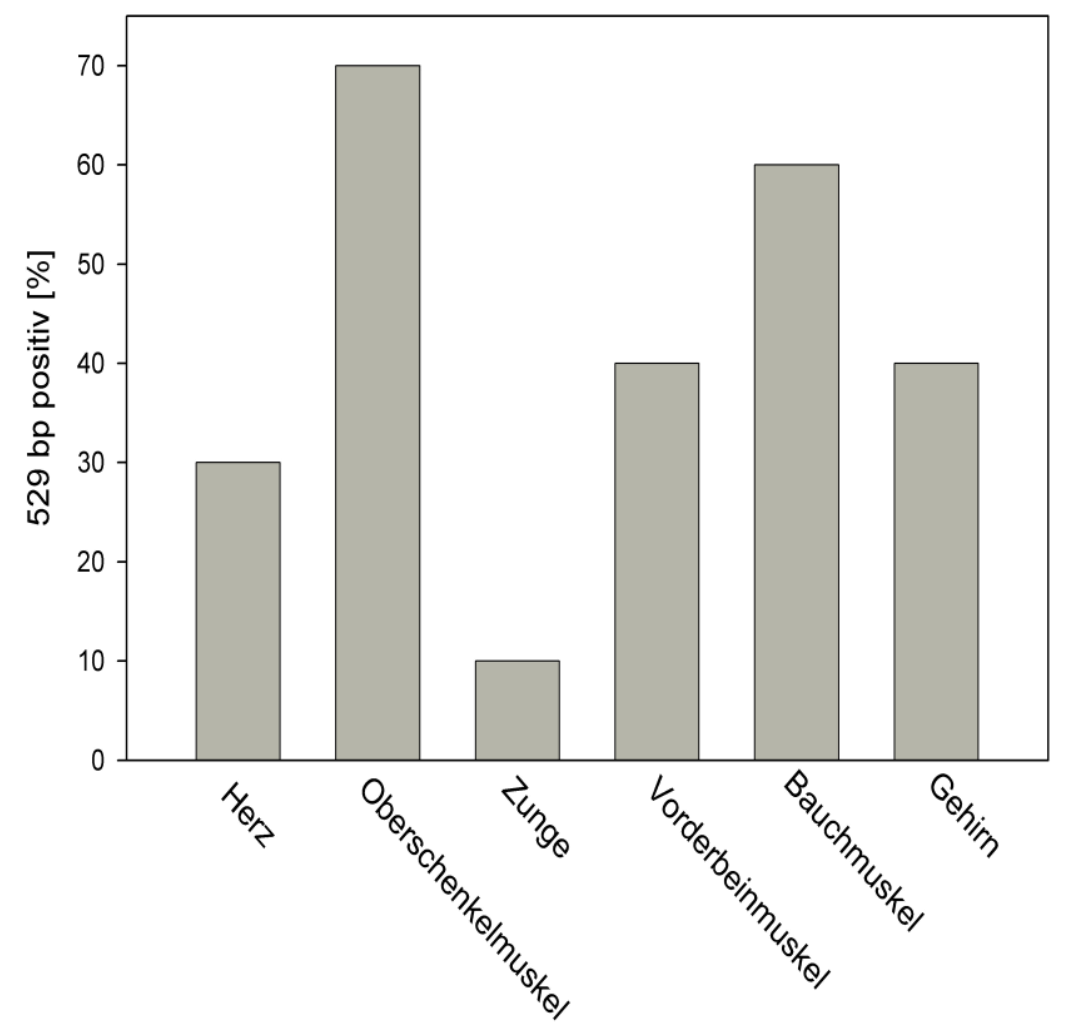

Abbildung 15: Verteilung von T. gondii-DNA in verschiedenen Gewebearten von experimentell infizierten Schweinen. Untersucht wurden Herz, Oberschenkel, Zunge, Bauch, Vorderbein und Gehirn auf das Vorhandensein des 529-bp-Fragments der T. gondii-DNA. Experimentelles Vorgeben wie in Abbildung 14 beschrieben.

Neben der Gewebeverteilung wurde anhand der unter Punkt 3.1.1 dargestellten Standardkurve auch berechnet, wie viele Parasiten die T. gondii-positiven Proben der Schweingewebe enthielten. Dazu wurden die CP-Werte der real-time PCR anhand der Standardgeradengleichung $\left(y=35,55-3,412^{*} x\right)$ in Parasitenmengen umgerechnet. Diese Quantifizierung zeigte mit Parasitenzahlen von 0,1 bis 4,1 in $25 \mathrm{mg}$ Gewebe deutliche Unterschiede im Vorhandsein von Parasiten-DNA (Tabelle 5). Dabei waren keine deutlichen Unterschiede in den Parasitenmengen in Abhängigkeit der Gewebeart festzustellen. Allerdings wurde in den Geweben, die besonders häufig positiv für $T$. gondii-DNA waren (Oberschenkelmuskulatur und Bauchmuskulatur), auch die größten Mengen von Parasiten-DNA in einzelnen Proben nachgewiesen. 
Tabelle 5: Quantifizierung von Toxoplasma gondii in Geweben der Versuchschweine

\begin{tabular}{cccccccc}
\hline & \multicolumn{7}{c}{ Parasitenanzahl / 25 mg Gewebe } \\
\cline { 2 - 8 } Infektionsdosis & $\begin{array}{c}\text { Schwein } \\
\text { (ID-Nr.) }\end{array}$ & Herz & Oberschenkel & Zunge & Vorderbein & Bauch & Gehirn \\
\hline \multirow{2}{*}{ 1Million } & 2 & 2,3 & 0,8 & 0,4 & - & 0,3 & 0,7 \\
Oozysten & 3 & - & - & - & - & 4,1 & - \\
& 4 & - & 0,5 & - & 1,4 & 0,2 & 0,3 \\
\multirow{2}{*}{$\mathbf{1 0 0 0 0 0}$ Oozys- } & 7 & 0,6 & 2,6 & - & 0,1 & 2,3 & 0,5 \\
ten & 11 & - & 3 & - & - & - & - \\
& 12 & - & 0,7 & - & - & - & - \\
$\mathbf{1 0 0 0}$ Oozysten & 13 & - & 0,8 & - & - & - & - \\
& 15 & 0,2 & 0,1 & - & 0,7 & 0,6 & 0,4 \\
& 17 & - & - & - & 0,9 & 0,4 & - \\
\hline
\end{tabular}

So konnte mittels real-time PCR in Schweinegewebe nach experimenteller Infektion mit $T$. gondii Parasiten-DNA relativ häufig im Muskelgewebe der infizierten Tiere unabhängig von der Infektionsdosis nachgewiesen werden.

\subsection{Nachweis von Toxoplasma gondii in Hühnern}

Als weiteres Nutztier, das für die Lebensmittel-bedingte Übertragung von T. gondii auf den Menschen von großer Bedeutung sein könnte, wurde in der vorliegenden Arbeit das Huhn untersucht. Dafür wurden 20 Hühner (8 Hühner im ersten Versuch und 12 im zweiten) experimentell mit verschiedenen Infektionsdosen von Toxoplasma-Oozysten im Institut für Parasitologie, Tierärztliche Hochschule Hannover (AG Prof. A. Tenter) infiziert. Als Negativkontrolle wurden 4 nicht infizierte Hühner (K1, K2, K3 und K4) verwendet. Die Tiere wurden nach der Infektion dekapitiert und jeweils mehrere Gewebeproben von Herz, Brustmuskel, Oberschenkelmuskel und Gehirn gewonnen. Außerdem wurde zu verschiedenen Zeitpunkten nach Infektion und am Schlachttag Serum für den Nachweis Toxoplasma-spezifischer Antikörper gewonnen. 


\subsubsection{Serologischer Nachweis der Toxoplasma-Infektion mittels des Direktagglutinationstests (Toxoscreen DA)}

Die serologische Untersuchung der experimentell infizierten Hühner des ersten und zweiten Infektionsversuchs zeigte einen positiven Antikörpernachweis gegen Toxoplasma-Antigen im Toxoscreen DA-Test (nicht gezeigte Ergebnisse). Die vier nichtinfizierten Hühner (K1, K2, K3 und K4) wiesen keine Antikörper gegen T. gondii auf.

\subsubsection{Nachweis von T. gondii-DNA in Hühnergeweben mittels real- time PCR}

Um T. gondii-DNA im Gewebe der Versuchshühner mittels real-time PCR nachzuweisen und zu quantifizieren, wurde die DNA aus den entnommenen Geweben extrahiert und durch real-time PCR mit den Primern Toxo9/Toxo11 untersucht. Wie bereits für die Versuche mit Schweinen beschrieben, wurden aus den CP-Werten der Gewebe nicht-infizierter Kontrolltiere der Mittelwert minus 2*SD als Grenzwert (CP = $38,74)$ bestimmt, um positive von negativen Amplifikationsergebnissen zu unterscheiden. Danach erwiesen sich nach Amplifikation von DNA aus Gewebeproben der Hühner des ersten Infektionsversuches nur vier Proben als T. gondii-positiv (Abbildung 16 A). Bei Huhn Nummer 6 konnte der Erreger im Gehirn, bei Huhn Nummer 9 und 13 in der Brustmuskulatur und bei Huhn Nummer 10 im Herz nachgewiesen werden. Dabei zeigte sich keine deutliche Relation zwischen dem Nachweis von T. gondii-DNA im Gewebe und der Infektionsdosis. Die nicht-infizierten Kontrollhühner (K1 und K2) erwiesen sich in allen untersuchten Geweben als negativ (Abbildung 16 A). Die real-time PCR der DNA aus Gewebeproben von Hühnern des zweiten Infektionsversuches zeigte, dass der Erreger in verschiedenen Muskelgeweben und/oder im Gehirn aller infizierten Hühner nachgewiesen wurde (Abbildung 16 B). Alle untersuchten Gewebe der nicht-infizierten Kontrolltiere (K1, K2, K3 und K4) waren Toxoplasma-negativ (Abbildung 16 B). Dabei war kein deutlicher Zusammenhang zwischen der Infektionsdosis und dem Nachweis von Toxoplasma-DNA festzustellen. Allerdings wurden in Gehirnen von zwei Hühnern der höchsten Infektionsrate (Hühner 22 und 46) die größten Mengen Toxoplasma-spezifischer DNA nachgewiesen (Abbildung $16 \mathrm{~B}$ ). Die Verteilung von Toxoplasma-DNA in den einzelnen Geweben war auch von der Infektionsdosis unabhängig (Abbildung 16 B). 
A.

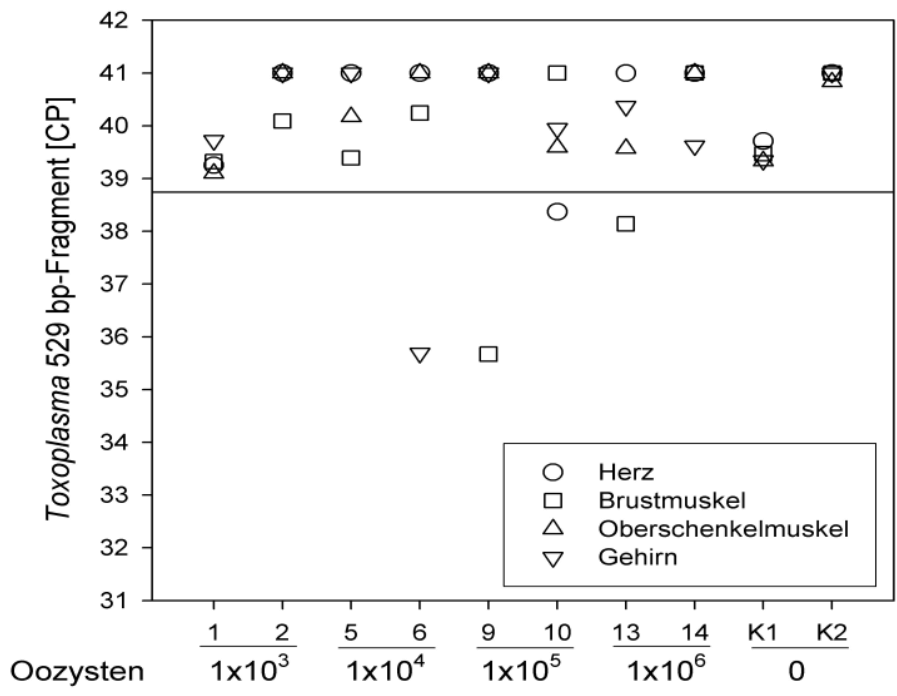

Huhn [ID-Nr.]

B.

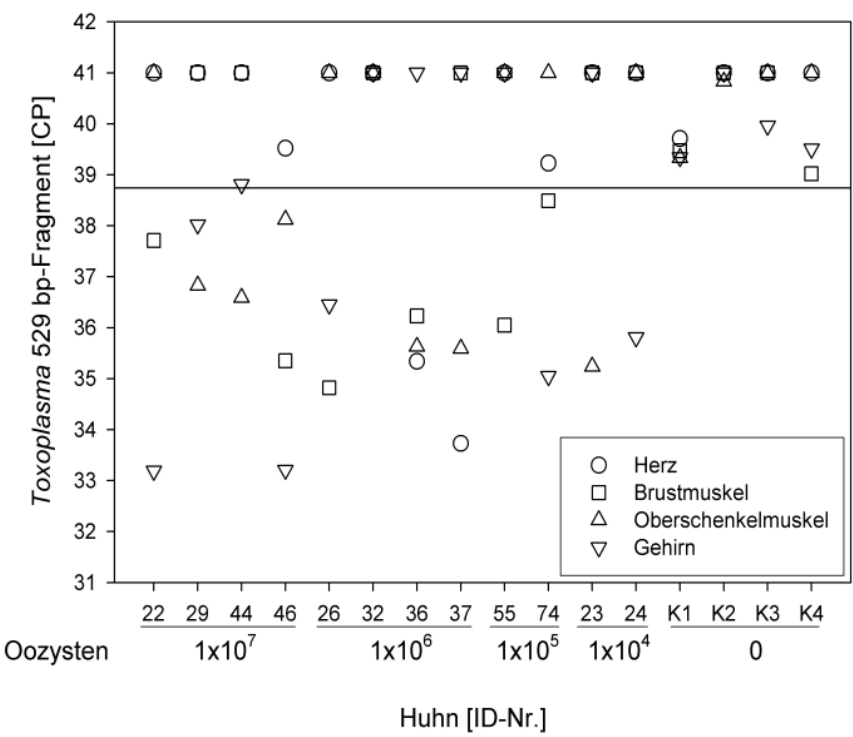

Abbildung 16: Nachweis von T. gondii-DNA in Geweben experimentell mit Toxoplasma infizierter Hühner mittels real-time PCR mit den Primern Toxo9/Toxo11. Zwanzig Tiere wurden experimentell mit verschiedenen Infektionsdosen von Toxoplasma-Oozysten infiziert. Davon wurden je 2 Hühner mit $10^{6}$, $10^{5}, 10^{4}$ und $10^{3}$ Toxoplasma-Oozysten im ersten Infektionsversuch (A) und jeweils 4 Tiere mit $10^{7}$ oder $10^{6}$ und je 2 Tiere mit $10^{5}$ oder $10^{4}$ Oozysten im zweiten Infektionsversuch (B) infiziert. Vier nicht infizierte Hühner (K1, K2, K3 und K4) wurden als Negativkontrolle verwendet. Die Hühner wurden 49 Tage (Versuch 1) bzw. 86 Tage (Versuch 2) nach der Infektion dekapitiert und mehrere Proben von verschiedenen Geweben gewonnen. Anschließend wurde aus den Geweben DNA extrahiert und eine real-time PCR auf Basis des 529-bp-Gens in mehreren Versuchen durchgeführt. Aus dem Mittelwert der CP-Werte der Negativkontrollen minus 2*SD wurde ein Grenzwert von 38,74 berechnet. Im Graphen sind anhand der CP-Werte der DNA-Amplifikationen positive DNA-Nachweise (kleiner als Grenzwert) bzw. negative DNA-Nachweise (größer als Grenzwert) dargestellt. 
Aus den in Abbildung 16 dargestellten Ergebnissen konnte die Infektionsverteilung in den untersuchten Gewebearten von Hühnern des zweiten Infektionsversuches bestimmt werden. Die Ergebnisse zeigten eine hohe Infektionsrate im Skelettmuskelgewebe sowie im Gehirn. Dabei enthielten Skelettmuskelgewebe wie Oberschenkel und Brustmuskulatur nach experimenteller Infektion mit T. gondii-Oozysten zu 50\% Toxoplasma-DNA. Die gleiche Infektionsrate zeigte auch das Gehirn. Herzgewebe war dagegen mit mehr als $20 \%$ deutlich weniger häufig positiv (Abbildung 17). Aufgrund der niedrigen Infektiosität der Toxoplasma-Oozysten bei Hühnern des ersten Infektionsversuchs und damit des geringeren Toxoplasma-DNA-Nachweises im Vergleich zur Häufigkeit des Toxoplasma-Nachweises bei Hühnern des zweiten Infektionsversuches wurden die Ergebnisse von Hühnergeweben des ersten Infektionsversuches in die Analyse der Gewebeverteilung nicht einbezogen.

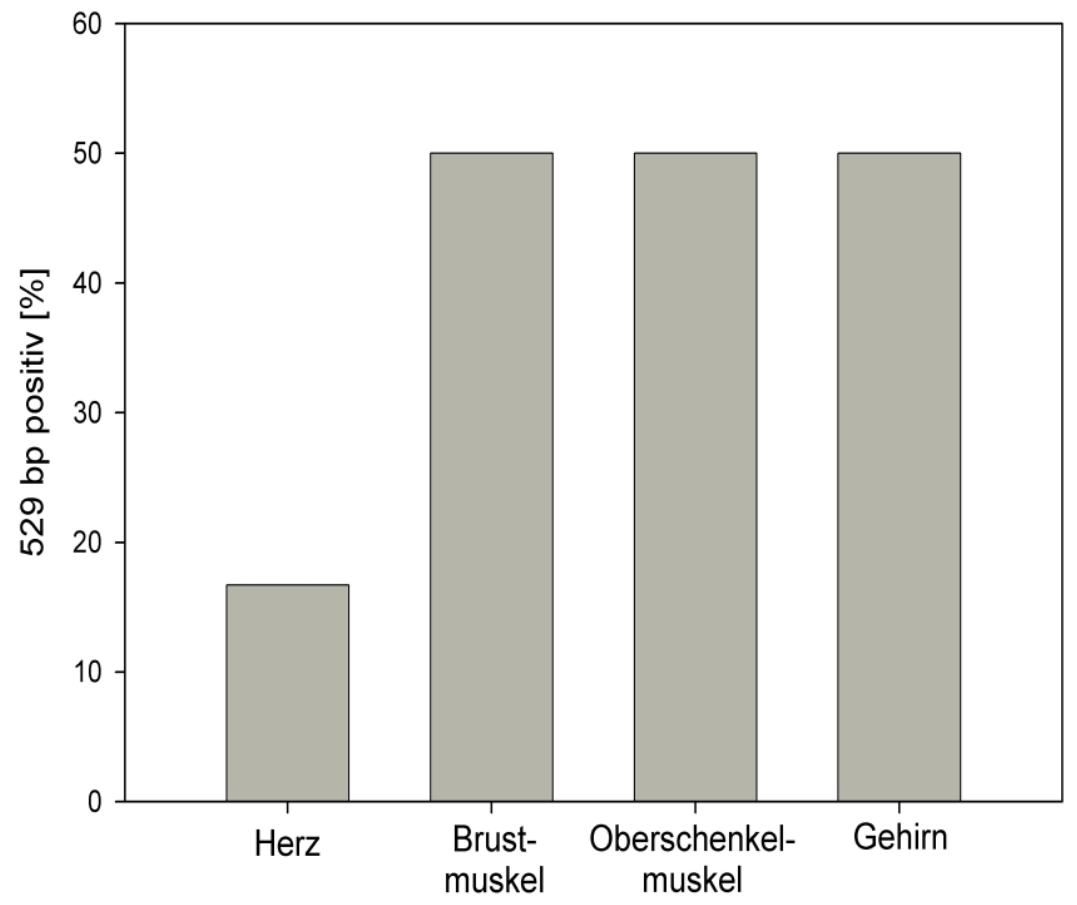

Abbildung 17: Häufigkeit des Nachweises von Toxoplasma-DNA in verschiedenen Geweben der experimentell mit $T$. gondii-Oozysten infizierten Hühner (Versuch 2). Untersucht wurden Herz, Oberschenkel, Brustmuskulatur und Gehirn auf das Vorhandensien des 529-bp-Fragments der T. gondii-DNA mittels real-time PCR. Experimentelle Einzelheiten sind in der Bildunterschrift von Abbildung 16 dargestellt. 
Anhand der unter Punkt 3.1.1 dargestellten Standardkurve wurde auf Basis der Geradengleichung (Abbildung 4, y=35,55-3,412*x) die Parasitenlast in den T. gondiipositiven Gewebeproben quantifiziert. Die Quantifizierung zeigte mit Parasitenzahlen von 0,1 bis 4,9 in $25 \mathrm{mg}$ Gewebe deutliche Unterschiede im Vorhandsein von Parasiten-DNA (Tabelle 6). Dabei wurden in Gehirngewebe die größten Mengen von Parasiten-DNA in einzelnen Proben nachgewiesen. Geringere Parasitenzahlen von 0,1 bis 1,6 enthielten Skelettmuskelgewebe (Oberschenkel und Brustmuskulatur). Herzgewebe, das weniger häufig positiv für $T$. gondii-DNA war, zeigte mittlere Mengen von Parasiten-DNA in den positiven Proben (Tabelle 6).

Tabelle 6: Quantifizierung von Toxoplasma gondii in Geweben der Versuchshühner

Parasitenanzahl / 25 mg Gewebe

Infektionsdosis

\begin{tabular}{|c|c|c|c|}
\hline $\begin{array}{l}\text { Huhn } \\
\text { (ID-Nr.) }\end{array}$ & Herz & Brustmuskel & Oberschenkel \\
\hline
\end{tabular}

\begin{tabular}{|c|c|c|c|c|c|}
\hline \multirow{5}{*}{10 Million Oozysten } & 22 & - & 0,3 & - & \multirow{2}{*}{$\begin{array}{l}4,9 \\
0,2\end{array}$} \\
\hline & 29 & - & - & 0,4 & \\
\hline & & & & & - \\
\hline & 44 & - & - & 0,5 & \\
\hline & 46 & - & 1,1 & 0,2 & 4,8 \\
\hline \multirow{5}{*}{1 Million Oozysten } & 26 & - & 1,6 & - & 0,5 \\
\hline & 32 & - & - & - & - \\
\hline & & & & & - \\
\hline & 36 & 1,2 & 0,6 & 0,9 & \\
\hline & 37 & 3,4 & - & 0,9 & - \\
\hline \multirow[b]{2}{*}{100000 Oozysten } & 55 & - & 0,7 & - & - \\
\hline & 74 & - & 0,1 & - & 1,4 \\
\hline \multirow[b]{2}{*}{10000 Oozysten } & 23 & - & - & 1,2 & - \\
\hline & 24 & - & - & - & 0,8 \\
\hline
\end{tabular}


So konnte mittels der real-time PCR Toxoplasma-DNA relativ häufig in Gehirn und Skeletmuskelgeweben der experimentell infizierten Hühner nachgewiesen werden. Dagegen konnte Toxoplasma-DNA nur in zwei Herzgewebeproben nachgewiesen werden.

\subsection{Nukleinsäure-basierte Untersuchung der Viabilität von T. gondii im Gewebe experimentell infizierter Hühner und Schweine}

In den bisher dargestellten Arbeiten wurde anhand der Amplifikation von Toxoplasma-DNA die Gewebeverteilung der Parasiten in experimentell infizierten Haustieren untersucht. Da DNA relativ stabil ist, lässt ein DNA-Nachweis keine Rückschlüsse auf das Vorhandsein lebender Parasiten in den Geweben zu. Um zu ermitteln, ob die nachgewiesene Parasiten-DNA von lebenden Toxoplasmen stammen könnte, sollte eine Methode etabliert wurde, um T. gondii-mRNA in Toxoplasma-DNA-positiven Gewebeproben mittels reverser Transkriptase-real-time PCR (RT-real-time PCR) und damit die Viabilität der Parasiten nachzuweisen und T. gondii-Tachyzoiten von Bradyzoiten zu differenzieren. Da RNA sehr instabil ist, kann sie mit hoher Wahrscheinlichkeit nur in lebenden Parasiten nachgewiesen werden. Für den Nachweis von Toxoplasma-mRNA im Gewebe der experimentell infizierter Hühner und Schweine wurde zunächst die Sensitivität der RT-real-time PCR bestimmt, dabei sollten spezifische mRNAs von Tachyzoiten und Bradyzoiten nachgewiesen werden. Dazu diente einerseits Mausgewebe, das mit bekannten Tachyzoiten-Mengen inokuliert wurde und andererseits eine Verdünnungsreihe von T. gondii-Gewebezysten aus Gehirnen infizierter Mäuse. Nach reverser Transkriptase der mRNA in cDNA wurden Sag1 als tachyzoitenspezifisches Gen (Burg et al. 1988), Bag1 als bradyzoitenspezifisches Gen (Bohne et al. 1995) und Actin als housekeeping-Gen von T. gondii durch real-time PCR amplifiziert. Die Actin-cDNA kann dabei sowohl in Tachyzoiten als auch in Bradyzoiten nachgewiesen werden. 


\subsubsection{Sensitivität des Sag1-mRNA-Nachweises}

Die Sensitivität der RT-real-time PCR zum Nachweis von Toxoplasma-mRNA in Wirtsgewebe wurde anhand einer Verdünnungsreihe von verschiedenen Tachyzoiten-Mengen $\left(10^{6}, 10^{5}, 10^{4}, 10^{3}, 10^{2}, 10\right)$ ohne Wirtsgewebe oder pro 25 mg Mausmuskulatur oder Gehirn evaluiert. RNA wurde von den vorgenannten Parasitenmengen mit oder ohne Wirtsgewebe isoliert und mittels Sensiscript Reverse Transkription Kits in cDNA umgeschrieben (Kapitel 2.2.7). Anschließend wurde cDNA des tachyzoitenspezifischen Sag1-Gens durch real-time PCR amplifiziert. Außerdem wurde cDNA von Toxoplasma-Actin als konstitutiv exprimiertes Gen als Kontrolle amplifiziert. Proben von Mausmuskulatur oder Gehirn ohne Parasiten sowie $\mathrm{H}_{2} \mathrm{O}$ wurden als Negativkontrollen eingesetzt. Die Spezifität der Amplifikate wurde anhand der Schmelzkurveanalyse sowie mittels Agarose-Gelelektrophorese (Kapitel 2.2.9.3) überprüft (nicht gezeigte Ergebnisse).

Actin-mRNA-positiver bzw. -negativer Proben wurden aufgrund eines Grenzwerts unterschieden, der als Mittelwert der CP-Werte von Negativproben minus $2{ }^{*} \mathrm{SD}$ $\left(\right.$ GrenzwertcP $=34,09 ;$ Grenzwert $\left._{\left(1 / \mathrm{CP}^{*} 100\right)}=2,94\right)$ berechnet wurde, dabei waren positive Proben größer als der Grenzwert $\left(1_{\left./ C P^{*} 100\right)}\right.$ und negative Proben kleiner (Abbildung 18). Die Ergebnisse zeigten, dass Toxoplasma-Actin-mRNA ab eine Menge von $10^{4}$ Parasiten nachgewiesen werden konnte, wenn RNA-Isolation und RT-real-time PCR mit Toxoplasma ohne Gewebe erfolgte (Abbildung 18). Toxoplasma-Actin-mRNA konnte auch in Proben mit $10^{5}$ oder mehr Parasiten pro $25 \mathrm{mg}$ Mausgewebe nachgewiesen werden (Abbildung 18). In manchen Proben (Muskel mit $10^{2}$ und Gehirn mit 104) wurde Actin-mRNA von Toxoplasma grenzwertig nachgewiesen. In Proben von Negativkontrollen (Gewebe ohne Parasiten 0) entstanden teilweise schwache unspezifische Amplifikate, aber Actin-cDNA wurde nicht amplifiziert (Abbildung 18). Die RT-real-time PCR von Toxoplasma-Actin zeigte eine gute Korrelation zwischen CP-Wert und Ausgangmenge von Parasiten, allerdings waren relativ große Menge von Tachyzoiten notwendig, um ein positives Signal zu erhalten. 


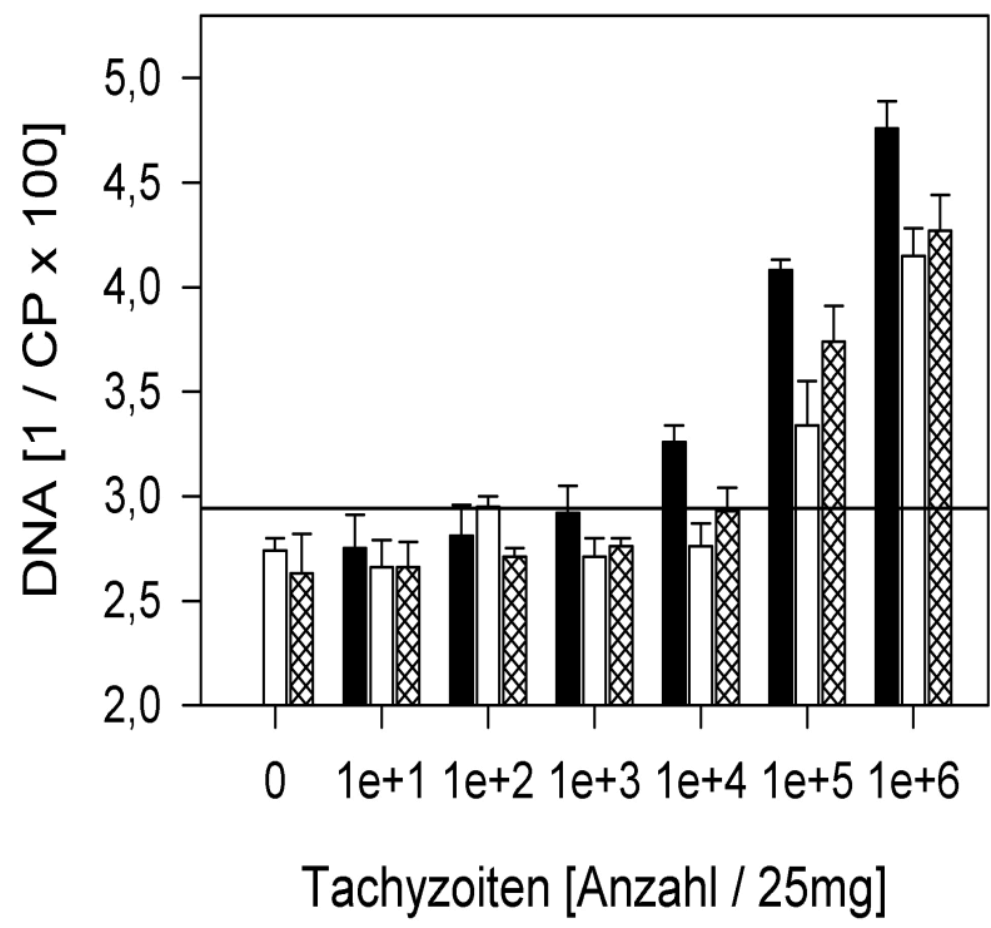

T. gondii

Abbildung 18: Nachweis von Actin-mRNA von T. gondii mittels RT-real-time PCR von verschiedenen Parasitenmengen $\left(10^{6}(1 e+6), 10^{5}(1 e+5), 10^{4}(1 e+4), 10^{3}(1 e+3), 10^{2}(1 e+2), 10(1 e+1)\right)$ ohne und mit Mausgewebe. Mausmuskulatur oder Gehirn wurden mit definierten Parasitenmengen versetzt, RNA isoliert, cDNA synthetisiert und Actin-cDNA mittels real-time PCR amplifiziert. Dargestellt sind die Mittelwerte +/- S.E.M. des Kehrwertes der CP-Werte multipliziert mit 100. Als Grenzwert des mRNANachweises wurde der Mittelwert der Negativproben plus ${ }^{*} \mathrm{SD}$ festgelegt, Werte oberhalb dieses Grenzwertes wurden als positiv gewertet.

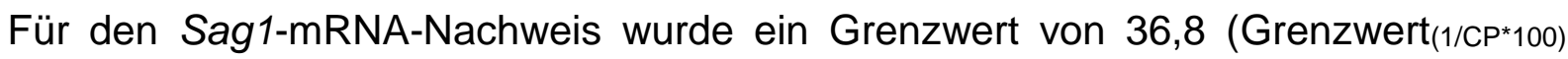
= 2,72), wie bereits für Actin beschrieben, berechnet. Sag1-positive Proben lagen über dem Grenzwert, der den Infektionszustand aufzeigte (Abbildung 19). Im Gegensatz zur Actin-mRNA wurde Sag1-mRNA mittels RT-real-time PCR in Proben ohne Wirtsgewebe bereits ab eine Parasitenmenge von 10 nachgewiesen (Abbildung 19). Außerdem konnte Sag1-mRNA in Proben nachgewiesen werden, die $10^{4}$ oder mehr Parasiten pro $25 \mathrm{mg}$ Gewebe enthielten. Die Amplifikation von Sag1-cDNA zeigte, dass die Sensitivität der RT-real-time PCR bei Proben mit Wirtsgewebe deutlich geringer war als bei isolierten Parasiten. Bei geringeren Parasitenmengen oder den Negativkontrollen (Gewebe ohne Parasiten, 0 ) wurden zum Teil geringfügig unspezifische Amplifikate, aber nicht das erwartete Fragment amplifiziert (nicht gezeigte 
Ergebnisse). Im Vergleich zur Actin-mRNA wurde Sag1-mRNA von T. gondii in geringeren Ausgangmengen von Parasiten deutlich nachgewiesen.

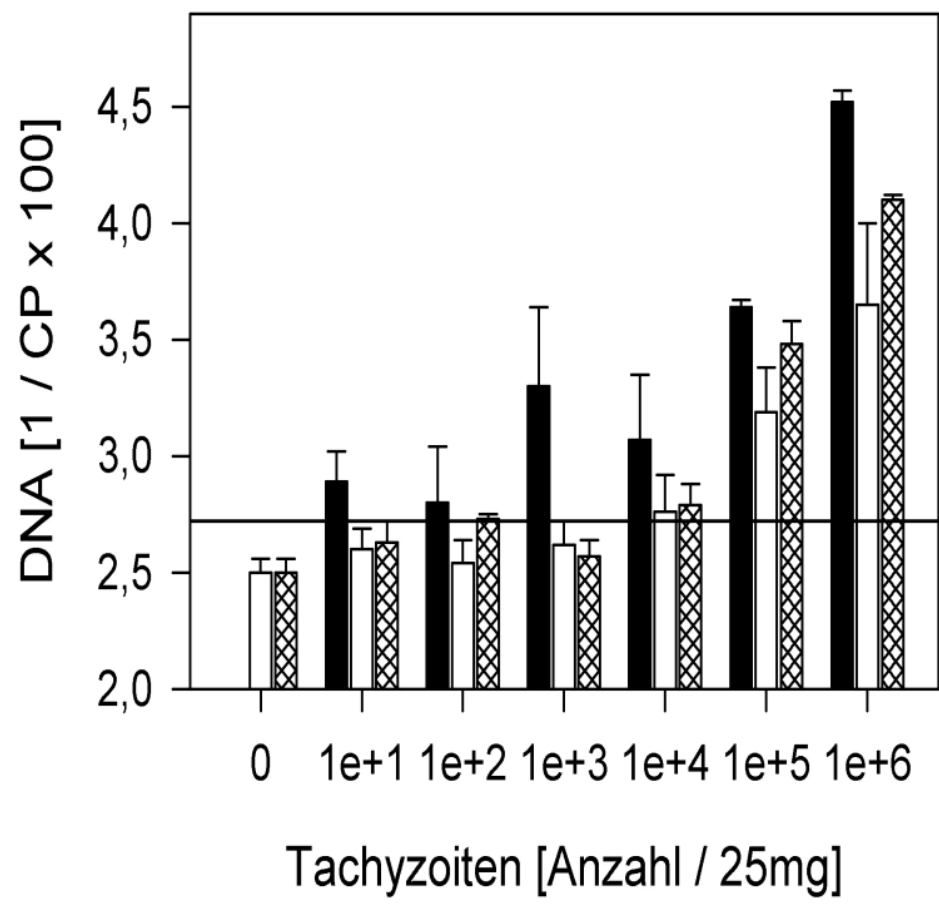

T. gondii

Muskel $+T$. gondii

Gehirn + T. gondii

Abbildung 19: Nachweis von Sag1-mRNA von T. gondii mittels RT-real-time PCR von verschiedenen Parasitenmengen $\left(10^{6}(1 e+6), 10^{5}(1 e+5), 10^{4}(1 e+4), 10^{3}(1 e+3), 10^{2}(1 e+2), 10(1 e+1)\right)$ ohne und mit Mausgewebe. Mausmuskulatur oder Gehirn wurden mit definierten Parasitenmengen versetzt, RNA isoliert, cDNA synthetisiert und Sag1-cDNA mittels real-time PCR amplifiziert. Dargestellt sind die Mittelwerte +/- S.E.M. des Kehrwertes der CP-Werte multipliziert mit 100. Als Grenzwert des mRNANachweises wurde der Mittelwert der Negativproben plus ${ }^{*} \mathrm{SD}$ festgelegt, Werte oberhalb dieses Grenzwertes wurden als positiv gewertet. 


\subsubsection{Sensitivität des Bag1-mRNA-Nachweises}

Die Sensitivität der RT-real-time PCR zum Nachweis von T. gondii-mRNA wurde anhand einer Verdünnungsreihe von T. gondii-Gewebezysten aus Gehirnen infizierter Mäuse evaluiert. Für diesen Versuch wurden Gehirne der mit Toxoplasma-Zysten infizierten Mäuse wie in den Methoden beschrieben (Kapitel 2.2.11) gewonnen, homogenisiert und aus der Gehirnsuspension wurde eine Verdünnungsreihe von unterschiedlicher Zystenanzahl (10, 1, 0.1, 0.01, 0.001 und 0.0001 Zysten) in PBS hergestellt, RNA isoliert und cDNA mittels des Sensiscript Reverse Transkription Kits synthetisiert (Kapitel 2.2.7). Gehirn einer nicht infizierten Maus sowie $\mathrm{H}_{2} \mathrm{O}$ wurden als Negativkontrolle eingesetzt. Weil sich die Parasiten im Gewebe innerhalb von Zysten im Bradyzoitenstadium befinden, wurde cDNA des bradyzoitenspezifischen Bag1Gens mit Hilfe der real-time PCR amplifiziert. Zudem wurde cDNA von ToxoplasmaActin als konstitutiv exprimiertes Gen als Kontrolle und Toxoplasma-Sag1 amplifiziert. Die Spezifität der Amplifikate wurde anhand der zugehörigen Schmelzkurvenanalyse sowie mittels Agarose-Gelelektrophorese (Kapitel 2.2.9.3) überprüft (nicht gezeigte Ergebnisse)

Um Actin-mRNA-positive bzw. -negative Proben zu unterscheiden, wurde ein Grenzwert als Mittelwert der CP-Werte von Negativproben minus 2*SD (GrenzwertcP $=37,44$; Grenzwert $\left.\left(1 / \mathrm{CP}^{*} 100\right)=2,74\right)$ berechnet, dabei waren positive Proben größer als der Grenzwert $\left(1 / \mathrm{CP}^{*} 100\right)$ und negative Proben kleiner (Abbildung 20). Amplifikation der Actin-cDNA aus T. gondii-Gewebezysten in der real-time PCR zeigte, dass Actin-mRNA ab eine Menge von 0,1 Toxoplasma-Zysten oder mehr nachgewiesen werden. In der Negativkontrolle (Gehirngewebe nicht-infizierter Maus) sowie in Proben mit sehr geringer Ausgangmenge von Toxoplasma-Zysten entstanden schwache unspezifische Amplifikate. 


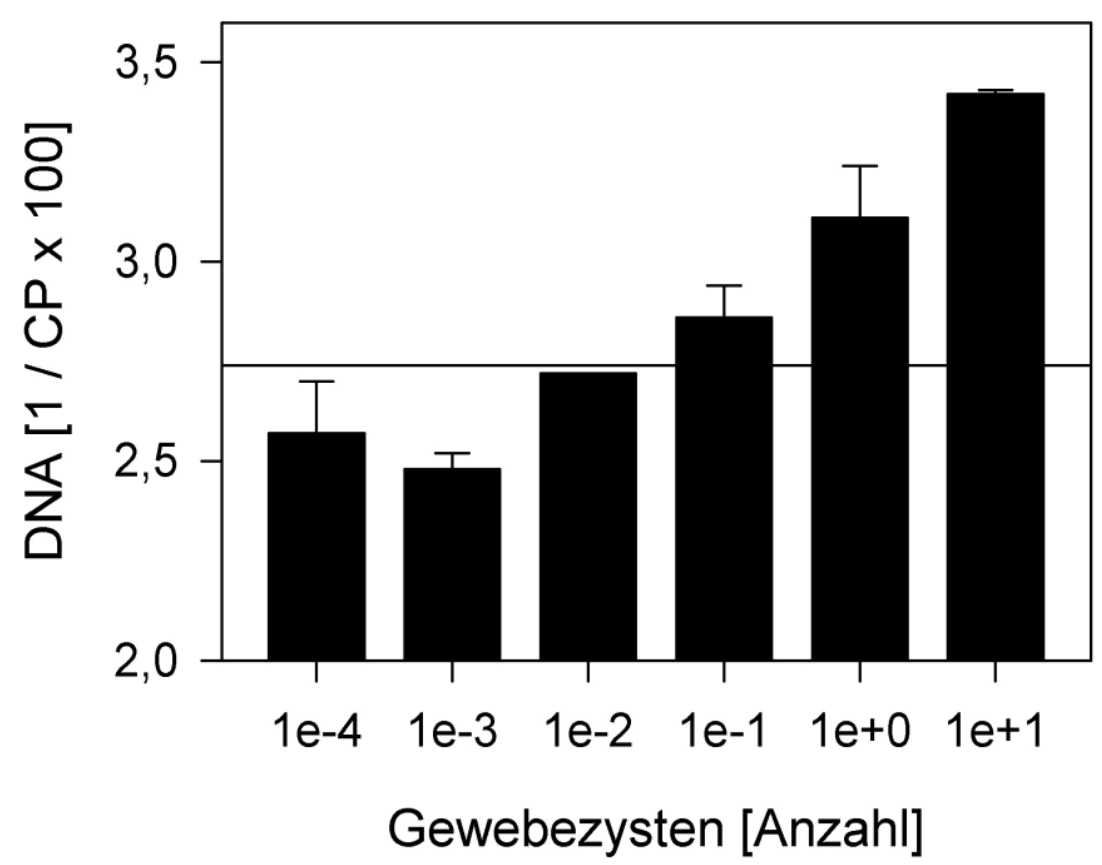

Abbildung 20: Nachweis von Actin-mRNA von Toxoplasma gondii mittels RT-real-time PCR einer Verdünnungsreihe von T. gondii-Gewebezysten (10 (1e+1), 1 (1e+0), $0.1(1 \mathrm{e}-1), 0.01$ (1e-2), 0.001 (1e-3) und 0.0001 (1e-4) Zysten) aus Gehirnen infizierter Mäusen. Gehirngewebe wurde gewonnen, homogenisiert, die Zystenanzahl pro 30 $\mu$ l Suspension unter dem Mikroskop ausgezählt und es wurde anschließend eine Verdünnungsreihe von den vorgenannten Zystenanzahlen in PBS hergestellt. Danach wurde RNA isoliert, cDNA synthetisiert und Actin-cDNA mittels real-time PCR amplifiziert. Dargestellt sind die Mittelwert +/- S.E.M. des Kehrwertes der CP-Werte multipliziert mit 100. Als Grenzwert des mRNANachweises wurde der Mittelwert der Negativproben plus $2^{*}$ SD festgestellt, Werte oberhalb dieses Grenzwertes wurden als positiv gewertet.

Für den Bag1-mRNA-Nachweis aus Toxoplasma-Gewebezysten wurde, wie bereits für Actin beschrieben, ein Grenzwert von 36,53 (Grenzwert $\left._{\left(1 / \mathrm{CP}^{*} 100\right)}=2,75\right)$ berechnet. Ähnlich den Ergebnissen der Actin-mRNA konnte Bag1-mRNA mittels RT-real-time PCR ab einer Menge von 0,01 T. gondii-Zysten oder mehr nachgewiesen werden. In der Probe mit 0,01 Zysten wurde Bag1-mRNA allerdings nur grenzwertig nachgewiesen. Dagegen entstanden in Proben mit geringeren Ausgangmengen von Toxoplasma-Zysten sowie in der Negativkontrolle keine spezifischen Amplifikate. Die RT-realtime PCR von Toxoplasma-Bag1 zeigte eine gute Korrelation zwischen CP-Wert und Ausgangmenge der Gewebezysten. 


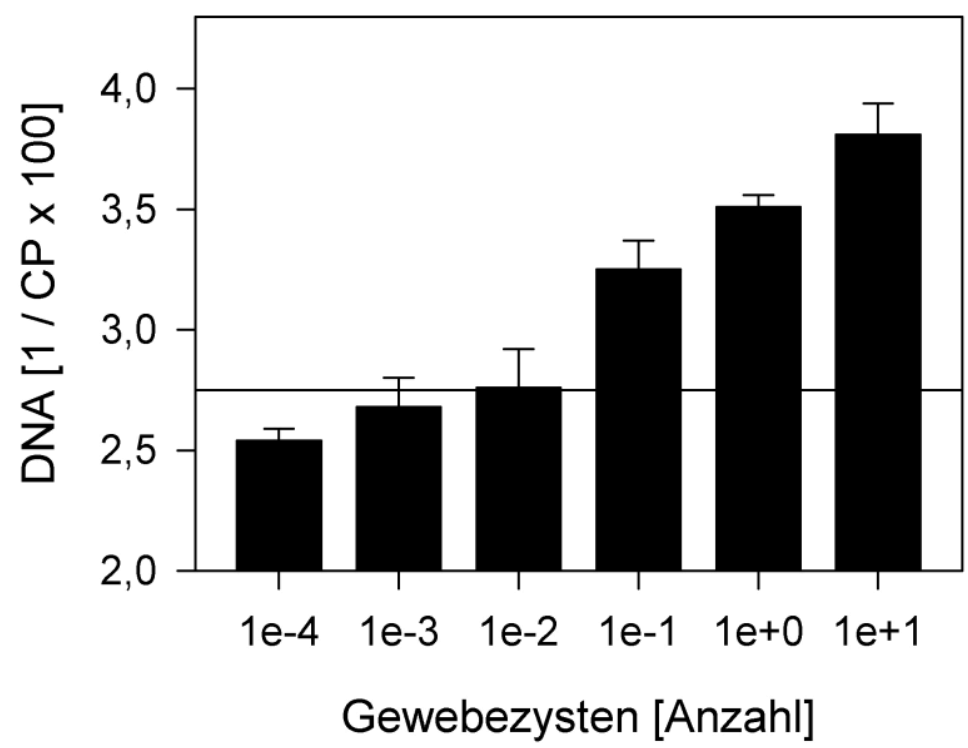

Abbildung 21: Nachweis von Bag1-mRNA von Toxoplasma gondii mittels RT-real-time PCR einer Verdünnungsreihe von T. gondii-Gewebezysten (10 (1e+1), 1 (1e+0), $0.1(1 \mathrm{e}-1), 0.01(1 \mathrm{e}-2), 0.001$ (1e-3) und 0.0001 (1e-4) Zysten) aus Gehirnen infizierter Mäusen. Dargestellt sind die Mittelwerte +/- S.E.M. des Kehrwertes der CP-Werte multipliziert mit 100. Als Grenzwert des mRNA-Nachweises wurde der Mittelwert der Negativproben plus $2^{*} \mathrm{SD}$ festgelegt, dabei waren positive Proben größer als dieser Grenzwert. Experimentelle Einzelheiten sind wie in der Abbildung 20 beschrieben.

In diesem Versuch wurde neben Actin- und Bag1-mRNA von T. gondii die Sag1mRNA mit den Primern sag1 for/sag1 rev amplifiziert, die spezifisch das tachyzoitenspezifische Sag1-Gen, aber nicht das bradyzoitenspezifische Bag1-Gen amplifizieren, um die Stadienspezifität im Gewebe sicherzustellen. Hier dienten isolierte Tachyzoiten mit Ausgangmenge von $10^{6}$ Parasiten als Positivkontrolle sowie Gehirn einer nicht-infizierten Maus als Negativkontrolle. Wie bereits beschrieben, wurde ein Grenzwert von 37,31 (Grenzwert $\left.\left(1 / \mathrm{CP}^{*} 100\right)=2,68\right)$ bestimmt. Die Ergebnisse zeigten, dass außer der Positivkontrolle zwei Proben (mit 0,0001 und 1 Zysten) schwach über dem Grenzwert lagen (Abbildung 22). Allerdings konnte anschließend anhand der zugehörigen Schmelzkurveanalyse gezeigt werden, dass diese Amplifikate unspezifisch waren, da die erhaltenen Schmelzkurven nicht denen der Positivkontrolle entsprachen (nicht gezeigte Ergebnisse). In den anderen Proben wurde keine Sag1cDNA amplifiziert (Abbildung 22). 


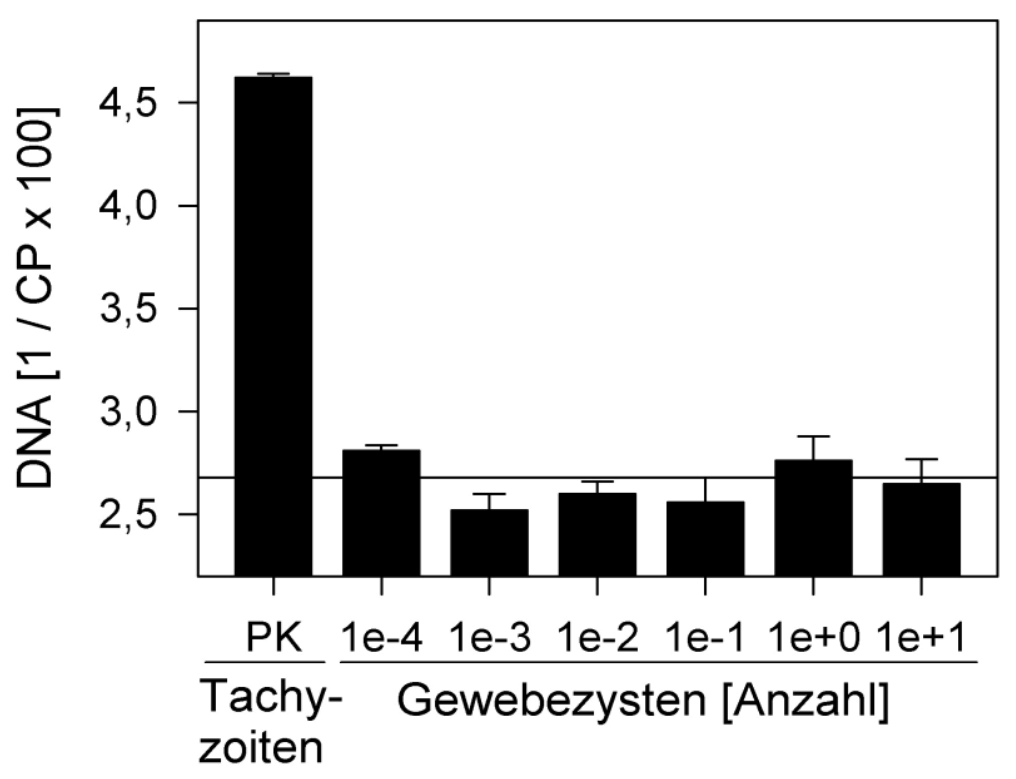

Abbildung 22: RT-real-time PCR von T. gondii -Sag1-mRNA mit den Primern sag1 for/sag1 rev von definierten Mengen von T. gondii-Gewebezysten (10 (1e+1), 1 (1e+0), 0.1 (1e-1), 0.01 (1e-2), 0.001 (1e3) und 0.0001 (1e-4) Zysten) aus Gehirnen infizierter Mäusen. Dargestellt sind die Mittelwerte +/- S.E.M. des Kehrwertes der CP-Werte multipliziert mit 100. Als Grenzwert des mRNA-Nachweises wurde der Mittelwert der Negativproben plus $2^{*} \mathrm{SD}$ festgelegt, dabei waren positive Proben größer als dieser Grenzwert. Experimentelle Einzelheiten sind in der Abbildung 20 dargestellt. PK: Positivkontrolle.

Die Ergebnisse der RT-real-time PCR in Gehirnen infizierter Mäuse zeigten, dass Toxoplasma-mRNA deutlich ab Ausgangmenge von 0,1 Toxoplasma-Zysten im infizierten Gehirn nachgewiesen werden konnte. Dagegen war mit niedrigeren Zystenmengen kein positives Signal zu erhalten.

\subsubsection{Nachweis von Toxoplasma-mRNA im Gewebe experimentell infizierter Hühner und Schweine}

In Gewebeproben der in dieser Arbeit untersuchten experimentell infizierten Schweine und Hühner wurde Toxoplasma-DNA mittels 529-bp-Fragment-basierter real-time PCR nachgewiesen (Kapitel 3.4.2 und 3.5.1). Um zu ermitteln, ob die nachgewiesene Parasiten-DNA von lebenden Toxoplasmen stammen könnte, wurden die Toxoplasma-DNA-positiven Gewebeproben auf Vorhandsein von Toxoplasma-mRNA untersucht. Dazu dienten verschiedene positive Gewebeproben der untersuchten Schweine und Hühner, die die höchste Parasitenanzahl enthielten. Außerdem 
wurden Gewebeproben der nicht-infizierten Tiere (Huhn: K1, K2, K3 und Schwein Nr. 19) mitgetestet. Von den ausgewählten Gewebeproben wurde RNA isoliert und in cDNA mittels des Sensiscript Reverse Transkription Kits umgeschrieben (Kapitel 2.2.7). Anschließend wurde cDNA des bradyzoiten-spezifischen Bag1-Gens und des Actin-Gens durch real-time PCR amplifiziert. Als Positivkontrolle diente die bereits in Kapitel 3.6.2 vorgenannte cDNA-Lösung von 10 Zysten. Die Spezifität der Amplifikate wurde mittels Agarose-Gelelektrophorese überprüft (Abbildung 23). Die CP-Werte der RT-real-time PCR von Bag1-mRNA sind in den folgenden Tabellen aufgeführt (Tabelle 7, 8). Die Ergebnisse zeigten in den Toxoplasma-DNA-positiven Gewebeproben unspezifische Amplifikate im Vergleich zur Positivkontrolle, dabei wurde mit Agarose-Gelelektrophorese ein Fragment der erwarteten Größe von 101 bp nur in der Positivkontrolle, aber nicht in den Gewebeproben der beiden experimentell infizierten Tierarten nachgewiesen (Hühnerergebnisse: Abbildung 23). Außerdem unterschieden sich die CP-Werte zwischen nicht-infizierten Kontrolltieren und Toxoplasma-infizierten Tieren nicht grungsätzlich. Ähnliche Ergebnisse von unspezifischen Amplifikaten ergab die Amplifikation von Actin-cDNA in allen untersuchten Gewebeproben (nur in Hühnergeweben untersucht) im Vergleich zur Positivkontrolle (nicht gezeigte Ergebnisse). So konnte T. gondii-mRNA in Gewebeproben der experimentell infizierten Hühner und Schweine nicht detektiert werden.

Tabelle 7: CP-Werte der RT-real-time PCR zur Untersuchung des Vorhandenseins von T. gondii-mRNA (Bag1-mRNA) in verschiedenen Geweben der experimentell infizierten Hühner und nicht-infizierten Kontrollhühner

\begin{tabular}{c|c|c|c|c|c|c}
\hline Huhn & Infektion & $\mathbf{H}_{\mathbf{2}} \mathbf{O}$ & Positivkontrolle & Gehirn & Brustmuskel & Oberschenkel \\
\hline & & $>41$ & 31,32 & - & - & - \\
K 1 & - & & & 26,97 & 27,27 & n.b. \\
K 2 & - & & & 33,22 & 32,52 & n.b. \\
K 3 & - & & & 32,14 & 32,11 & n.b. \\
H 22 & + & & & 27,8 & n.b. & n.b. \\
H 23 & + & & & n.b. & n.b. & 27,74 \\
H26 & + & & & n.b. & 27,63 & n.b. \\
H46 & + & & & 33,81 & 33,87 & n.b. \\
H74 & + & & & 29,03 & n.b. & n.b. \\
\hline
\end{tabular}

n.b: nicht bearbeitet 
Tabelle 8: CP-Werte der RT-real-time PCR zur Untersuchung des Vorhandenseins von T. gondii-mRNA (Bag1-mRNA) in verschiedenen Geweben der experimentell infizierten Schweine und des nicht-infizierten Kontrollschweins

\begin{tabular}{c|c|c|c|c|c}
\hline Schwein & Infektion & $\mathbf{H}_{2} \mathbf{O}$ & Positivkontrolle & Gehirn & Oberschenkel \\
\hline & & $>41$ & 27,86 & - & - \\
S 19 & - & & & 28,45 & 26,2 \\
S 2 & + & & & 27,48 & 26,46 \\
S 7 & + & & & 27,68 & 26,1 \\
S 11 & + & & & n.b. & 27,05 \\
S 15 & + & & & 27,89 & n.b. \\
\hline
\end{tabular}

n.b: nicht bearbeitet

A.

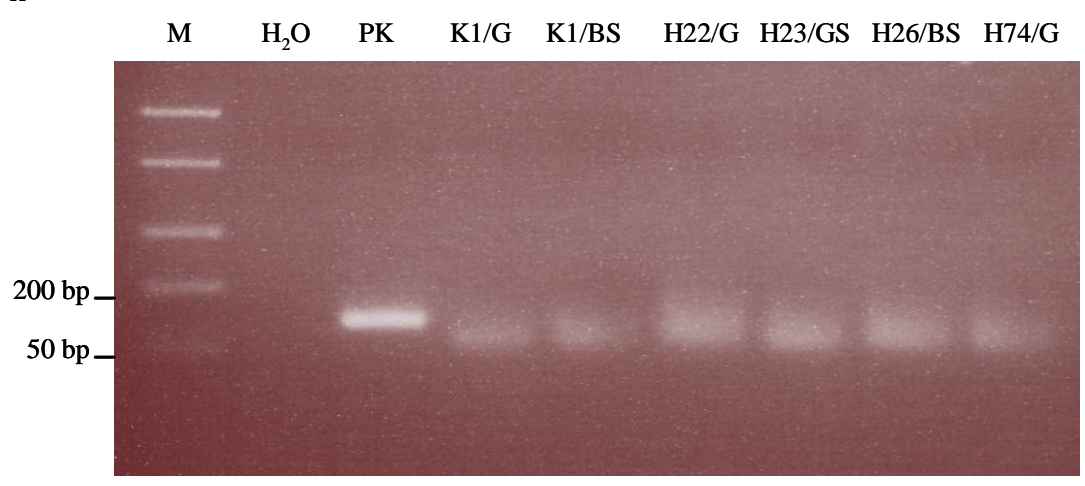

B.

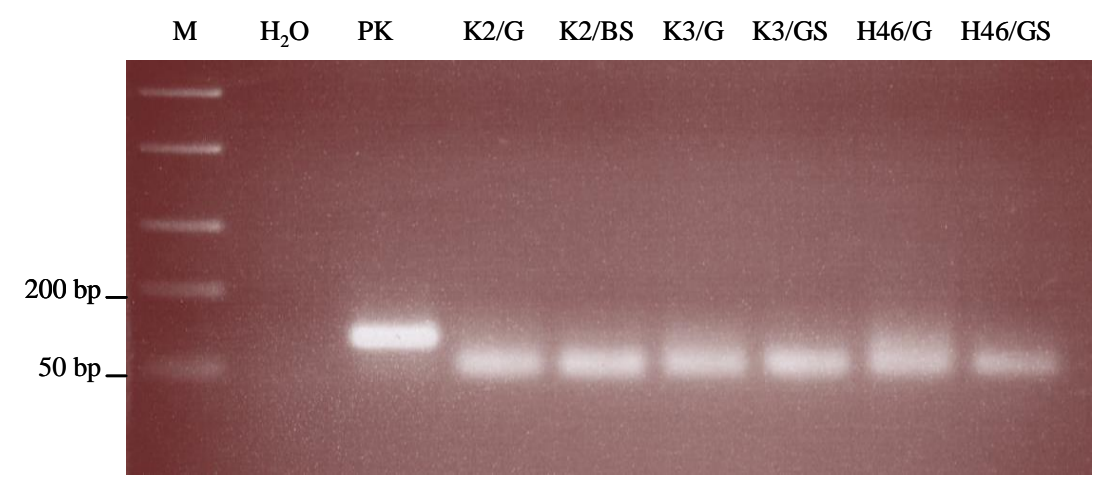

Abbildung 23: Agarose-Gelelektrophorese von Amplifikation der RT-real-time PCR von verschiedenen Hühnergeweben zur Untersuchung der Vitalität der bereits im Hühnergewebe durch DNA-Amplifikation nachgewiesenen Parasiten. RNA wurde isoliert, in CDNA umgeschrieben und das Bag1-Gen durch realtime PCR untersucht. PK: Positivkontrolle, K: Kontrolle (nicht infizierte Hühner), H: Huhn+ ID-Nr, G: Gehirn, GS: Oberschenkel, BS: Brustmuskulatur. 


\section{Diskussion}

Die orale Aufnahme von Toxoplasma-Zysten durch den Verzehr von rohem oder ungenügend gegartem Fleisch oder Fleischprodukten landwirtschaftlicher Nutztiere stellt eine wichtige Infektionsquelle für den Menschen mit T. gondii dar. Die Gewebezysten können vermutlich jahrlang im Wirtsgewebe lebensfähig bleiben, z.B. sind in Schweinefleisch Gewebezysten in der Lage, mehr als zwei Jahre zu persistieren (Dubey et al. 1998). Die Anzahl der bei verschiedenen Wirtsspezies vorkommenden Gewebezysten und ihre Verteilung in den unterschiedlichen Wirtsgeweben sind abhängig von der Tierart. So kommen Toxoplasma-Zysten am häufigsten bei Schweinen, Schafen und Ziegen vor, weniger häufig bei Geflügel, Pferden und Jagdtieren und bei Rindern sind sie nur sehr selten (Tenter et al. 2000). Mehrere Studien zeigten, dass T. gondii bei Schweinen, Schafen und Ziegen die Tendenz aufweist, häufiger in Skelett- und Herzmuskulatur zu persistieren als in anderen Organen (Dubey et al. 1998; Tenter 2009).

In der vorliegenden Arbeit wurde ein Beitrag geleistet, die Bedeutung des Verzehrs von rohem oder nicht ausreichend erhitztem Fleisch von Schweinen und Hühnern für die Übertragung von Toxoplasma gondii auf den Menschen zu bestimmen. Um das Infektionsrisiko für Menschen durch Verzehr von Zysten-haltigem Fleisch einzuschätzen, wurde das Vorhandsein und die Verteilung von T. gondii in Gehirn und unterschiedlichen Muskelgeweben von experimentell infizierten Schweinen und Hühnern mittels real-time PCR untersucht. Außerdem sollte auch die Vitalität des Parasiten in dem untersuchten Gewebe ermittelt werden.

\subsection{Nachweis von Toxoplasma-DNA in Mausgewebe und Bestimmung von Parasitenmengen mittels real-time PCR}

Die real-time PCR wird als ein sehr empfindliches spezifisches und schnelles Verfahren für den Nachweis und die Quantifizierung von Toxoplasma gondii in verschiedenen klinischen Proben von Menschen und Tieren (z.B. Gewebe, Liquor, Amnionflüssigkeit oder Blutproben) angesehen (Jauregui et al. 2001; Reischl et al. 2003; Su et al. 2010). Verschiedene Targets wurden als Basis für die real-time PCR verwendet, dazu gehört das von Homan et al. (2000) entdeckte 529-bp-Fragment, 
das im Genom von Toxoplasma gondii in hoher Kopienzahl von 200 bis 300 vorhanden ist. Infolgedessen ist die auf Grundlage dieser Repeat-Region basierende realtime PCR sensitiver als die mit Targets, die nur in geringer Kopienzahl oder als Einzelkopie im Genom der Erreger vorkommen. Außerdem konnte mit der real-time PCR auf der Basis des 529-bp-Fragments T. gondii-DNA in Proben mit geringen Parasitenmengen nachgewiesen werden (Edvinsson et al. 2006). Aufgrund dieser Informationen wurde in dieser Arbeit eine real-time PCR auf Basis des 529-bpFragments unter Verwendung des Fluoreszenfarbstoffes SYBR Green zum Nachweis und Quantifizierung von Toxoplasma gondii in Gewebe von Schwein und Huhn etabliert.

Die in dieser Arbeit verwendete real-time PCR erfolgte als erstes mit den mit verschiedenen bekannten Tachyzoiten-Mengen versetzten Mausgeweben (Gehirn oder Muskulaturgewebe), um die Sensitivität der real-time PCR zum Nachweis von T. gondii im Gewebe zu untersuchen und eine Standardkurve aus bekannten Parasitenmengen zu erstellen. Da die geeignete Auswahl von Primern ebenso wie auch die Auswahl des Targets in der PCR wichtig ist, wurden dafür zwei Primerpaare, Toxo9/Toxo11 und Toxo4/Toxo5 getestet. Mit den Primern Toxo9/Toxo11 ließ sich T. gondii-DNA in Mengen zwischen 2,5 und 104 Tachyzoiten pro 25 mg Mausgewebe nachweisen. Dagegen ließen sich 10 bis $10^{4}$ Tachyzoiten pro $25 \mathrm{mg}$ Mausgewebe mit den Primern Toxo4/Toxo5 nachweisen. Im Vergleich konnten Jauregui et al. (2001) mittels einer real-time PCR von 4 bis 3,7 x 105 Bradyzoiten/g in versetzten Schweinemuskulaturproben nachweisen. Diese Sensitivität ist höher als die hier beschriebene real-time PCR (2,5 Tachyzoiten/ 25 mg oder 100 Tachyzoiten/g mit den Primern Toxo9/Toxo11). Jauregui et al. (2001) benutzten dabei eine real-time PCR (TaqMan-PCR) mittels ITS1-abgeleiteten Primern und fluorogenen Sonden. Dagegen war die PCR-Sensitivität in einer Studie von Warnekulasurija et al. (1998) relativ gering. Hier wurde mit Hilfe einer nested PCR (P30-Gen) bis zu einer Menge von $5 \times 10^{3}$ Trophozoiten/g in gespikten Fleischproben nachgewiesen. Diese geringere Sensitivität wurde auf eine hohe Salzkonzentration in den Fleischproben zurückgeführt.

Die Empfindlichkeit der real-time PCR auf Basis des 529-bp-Fragments war mit den Primern Toxo9/Toxo11 deutlich höher als mit den Primern Toxo4/Toxo5. In der Studie von Reischl et al. (2003) gelang mittels real-time PCR der Nachweis von $20 \mathrm{fg}$ Toxoplasma-DNA, das entspricht weniger als einem Toxoplasma-Tachyzoiten. Im 
Gegensatz dazu erfolgte in Untersuchungen von Homan et al. (2000) die Amplifikation des 529-bp-Fragments mittels der Primer Tox04/Toxo5 und konnte minimal vier Tachyzoiten pro $200 \mu \mathrm{l}$ humaner Amnionflüssigkeit nachweisen. Die geringere Sensitivität der real-time PCR mit den Primern Toxo4/Toxo5 liegt vermutlich daran, dass diese Primer das komplette 529-bp-Fragment amplifizieren, während Primer Toxo9/Toxo11 nur 162 bp von der 529-bp-Repeat-Region amplifizieren. Dabei umfasst die Amplifikation mit Primern Tox04/Toxo5 auch das sogenannte T-reiche DNA-Segment am 3`-Ende, das als besonders problematisch bei der Amplifikation angesehen wird. Dieses Segment hat einen negativen Einfluss auf die Taq DNAPolymerase und ebenso auf die Effizienz der Amplifikation (Reischl et al. 2003). Aufgrund dieser Informationen wurden die weiteren Untersuchungen nur mit den Primern Toxo9/Toxo11 durchgeführt.

\subsection{Weitere Untersuchungen zur Sensitivität und Spezifität des Toxoplasma-Nachweises in Wirtsgewebe mittels PCR}

Anhand der auf Basis des B1-Gens etablierten nested PCR zum Nachweis von T. gondii-DNA in Wirtsgewebe (Muskulatur oder Gehirn) konnten nur bis zu 10 oder mehr Tachyzoiten pro 25 mg Gewebe detektiert werden. Dagegen war die real-time PCR zum Nachweis des repetitiven 529-bp-Fragments mit einer Nachweisgrenze von bis zu 2,5 oder mehr Tachyzoiten pro 25 mg Gewebe deutlich sensitiver. Diese unterschiedliche Sensitivität zwischen nested PCR und real-time PCR kann durch die unterschiedliche Kopienzahl der beiden untersuchten Gene im Genom des Erregers erklärt werden. Während das B1-Gen im Genom von T. gondii 35 Mal vorkommt, ist die 529-bp-Region mit 200 bis 300 Kopien vorhanden (Homan et al. 2000; Reischl et al. 2003; Edvinsson et al. 2006; Calderaro et al. 2006).

Der Einfluss von Wirtsgewebe auf die Sensitivität der T. gondii-529-bp real-time PCR wurde ebenfalls überprüft. Dabei war der Nachweis von T. gondii-DNA aus unterschiedlichen Parasitenmengen ohne Gewebe deutlich empfindlicher (etwa drei Crossing Points früher) als der aus gleichen Parasitenmengen mit Wirtsgewebe. Schätzungen zufolge entspricht ein Unterschied von etwa 3,5 Crossing Points in PCR-Reaktionen einer zehnfach höheren Ausgangskonzentration des DNATemplates (Reischl et al. 2003). Darum zeigen die Ergebnisse, dass das Wirtsgewebe einen negativen Einfluss auf die T. gondii-529-bp real-time PCR ausübte, deren 
Sensitivität etwa zehnfach geringer war als jene von Parasiten ohne Gewebe. Es war daher auch von Interesse zu klären, ob die geringere Sensitivität der real-time PCR durch Inhibitoren im Gewebe verursacht wird oder durch eine begrenzte Membrankapazität der DNA-Bindesäule während der DNA-Isolierung. Die Ergebnisse zeigten deutlich, dass die Membrankapazität während der DNA-Isolierung von inokulierter Mausmuskulatur oder Mausgehirn nur in geringem Maße zur verminderten Sensitivität der real-time PCR beitrug. Da der Unterschied in den CP-Werten der real-time PCR nach Amplifikation gleicher Mengen von Parasiten-DNA, die entweder zusammen mit dem Wirtsgewebe isoliert wurden oder getrennt isoliert und nachträglich gemischt wurden, gering und nicht signifikant war, ist zu vermuten, dass Inhibitoren im Wirtsgewebe eine hemmende Wirkung auf die Sensitivität der 529-bpbasierten PCR in Gegenwart von Wirtsgewebe hatten. Bei Verwendung des LightCycler-Systems hat möglicherweise das Vorhandensein großer Mengen von unspezifischer Gewebe-DNA eine hemmende Wirkung auf den Nachweis von Parasiten-DNA (Bellete et al. 2003; Edvinsson. 2004). Bellete et al. (2003) konnten zeigen, dass der Nachweis von Parasiten-DNA beeinträchtigt wurde, wenn die unspezifische DNA in LightCycler-Kapillaren eine bestimmte Menge überschritten hatte.

Die Spezifität der real-time PCR wurde anhand der Amplifikation von genomischer DNA verschiedener Coccidia-Parasiten (Neospora caninum, Hammondia hammondi, Besnoitia besnoiti, Sarcocystis gigantea, Isospora canis, Isospora felis) und der in dieser Arbeit verwendeten Toxoplasma-DNA ermittelt. Mit den Primern Coc1/Coc2 konnten alle Coccidia-DNA einschließlich Toxoplasma-DNA nachgewiesen werden. Außer der zu erwarteten Amplifikation von T. gondii-DNA traten Kreuzreaktionen mit den Primern Toxo9/Toxo11 dagegen nur mit den genomischen DNA-Präparationen von Sarcocystis gigantea, Isospora canis und Isospora felis auf. Isospora spp. und Sarcocystis spp. werden als sehr wirtssspezifisch für die Zwischenwirte angesehen (Tenter et al. 1995; Lindsay et al. 1997). Während Isospora canis und Isospora felis am häufigsten bei Hunden und Katzen vorkommen, kann Sarcocystis gigantea oft eine Infektion bei Schafen verursachen und am häufigsten in Speiseröhre- und Zungenmuskulatur vorkommen. Allerdings können andere Spezies von Isospora und Sarcocystis Hühner und Schweine infizieren. Z.B. wurden Isospora suis, I. almataensis und I. neyrai aus dem Schwein isoliert. Dabei stellt der Dünndarm die bevorzugte Stelle für Isospora-Arten dar (Lindsay 1997). Während das Schwein ein Zwischenwirt 
von zwei oder drei Arten von Sarcocystis (häufig S. miescheriana und S. suihominis) ist, können sich Hühner oft mit $S$. horvathi infizieren. Hier kommen diese Arten in Muskelgewebe inres Wirts vor (Lindsay 1995; Tenter 1995). Das bedeutet, dass bei Untersuchung von Gewebeproben mit unbekanntem Infektionsstatus (aus Freilandhaltungstieren) mittels 529-bp-PCR eine Kreuzreaktion mit Sarcocystis spp. auftreten könnte. In diesem Fall können serologische Verfahren (z.B. ELISA, IFAT) zum Nachweis spezifischer Antikörper gegen Sarcocystis spp. und Toxoplasma gondii bei der Differentialdiagnose helfen. Serologische Kreuzreaktionen sind aber bei niedrigen Titerwerten möglich. Bei Untersuchungen von Moon (1987) traten bei experimentell mit $T$. gondii infizierten Schweinen Kreuzreaktionen gegen SarcocystisAntigen bis zu 1:16 in IFA und bis zu 1:32 in ELISA auf. Ausgehend von diesen Erkenntnissen eignet sich unsere real-time PCR für den Nachweis von T. gondii-DNA im Gewebe von Hühnern und Schweinen, die experimentell mit dem Erreger infiziert wurden und nicht für Proben mit unbekanntem Infektionsstatus wegen des Kreuzreaktionsrisikos mit Sarcocystis. Deshalb wurde das Primerpaar Toxo9/Toxo11 in dieser Arbeit weiter für die 529-bp-PCR zum Nachweis von T. gondii-DNA in Schweine- und Hühnergeweben verwendet.

\subsection{Nachweis von Toxoplasma gondii in Gewebeproben experimentell infizierter Schweine}

Die experimentell infizierten Schweine wurden an unterschiedlichen Tagen auf die Existenz von Antikörpern gegen T. gondii untersucht. Mittels ELISA reagierten alle infizierten Tiere deutlich positiv. Abhängig von der Infektionsdosis wies der Antikörperanstieg in Schweineseren unterschiedliche Zeitpunkte auf. Bei Tieren mit hoher Infektionsdosis stiegen die Antikörpertiter gegen Toxoplasma gondii früher an als bei jenen, die mit geringer Infektionsdosis infiziert worden waren. Somit konnte die Infektion der Schweine mit Hilfe des ELISA-Verfahrens bestätigt werden.

Verschiedene Gewebeproben (Gehirn und unterschiedliche Muskelgewebe) wurden von den experimentell infizierten Schweinen entnommen und auf das Vorhandsein von Toxoplasma-DNA mit Hilfe der real-time PCR untersucht. Erreger wurden erfolgreich sowohl im Gehirn als auch in verschiedenen Muskelgeweben der Schweine detektiert. Dabei waren neun der zehn infizierten Schweinen mittels realtime PCR zumindest in einem Gewebe positiv für den Nachweis von Toxoplasma- 
DNA. Es gab dabei keinen deutlichen Zusammenhang zwischen der Infektionsdosis und dem Nachweis von T. gondii-DNA im Gewebe. Im Gegensatz zur Serologie ergab die real-time PCR jedoch bei einem mit 1000 Oozysten infizierten Schwein (Nr. 8) negative Ergebnisse in allen getesteten Proben. Dennoch bedeutet das, dass mittels dieser Methode ein hoher Prozentsatz von Positivität erreicht wurde (lediglich ein Schwein von zehn war negativ). Samico Fernandes et al. (2012) detektierten T. gondii-DNA in 21 von 38 seropositiven Schweinen. Eine eventuelle Interpretation für die negativen PCR-Ergebnisse ist nach Angaben von Esteban-Redondo et al. (1999), Yai et al. (2003), Hill et al. (2006) und Bezerra et al. (2012), dass insbesondere bei großen Tieren der Nachweis von Toxoplasma-Gewebezysten aus verschiedenen Gründen schwierig ist. Dazu gehören die unregelmäßige Verteilung der Parasiten im Gewebe von fleischliefernden Tieren, das von dem Erreger jeweils bevorzugte Gewebe sowie der niedrige Probenumfang, der für die Untersuchung mittels PCR verwendet wird, im Vergleich zu dem gesamten Wirtsumfang (EstebanRedondo et al. 1999; Yai et al. 2003; Hill et al. 2006; Bezerra et al. 2012). Ausgehend davon sind falsch-negative Ergebnisse zu erwarten und die negativen PCRErgebnisse in einer Gewebeprobe deuten nicht notwendigerweise darauf hin, dass das ganze Organ als T. gondii-negativ angesehen werden kann.

Die Verteilung von T. gondii-DNA im Gewebe der experimentell infizierten Schweine zeigte, dass Oberschenkelmuskulatur mit $70 \%$ und Bauchmuskulatur mit $60 \%$ am häufigsten betroffen waren. Der Erreger wurde auch im Vorderbein und im Gehirn mit je $40 \%$ nachgewiesen, am wenigsten waren Herz mit $30 \%$ und Zunge mit 10\% betroffen. Diese Ergebnisse sind vereinbar mit den Erkenntnissen, dass T. gondii in infizierten Schweinen bevorzugt in Muskelgeweben persistiert (Tenter et al. 2000). Obwohl unterschiedliche Studien gezeigt haben, dass T. gondii in Nagern neurotrop ist, deuten verschiedene Studien mit Nutztieren darauf hin, dass die Persistenz von T. gondii dort im Muskelgewebe effizienter ist als im Gehirn (Dubey und Beattie 1988; Dubey et al. 1996). Belfort-Neto et al. (2007) untersuchten Gewebeproben von 50 Schweinen in Erechim, Brasilien, dabei konnte der Erreger in der Zunge von 66\% und im Zwerchfellmuskel von 34\% der Schweine detektiert werden. Darüber hinaus konnten Dubey et al. (1988) bei 5 von 16 Schweinen lebende Toxoplasmen aus kommerziell vermarkteten Fleischstücken (Schulter, Schwanz, Schälrippchen, Keule) isolieren. Diese Informationen weisen darauf hin, dass die Persistenz von T. gondii in den verschiedenen essbaren Muskelgeweben des Schweins und der Verzehr von 
nicht ausreichend erhitztem Fleisch oder Fleischprodukten das Übertragungsrisiko auf den Menschen deutlich erhöht.

Die Quantifizierung des Erregers in den T. gondii-positiven Gewebeproben ergab eine Parasitenanzahl von 0,1 bis 4,1 in 25 mg Gewebe. Dabei gab es keine deutlichen Unterschiede in den Parasitenmengen in Abhängigkeit von der Gewebeart, obwohl Gewebe wie Oberschenkelmuskulatur und Bauchmuskulatur, die besonders häufig positiv für T. gondii-DNA waren, in einzelnen Proben die größten Mengen von Parasiten-DNA enthielten. Im Gewebe der fleischliefernden Tiere ist die T. gondiiMenge sehr gering, so wurde geschätzt, dass nur etwa eine Gewebezyste in $100 \mathrm{~g}$ Fleisch vorhanden ist (Hill und Dubey 2002). Vermutlich können diese Erkenntnisse als Erklärung für die geringen Parasitenanzahlen in den untersuchten Geweben dienen. Dazu kann auch der in dieser Arbeit festgestellte negative Einfluss des Wirtsgewebes auf die Sensitivität der real-time PCR beitragen (Kapitel 3.2.2). Dabei wurde nachgewiesen, dass die Sensitivität der real-time PCR im Gewebe zehnfach geringer ist als ohne Gewebe. Das bedeutet, dass eine Parasitenanzahl von 0,1 bis 4,1 in $25 \mathrm{mg}$ Schweinegewebe in der Realität zehnfach höher sein sollte, dass also tatsächlich eine Anzahl von 1 bis 40 Parasiten pro 25 mg Gewebe vorkommen. Ausgehend davon erhöht sich das Übertragungsrisiko der Infektion auf den Menschen durch Verzehr von rohem oder unzureichend gekochtem Schweinfleisch deutlich.

\subsection{Nachweis von Toxoplasma gondii in Gewebeproben experimentell infizierter Hühner}

Alle infizierten Hühner waren serologisch mit Hilfe des Toxoscreen DA-Tests positiv auf den Nachweis von T. gondii-Antikörper. Damit wurde die Infektion der untersuchten Hühner bestätigt. Gewebeproben wie Herz, Oberschenkelmuskulatur, Brustmuskulatur und Gehirn wurden von jedem Huhn entnommen und auf Vorliegen von T. gondii-DNA mittels real-time PCR untersucht. Mittels real-time PCR wurde spezifische Toxoplasma-DNA bei 11 von 12 Hühnern mindestens in einem Gewebe detektiert. Das zeigt wie bei Schweinen auch bei Hühnern einen hohen Prozentsatz von Positivität (> 90\% der untersuchten Hühner). Der Nachweis von Toxoplasma gondii in Geweben der experimentell infizierten Hühner und auch die Verteilung des Parasiten in einzelnen Geweben waren unabhängig von der verwendeten Infektions- 
dosis. In den untersuchten Hühnern konnte T. gondii am häufigsten im Gehirngewebe, in der Oberschenkelmuskulatur sowie in der Brustmuskulatur mit jeweils 50\% nachgewiesen werden. Dagegen wies das Herz mit ungefähr $20 \%$ eine deutlich geringere Häufigkeit auf. Diese Ergebnisse zeigen, dass Muskelgewebe von Hühnern wie auch von Schweinen wichtige Organe zur Erregerpersistenz darstellen. Zum Vergleich wurde in verschiedenen Studien von Dubey et al. $(2004,2005)$ beobachtet, dass Toxoplasma gondii bei Hühnern eine größere Tendenz hat, im Herz lokalisiert zu persistieren als im Skelettmuskel und im Gehirn. Andere Untersuchungen zeigten, dass das Herz und das Gehirn zu jenen Organen von Hühnern gehörten, die von Toxoplasma gondii bevorzugt werden (Aigner et al. 2010; Yan et al 2010; Dubey 2010) und dass persistierende T. gondii in der Brustmuskulatur weniger häufig vorkommen als in anderen Hühnergeweben (Dubey 2010; Hill und Dubey 2013). In einem Übersichtsartikel fasste Dubey (2010) Untersuchungen auf Vorhandsein von $T$. gondii in Hühnergewebe aus verschiedenen Ländern zusammen. Dabei wurden 149 Hühner mittels Bioassay untersucht und der Erreger am häufigsten aus dem Herz mit 89,5\% isoliert. T. gondii konnte auch im Gehirn mit 49,2\%, Oberschenkel mit 44,1\% und am wenigsten im Brustmuskel mit 18,6\% nachgewiesen werden. Yan et al. (2010) untersuchten mittels PCR (ITS1-abgeleitete Primer) auch das Vorliegen von Toxoplasma gondii in unterschiedlichen Hühnergeweben. Hier waren Herz und Lunge mit jeweils 5 von 20 Proben am häufigsten infiziert, in 4 von 20 Proben waren Gehirn, Milz und Auge betroffen.

Ähnlich der Ergebnisse von Schweinegeweben stellt die unregelmäßige Verteilung des Erregers im Tierkörper und der geringe Probenumfang (in dieser Arbeit $25 \mathrm{mg}$ Gewebe) eine eventuelle Erklärung für die negativen PCR-Ergebnisse im Hühnergewebe dar (Esteban-Redondo et al. 1999; Yai et al. 2003; Hill et al. 2006; Bezerra et al. 2012). Außerdem wurde in dieser Arbeit im Vergleich zu anderen Studien eine geringere Probenanzahl untersucht, darüber hinaus wurde in manchen Studien nur das Vorhandensein von lebenden Parasiten untersucht (Dubey 2010). Bezüglich der hier festgestellten geringen Infektionsrate im Herzgewebe im Vergleich zu den anderen Studien könnten der verwendete Parasitenstamm oder der Hühnerstamm eine Rolle spielen.

Zusätzlich zur Infektionsverteilung wurde auch bei Hühnern die Parasitenanzahl in den T. gondii-positiven Gewebeproben berechnet. Dabei ergab sich eine Anzahl von 0,1 bis 4,9 in $25 \mathrm{mg}$ Gewebe, die unabhängig von der Gewebeart war. Die geringe 
Zystenanzahl im Gewebe von fleischliefernden Tieren (eine Gewebezyste in $100 \mathrm{~g}$ Fleisch) ist eine mögliche Erklärung für diese geringe Parasitenanzahl im Hühnergewebe (Hill und Dubey 2002). Aigner et al. (2010) konnten anhand der real-time PCR (529-bp-Fragment-PCR) das Vorliegen von Toxoplasma-DNA im Herz (mit 80,8\%) und Gehirngewebe (mit 84,6\%) von 26 serologisch positiven Hühnern nachweisen und quantifizieren. Durchschnittlich zeigte die Quantifizierung im Gehirn 437 Parasiten pro Gramm Gewebe und im Herz 155 Parasiten pro Gramm Gewebe. In dieser Studie wurde kein signifikanter Unterschied in der Infektionsrate oder in den Parasitenmengen zwischen den beiden Geweben festgestellt. Im Vergleich wurde in der vorliegenden Arbeit eine Anzahl von 1,2 bis 3,4 Parasiten im Herz und von 0,2 bis 4,9 Parasiten im Gehirn pro $25 \mathrm{mg}$ Gewebe nachgewiesen. Wenn man diese Parasitenanzahl pro Gramm Gewebe berechnet, bedeutet das eine Anzahl von 48 bis 136 Parasiten im Herz und von 8 bis 196 Parasiten im Gehirn pro Gramm Gewebe. Der Unterschied in Parasitenanzahl im Vergleich zu der oben genannten Studie könnte auf die verwendete Methode zurückgeführt werden. Dabei wurde in der Studie von Aigner et al. (2010) das ganze Organ entnommen, in einer Pepsinlösung verdaut, zentrifugiert, das Pellet resuspendiert und DNA aus $400 \mu \mathrm{l}$ extrahiert und dann mittels real-time PCR amplifiziert.

\subsection{Nukleinsäure-basierte Untersuchung der Viabilität von T. gondii im Gewebe experimentell infizierter Hühner und Schweine}

Im Anschluss an den T. gondii-DNA-Nachweis in den unterschiedlichen Geweben von experimentell infizierten Hühnern und Schweinen wurde die Viabilität des Parasiten in diesen Geweben untersucht. Nur der Nachweis von lebenden Parasiten in Fleisch oder Fleischprodukten erlaubt eine genaue Schätzung des tatsächlichen Risikos für die öffentliche Gesundheit (Bezerra et al. 2012). Da DNA stabil ist und ein DNA-Nachweis lebende von toten Parasiten nicht unterscheiden kann und weil RNA instabil ist und mit hoher Wahrscheinlichkeit nur in lebenden Parasiten nachgewiesen werden kann, wurde $T$. gondii-mRNA in Toxoplasma-DNA-positiven Gewebeproben von infizierten Hühnern und Schweinen mittels reverser Transkriptase-real-time PCR (RT-real-time PCR) untersucht. Zunächst wurde die Sensitivität der RT-real-time 
PCR bestimmt. Dafür dienten die mit bekannten Tachyzoiten-Mengen inokulierten Mausgewebe (Gehirn und Muskelgewebe) sowie eine Verdünnungsreihe von T. gondii-Gewebezysten aus Gehirnen infizierter Mäuse für den spezifischen Nachweis von Sag1-mRNA (tachyzoitenspezifisch) bzw. von Bag1-mRNA (bradyzoitenspezifisch). Außerdem wurde Actin als housekeeping-Gen von T. gondii durch realtime PCR amplifiziert. Mittels RT-real-time PCR war die Sensitivität des Sag1-mRNANachweises deutlich besser als die von Toxoplasma-Actin-mRNA. Sag1-mRNA wurde in Proben ohne Wirtsgewebe bereits ab einer Parasitenmenge von 10 und in Proben mit $10^{4}$ oder mehr Parasiten pro 25 mg Mausgewebe detektiert. Die in dieser Arbeit festgestellte hemmende Wirkung von Gewebe erklärt die geringere Sensitivität der RT-real-time PCR im Gewebe im Vergleich zur PCR von Parasiten-DNA ohne Gewebe. Durch RT-real-time PCR zum Nachweis von T. gondii-mRNA in Gehirnen infizierter Mäuse konnte Actin-mRNA ab einer Menge von 0,1 und Bag1-mRNA ab einer Menge von 0,01 isolierter Toxoplasma-Zysten oder mehr nachgewiesen werden. Entsprechend detektierten Meyer et al. (2000) mittels RT-real-time PCR Sag1 ab 11 Tachyzoiten und Bag1 ab 1 Bradyzoiten. Um die Stadienspezifität sicherzustellen, wurde Sag1-Primer mit cDNA aus isolierten Toxoplasma-Zysten getestet. Die Untersuchung mit Hilfe der RT-real-time PCR ergab in zwei Proben (mit 0,0001 und 1 Zysten) schwach positive Testergebnisse, die größer als der errechnete Grenzwert waren. Bei der Überprüfung der Spezifität der real-time PCR anhand der zugehörigen Schmelzkurve wurde dies als unspezifisch identifiziert, da die erhaltenen Schmelzkurven nicht denen der Positivkontrolle entsprachen. So konnten in diesem Versuch lebende Parasiten durch Amplifikation von Sag1 und Bag1-mRNA mit Hilfe der RT-real-time PCR nachgewiesen werden. Allerdings war die Sensitivität dieser Methode im Vergleich zum T. gondii-DNA-Nachweis im Mausgewebe (Kapitel 3.1.1) deutlich geringer.

Um zu ermitteln, ob die nachgewiesene Parasiten-DNA im Gewebe der experimentell infizierten Hühner und Schweine von lebenden Toxoplasmen stammen könnte, wurden unterschiedliche Toxoplasma-DNA-positive Gewebeproben (25 mg Gewebe) auf das Vorhandsein von Toxoplasma-mRNA untersucht. Alle untersuchten Gewebeproben der experimentell infizierten Hühner und Schweine waren in der RT-realtime PCR negativ auf den Nachweis von Bag1-cDNA. So konnte T. gondii-mRNA und damit lebende Parasiten in den untersuchten Gewebeproben nicht nachgewiesen werden. Die geringere Sensitivität der RT-real-time PCR zum mRNA-Nachweis 
in den Gewebeproben kann vermutlich als Erklärung für diese negativen PCRErgebnisse dienen. Diese geringe Sensitivität geht vermutlich auf die geringe Kopienzahl des Targets zurück, wobei Sag1-Gen und Bag1-Gen je nur in einzelner Kopie im Toxoplasma-Genom vorkommen (Burg et al. 1988; Bohne et al. 1995). Weil RNA instabil ist, ist RNA-Abbau während der Isolierung als Ursache ebenfalls nicht komplett auszuschließen. RNA wurde in cDNA umgeschrieben, was zu einem weiteren Targetverlust beitragen könnte. Außerdem kann auch die geringe Zystenanzahl im Gewebe der Nutztiere (nur eine Gewebezyste in $100 \mathrm{~g}$ Fleisch) (Hill und Dubey 2002) eine Rolle spielen. Die Viabilität von Toxoplasma gondii im Gewebe der fleischliefernden Nutztiere, darunter Hühner und Schweine, wurde von unterschiedlichen Autoren nachgewiesen (Dias et al. 2005; Dubey 2009, 2010; Bezerra et al. 2012). In diesen Studien diente der Bioassay in der Maus als Methode, um lebende Parasiten aus dem untersuchten Gewebe zu isolieren. Der Bioassay konnte lebende Toxoplasmen nachweisen und zeigte damit eine bessere Sensitivität zur Beurteilung der Viabilität im Vergleich zu der in dieser Arbeit verwendeten RT-real-time PCR. Ausgehend davon ist diese Methode nicht geeignet für die routinemäßige Diagnose von lebenden Parasiten und stellt daher keine Alternative für die Bioassay dar.

Durch Etablierung einer real-time PCR konnte mit guter Sensitivität T. gondii-DNA in verschiedenen Muskelgewebe von Hühnern und Schweinen nachgewiesen werden. Das Vorhandensein des Erregers im Fleisch dieser Nutztiere stellt ein Risiko für die Übertragung auf den Menschen dar, wenn Fleisch oder Fleischprodukte roh oder nicht ausreichend erhitzt verzehrt wurden. 


\section{Zusammenfassung}

Toxoplasma gondii ist weltweit einer der häufigsten zoonotischen Parasiten. Der Erreger kann alle warmblütigen Tiere einschließlich des Menschen infizieren. Die Toxoplasmose des Menschen verläuft in der Regel asymptomatisch. Allerdings hat die Infektion eine große Bedeutung während der Schwangerschaft und bei immunsupprimierten Patienten. 30\% - 63\% der Toxoplasma-Infektionen des Menschen erfolgen durch die orale Aufnahme von Gewebezysten aus rohem oder unzureichend erhitztem Fleisch (Cook et al. 2000). Fleischlieferende Nutztiere wie Schweine, Schafe, Ziegen und Geflügel gelten als eine wichtige Infektionsquelle für den Menschen. Allerdings variieren Anzahl und Lokalisation der Gewebezysten zwischen verschiedenen Tierarten. Das Ziel dieser Arbeit war der Nachweis von ToxoplasmaDNA in verschiedenen Muskulaturgeweben von Schweinen und Hühnern nach oraler Infektion mit Oozysten. Außerdem wurde untersucht, welche Gewebe Prädilektionsstellen für die Persistenz von $T$. gondii darstellen können und was das für die Übertragung der Infektion auf den Menschen bedeutet. Der Konsum von Schweineund Hühnerfleisch in Deutschland ist groß, deshalb wurden diese beiden Tiere in dieser Arbeit untersucht.

Zuerst wurde eine real-time PCR auf Basis des 529-bp-Fragments von Toxoplasma gondii etabliert. Anhand bekannter Parasitenmengen wurde eine Standardkurve erstellt; dabei wurde T. gondii-DNA in Mengen von 2,5 oder mehr Tachyzoiten pro $25 \mathrm{mg}$ Gewebe nachgewiesen. Untersuchungen zur Sensitivität zeigten, dass die real-time PCR sensitiver als eine nested PCR war, und dass die Sensitivität der PCR bei Amplifikation von Parasiten-DNA in Gegenwart von Muskel- oder Gehirngewebe etwa zehnfach geringer war als jene von Parasiten ohne Gewebe. Untersuchungen zur Spezifität der real-time PCR mit genomischer DNA verschiedener CoccidiaParasiten zeigten Kreuzreaktionen mit der DNA von Sarcocystis gigantea, Isospora canis und $I$. felis, die bei Feldisolaten zu Toxoplasma-falsch-positiven Ergebnissen führen könnten.

Im Zusammenarbeit mit dem Institut für Parasitologie, Tierärztliche Hochschule Hannover (AG Prof. A. Tenter) wurden 10 Schweine und 12 Hühner experimentell mit unterschiedlichen Infektionsdosen von Toxoplasma-Oozysten infiziert und verschiedene Gewebeproben entnommen. Anhand der 529-bp-PCR waren 90\% der untersuchten Schweine und $>90 \%$ der untersuchten Hühner Toxoplasma-DNA- 
positiv. In Schweinen gelang der Nachweis von Toxoplasma-DNA in Oberschenkelmuskulatur mit 70\% und Bauchmuskulatur mit 60\% am häufigsten. Gehirn und Vorderbeinmuskulatur waren mit jeweils $40 \%$, Herz mit $30 \%$ und Zunge mit $10 \%$ Toxoplasma-DNA-positiv. In experimentell infizierten Hühnern wurde T. gondii-DNA am häufigsten in Oberschenkelmuskulatur, Brustmuskulatur und Gehirn mit jeweils $50 \%$ und im Herz mit ungefähr 20\% nachgewiesen. Dabei gab es keinen deutlichen Zusammenhang zwischen der Infektionsdosis und dem Nachweis von T. gondii-DNA im Gewebe. Die Quantifizierung des Erregers in den T. gondii-positiven Gewebeproben ergab eine Parasitenanzahl von 0,1 bis 4,1 in $25 \mathrm{mg}$ Schweinegewebe und von 0,1 bis 4,9 in 25 mg Hühnergewebe, die unabhängig von der Gewebeart war. Ausgehend von diesen Ergebnissen stellen die Muskulatur von Schweinen und Hühnern ein wichtiges Gewebe für die Persistenz von T. gondii in diesen fleischliefernden Tieren dar,

Da DNA relativ stabil ist, kann ihr Nachweis nicht als Indiz für lebende Parasiten gelten. Ein DNA-Nachweis erlaubt daher keinen eindeutigen Hinweis auf das tatsächtlichen Infektionrisiko bei Fleischverzehr. Deshalb wurde in dieser Arbeit auch eine reverse Transkriptase-real-time PCR etabliert, um lebende Parasiten in den infizierten Geweben der Schweine und Hühner durch Nachweis von T. gondii-mRNA zu detektieren. Dafür wurden Sag1-mRNA (tachyzoitenspezifisch) und Bag1-mRNA (bradyzoitenspezifisch) amplifiziert. Die Sensitivität dieser Methode war geringer als die der real-time PCR für T. gondii-DNA und konnte in experimentell infizierten Schweinen und Hühnern keine lebenden Parasiten detektieren. Deshalb bleibt der Bioassay in der Maus die geeignetere Methode für Untersuchungen der Viabilität des Erregers im Gewebe.

Die Ergebnisse dieser Arbeit zeigen, dass Muskulatur von Schweinen und Hühnern bevorzugte Orte für die Persistenz von T. gondii in diesen fleischliefernden Tieren darstellen. Das ist ein wichtiger Hinweis, dass bei Verzehr von rohem oder nicht ausreichend erhitztem Fleisch oder Fleischprodukten dieser Tiere ein potenzielles Infektionsrisiko für den Menschen besteht. 


\section{Literaturverzeichnis}

Aigner CP, da Silva AV, Sandrini F, Osório P de S, Poiares L, Largura A (2010): Real-time PCR-based quantification of Toxoplasma gondii in tissue samples of serologically positive outdoor chickens. Mem Inst Oswaldo Cruz 105, 935-937.

Alvarado-Esquivel C, Estrada-Martinez S (2011): Toxoplasma gondii infection and abdominal hernia: evidence of a new association. Parasit Vectors $\underline{4}, 112$.

Bahia-Oliveira LM, Wilken de Abreu AM, Azevedo-Silva J, Oréfice F (2001): Toxoplasmosis in southeastern Brazil: an alarming situation of highly endemic acquired and congenital infection. Int J Parasitol $\underline{31}$, 133-136.

Bahia-Oliveira LM, Jones JL, Azevedo - Silva J, Alves CC, Oréfice F, Addiss DG (2003): Highly endemic, waterborne toxoplasmosis in north Rio de Janeiro State, Brazil. Emerg Inf Dis $\underline{9}, 55-62$.

Baril L, Ancelle T, Goulet V, Thulliez P, Tirard-Fleury V, Carme B (1999): Risk factors for Toxoplasma infection in pregnancy: a case-control study in France. Scand $J$ Infect Dis $\underline{31}, 305-309$.

Belfort-Neto R, Nussenblatt V, Rizzo L, Muccioli C, Silveira C, Nussenblatt R, Khan A, Sibley LD, Belfort JrR (2007): High prevalence of unusual genotypes of Toxoplasma gondii infection in pork meat samples from Erechim, Southern Brazil. An Acad Bras Cienc $\underline{79}, 111-114$.

Bellete B, Flori P, Hafid J, Raberin H, Tran Manh Sung R (2003): Influence of the quantity of nonspecific DNA and repeated freezing and thawing of samples on the quantification of DNA by the Light Cycler. J Microbiol Meth $\underline{55}, 213-219$.

Bezerra RA, Carvalho FS, Guimaraes LA, Rocha DS, Silva FL, Wenceslau AA, Albuquerque GR (2012): Comparison of methods for detection of Toxoplasma gondii in tissues of naturally exposed pigs. Parasitol Res $\underline{110}, 509-514$. 
Bohne W, Groß U, Ferguson DJ, Heesemann J (1995): Cloning and characterization of a bradyzoite-specifically expressed gene (hsp30/bag1) of toxoplasma gondii, related to genes encoding small heat-shock proteins of plants. Mol Microbiol $\underline{16}$, 1221-1230.

Bonametti AM, Passos JN, Koga da Silva EM, Macedo ZS (1997): Probable transmission of acute toxoplasmosis through breast feeding. J Trop Pediatr $\underline{43}, 116$.

Bowie WR, King AS, Werker DH, Isaac-Renton JL, Bell A, Eng SB, MARION SA (1997): Outbreak of toxoplasmosis associated with municipal drinking water. Lancet 350, $173-177$.

Bundesverband der Deutschen Fleischwarenindustrie e. V. (2009): Geschäftsbericht 2008/2009. http://www.bvdf.de/.

Burg JL, Perelman D, Kasper LH, Ware PL, Boothroyd JC (1988): Molecular analysis of the gene encoding the major surface antigen of Toxoplasma gondii. J Immunol 141, 3584-3591.

Calderaro A, Piccolo G, Gorrini C, Peruzzi S, Zerbini L, Bommezzadri S, Dettori G, Chezzi C (2006): Comparison between two Real-Time-PCR assays and a nestedPCR for the detection of Toxoplasma gondii. Acta Biomed $\underline{77}, 75-80$.

Cook AJ, Gilbert RE, Buffolano W, Zufferey J, Petersen E, Jenum PA, Foulon W, Semprini AE, Dunn DT (2000): Sources of toxoplasma infection in pregnant women: European multicentre case - control study. Br Med J $\underline{321}, 142$ - 147.

da Silva DS, Bahia-Oliveira LM, Shen SK, Kwok OC, Lehman T, Dubey JP (2003): Prevalence of Toxoplasma gondii in chickens from an area in southern Brazil highly endemic to humans. J Parasitol $\underline{89}$, 394-396.

Dias RA, Navarro IT, Ruffolo BB, Bugni FM, Castro MV, Freire RL (2005): Toxoplasma gondii in fresh pork sausage and seroprevalence in butchers from factories in Londrina, Paraná State, Brazil. Rev Inst Med Trop São Paulo 47, 185 - 189. 
Dubey JP (1988): Long-term persistence of Toxoplasma gondii in tissues of pigs inoculated with T. gondii oocysts and effect of freezing on viability of tissue cysts in pork. Am J Vet Res $\underline{49}, 910-13$.

Dubey JP (2009): Toxoplasmosis in pigs - The last 20 years. Vet Parasitol 164, 89103.

Dubey JP (2010): Toxoplasma gondii infection in chickens (Gallus domesticus): prevalence, clinical disease, diagnosis, and public health significance. Zoonoses Public Health $\underline{57}$, 60-73.

Dubey JP, Frenkel JK (1972): Cyst-induced toxoplasmosis in cats. J Protozool $\underline{19}$, 155-177.

Dubey JP, Frenkel JF (1976): Feline toxoplasmosis from acutely infected mice and the development of Toxoplasma cysts. J. Protozool 23, $537-546$.

Dubey JP, Beattie CP (1988): Toxoplasmosis of animals and man. CRC Press, Boca Raton, Florida.

Dubey JP, Jones JL (2008): Toxoplasma gondii infection in humans and animals in the United States. Int J parasitol $\underline{38}, 1257-1278$.

Dubey JP, Ruff MD, Camargo ME, Shen SK, Wilkins GL, Kwok OC, Thulliez P (1993): Serologic and parasitologic responses of domestic chickens after oral inoculation with toxoplasma gondii oocysts. Am J Vet Res $\underline{12}$, 131-136.

Dubey JP, Lunney JK, Shen SK, Kwok OC, Ashford DA, Thulliez P (1996): Infectivity of low numbers of Toxoplasma gondii oocysts to pigs. J Parasitol $\underline{82}, 438-443$.

Dubey JP, Lindsay DS, Speer CA (1998): Structures of Toxoplasma gondii tachyzoites, bradyzoites, and sporozoites and biology and development of tissue cysts. Clin Microbiol Rev $\underline{11}$, 267-299. 
Dubey JP, Graham DH, Blackston CR, Lehmann T, Gennari SM, Ragozo Am, Nishi SM, Shen SK, Kwok OC, Hill DE, Thulliez P (2002): Biological and genetic characterisation of Toxoplasma gondii isolates from chickens (Gallus domesticus) from Sao Paulo, Brazil: unexpected findings. Int J Parasitol $\underline{32}$, 99-105.

Dubey JP, Levy MZ, Sreekumer C, Kwok OC, Shen SK, Dahl E, Thulliez P, Lehmann $T$ (2004): Tissue distribution and molecular characterization of chicken isolates of Toxoplasma gondii from Peru. J Parasitol 90, 1015-1018.

Dubey JP, Bhaiyat MI, de Allie C, Macpherson CN, Sharma RN, Sreekumer C, Vianna MCB, Shen SK, Kwok OC, , Lehmann T (2005): Isolation, tissue distribution, and molecular characterization of Toxoplasma gondii from chickens in Grenada, West Indies. J Parasitol 91, 557-560.

Dubey JP, Gennari SM, Labruna MB, Camargo LM, Vianna MC, Marcet PL, Lehmann $T$ (2006): Characterization of Toxoplasma gondii isolates in free-range chickens from Amazon, Brazil. J Parasitol 92, 36-40.

Dupouy-Camet J, Lavareda de Souza L, Maslo C, Paugam A, Saimot AG, Benarous R, Tourte-Schaefer C, Derouin F (1993): Detection of Toxoplasma gondii in venous blood from AIDS patients by polymerase chain reaction. J Clin Microbiol 31, 18661869.

Dzitko K, Staczek P, Gatkowska J, Dlugonska H (2006): Toxoplasma gondii: Serological recognition of reinfection. Exp Parasitol 112, 134-137.

Edvinsson B, Jalal S, Nord C-E, Stray-Pedersen B, Evengard B (2004): DNA extraction and PCR assays for detection of Toxoplasma gondii. APMIS $\underline{112}, 342-348$.

Edvinsson B, Lappalainen M, Evengard B (2006): Real time - PCR targeting a 529 - bp repeat element for diagnosis of toxoplasmosis. Clin Microbiol Infect $\underline{12}, 131$ $-136$. 
Eng SB, Werker DH, King AS, Marion SA, Bell A, Issac-Renton JL, Irwin GS, Bowie WR (1999): Computer-generated dot maps as an epidemiologic tool: investigating an outbreak of toxoplasmosis. Emerg Infect Dis $\underline{5}, 815-819$.

Ertug S, Okyay P, Turkmen M, Yuksel H (2005): Seroprevalence and risk factors for Toxoplasma infection among pregnant women in Aydin province, Turkey. BMC Public Health $\underline{5}, 66-71$.

Esteban - Redondo I, Maley SW, Thomson K, Nicoll S, Wright S, Buxton D, Innes EA (1999): Detection of T. gondii in tissues of sheep and cattle following oral infection. Vet Parasitol $\underline{86}, 155-171$.

Evengard B, Petersson K, Engman ML, Wiklund S, Ivarsson SA, Tear-Fahnehjelm K, Forsgren M, Gilbert R, Malm G (2001): Low incidence of toxoplasma infection during pregnancy and in newborns in Sweden. Epidemiol Infect 127, 121-127.

Ferguson DJ, Hutchison WM, Dunachie JF, Sim JC (1974): Ultrastructural study of early stages of asexual multiplication and microgametogon of Toxoplasma gondii in the small intestine of the cat. Acta Pathol Microbiol Immunol Scand $\underline{82}, 167-181$.

Foster BG, Forrest RG, Blanco JF (1969): Isolation of Toxoplasma gondii from naturally infected chicken. Tex J Sci $\underline{20}, 323-328$.

Frenkel JK: Biology of Toxoplasma gondii. In: Congenital toxoplasmosis: scientific background, clinical management and control; Hrsg. v. Ambroise-Thomas P, Petersen E. Springer-Verlag, Paris 2000, 9-25.

Frenkel JK, Dubey JP, Miller NL (1970): Toxoplasma gondii in cats: faecal stages identified as a coccidian oocysts. Science $\underline{167}, 893-896$.

Fux B, Nawas J, Khan A, Gill DB, Su C, Sibley LD (2007): Toxoplasma gondii strains defective in oral transmission are also defective in developmental stage differentiation. Infect Immun $\underline{75}$, 2580-2590. 
Gilbert RE, Stanford MR (2000). Is ocular toxoplasmosis caused by prenatal or postnatal infection? Br J Ophthalmol 84, 224-226.

Grover CM, Thulliez P, Remington JS, Boothroyd JD (1990): Rapid prenatal diagnosis of congenital Toxoplasma infection by using polymerase chain reaction and amniotic fluid. J Clin Microbiol 28, 2297-2301.

Groß U (2004): Prävalenz und Public - Health - Aspekte der Toxoplasmose. Bundesgesundheitsbl Gesundheitsforsch Gesundheitsschutz 47, 692 - 697.

Groß U, Müller WA, Knapp S, Heesemann J (1991): Identification of a virulenceassociated antigen of Toxoplasma gondii by use of a mouse monoclonal antibody. Infect Immun 59, 4511-4516.

Heukelbach J, Meyer-Cirkel V, Moura RC, Gomide M, Queiroz JA, Saweljew P, Liesenfeld O (2007): Waterborne toxoplasmosis, northeastern Brazil. Emrg Infect Dis 13, 287-289.

Hill D, Dubey JP (2002): Toxoplasma gondii: transmission, diagnosis and prevention. Clin Microbiol Infect $\underline{8}, 634-640$.

Hill DE, Dubey JP (2013): Toxoplasma gondii prevalence in farm animals in the United States. Int J Parasitol $\underline{43}, 107-113$.

Hill DE, Chirukandoth S, Dubey JP (2005): Biology and epidemiology of Toxoplasma gondii in man and animals. Anim Health Res Rev $\underline{6}, 41-61$.

Hill DE, Chirukandoth S, Dubey JP, Lunney JK, Gamble HR (2006): Comparison of detection methods for Toxoplasma gondii in naturally and experimentally infected swine. Vet Parasitol 141, $9-17$.

Ho MSY, Barr BC, Marsh AE, Anderson ML, Rowe JD, Tarantal AF, Hendrickx AG, Sverlow K, Dubey JP, Conrad PA (1996): Identification of bovine Neospora parasites 
by PCR amplification ans specific small-subunit rRNA sequence probe hypridization. J Clin Microbiol 34, 1203-1208.

Holland GN (2003): Ocular toxoplasmosis: a global reassessment. Part I : epidemiology and course of disease. Am J Ophthalmol $\underline{136}, 973-988$.

Homan WL, Vercammen M, De Braekeleer J, Verschueren H (2000): Identification of a 200 - to 300 - fold repetitive 529 bp DNA fragment in Toxoplasma gondii and ist use for diagnostic and quantitative PCR. Int J Parasitol $\underline{30}, 69$ - 75.

Hooshyar D, Hanson DL, Wolfe M, Selik RM, Buskin SE, McNaghten AD (2007): Trends in perimortal conditions and mortality rates among HIV-infected patients. AIDS 21, 2093-2100.

Hotop A, Hlobil H, Groß U (2012): Efficacy of rapid treatment initiation following primary Toxoplasma gondii infection during pregnancy. Clin Infect Dis $\underline{54}, 1545-1552$.

Hutchison WM, Dunachie JF, Siim JC, Work K (1970): Coccidian-like nature of Toxoplasma gondii. Br Med J 1, 142-144.

Ibrahim BB, Salama MM, Gawish NI, Haridy FM (1997): Serological and histopathological studies on toxoplasma Gondii among the workers and the slaughtered animals in Tanta Abattoir, Gharbia Governorate. J Egypt Soc Parasit 27, 273-278.

Jacobs L, Melton ML (1966): Toxoplasmosis in chickens. J Parasitol 므, 1158-1162. Foster BG, Forrest RG, Blanco JF (1969): Isolation of Toxoplasma gondii from naturally infected chickens. Tex J Sci $\underline{20}, 323-328$.

Jalal S, Nord CE, Lappalainen M, Evengård B (2004): Rapid and sensitive diagnosis of T. gondii infections by PCR. Clin Microbiol Infect 느, 937 - 939.

Jauregui LH, Higgins J, Zarlenga D, Dubey JP, Lunney JK (2001): Development of a Real-Time PCR assay for detection of Toxoplasma gondii in pig and mouse tissues. $J$ Clin Microbiol 39, 2065 - 2071. 
Jones JL, Sehgal M, Maguire JH (2002): Toxoplasmosis-associated deaths among Human Immunodeficiency Virus-infected persons in the United States, 1992-1998. Clin Infect Dis $\underline{34}, 1161$.

Kapperud G, Jenum PA, Stray - Pedersen B, Melby KK, Eskild A, Eng J (1996): Risk factors for Toxoplasma gondii infection in pregnancy: results of a prospective casecontrol study in Norway. Am J Epidemiol 144, 405 - 412.

Kijlstra A, Jongert E (2009): Toxoplasma-safe meat: close to reality? Trends Parasitol $\underline{25}, 18-22$.

Kijlstra A, Eissen OA, Cornelissen J, Munniksma K, Eijck I, Kortbeek T (2004): Toxoplasma gondii Infection in Animal-Friendly Pig Production Systems. Invest Ophthalmol Vis Sci $\underline{45}$, 3165-3169.

Koppe JG, Loewer-Sieger DH, de Roever-Bonnet H (1986): Results of 20-year follow-up of congenital toxoplasmosis. Lancet $\underline{1}, 254-256$.

Lebech M, Andersen O, Christensen NC, Hertel J, Nielsen HE, Peitersen B, Rechnitzer C, Larsen SO, Norgaard-Pedersen B, Petersen E, the Danish Congenital Toxoplasmosis Study Group (1999): Feasibility of neonatal screening for Toxoplasma infection in the absence of prenatal treatment. Lancet $\underline{353}, 1834-1837$.

Lehmann TP, Marcet L, Graham DH, Dahl ER, Dubey JP (2006): Globalization and the population structure of Toxoplasma gondii. Proc Natl Acad Sci USA $\underline{103}, 11423-$ 11428.

Lindsay DS, Blagburn BL, Braund KG (1995): Sarcocystis spp. and Sarcocystosis. BAM $\underline{5}, 249-254$.

Lindsay DS, Dubey Jp, Blagburn BL (1997): Biology of Isospora spp. from humans, nonhuman primates, and domestic animals. Clin Microbiol Rev $\underline{10}, 19$.

Ludewig M, de Buhr K, Fehlhaber K (2007): Toxoplasma gondii - Seroprävalenz in 
Mastschweinebeständen - Ergebnisse aus einer deutschlandweiten Studie. J Verbr Lebensm 2, $454-456$.

Luft BJ, Remington JS (1992): Toxoplasmic encephalitis in AIDS. Clin Infect Dis $\underline{15}$, 211-222.

Luft BJ, Conley F, Remington JS, Laverdiere M, Wagner KF, Levine JF, Craven PC, Strandberg DA, File TM, Rice N, Meunier-Carpentier F (1983): Outbreak of central nervous system toxoplasmosis in western Europe and North America. Lancet 1, 781784.

Meyer DJ, Allan JE, Beaman MB (2000): Distribution of parasite stages in tissues of toxoplasma gondii infected SCID mice and human peripheral blood lymphocytetransplanted SCID mice. Parasite Immunol 22

Montoya JG, Remington JS (1996): Toxoplasmic chorioretinitis in the setting of acute acquired toxoplasmosis. Clin infect Dis $\underline{23}, 277-282$.

Montoya JG, Liesenfeld O (2004): Toxoplasmosis. Lancet $\underline{363}, 1965-1976$.

Montoya JG, Parmley S, Liesenfeld O, Jaffe GJ, Remington JS (1999): Use of the polymerase chain reaction for diagnosis of ocular toxoplasmosis. Ophthalmology $\underline{106}, 1554-1563$.

Moon MH (1987): Serological cross-reactivity between Sarcocystis and Toxoplasma in pigs. Korean J Parasitol 25, 188-194.

Reischl U, Bretagne S, Krüger D, Ernault P, Costa J - M (2003): Comparison of two DNA targets for the diagnosis of toxoplasmosis by Real - Time PCR using fluorescence resonance energy transfer hybridization probes. BMC Infect Dis $\underline{3}, 7$.

Remington JS, McLeod R, Thulliez P, Desmonts G: Toxoplasmosis. In: Infectious Diseases of the Fetus and Newborn Infant; Hrsg. v. Remington JS, Klein JO, Wilson CB, Baker CJ. Elsevier Saunders, Philadelphia 2006, 947-1091. 
Sabin AB, Feldman HA (1948): Dyes as Microchemical Indicators of a New Immunity Phenomenon Affecting a Protozoon Parasite (Toxoplasma). Science 108, 660-663.

Samico Fernandes EF, Samico Fernandes MF, Kim PC, de Albuquerque PP, de Souza Neto OL, de S Santos A, de Moraes EP, de Morais EG, Mota RA (2012): Prevalence of Toxoplasma gondii in slaughtered pigs in the state of Pernambuco, Brazil. J Parasitol $\underline{98}$, 690-691.

Samuel R, Bettiker RL, Suh B (2002): AIDS Related Opportunistic infections, Going but not Gone. Arch Pharm Res $\underline{25}, 215-228$.

Schaffner A (2001): Pretransplant evaluation for infections in donors and recipients of solid organs. Clin Infect Dis $\underline{33}$ (Suppl 1), 9-14.

Schares G, Herrmann DC, Beckert A, Schares S, Hosseininejad M, Pantchev N, Globokar Vrhovec M, Conraths FJ (2008): Characterization of a repetitive DNA fragment in Hammondia hammondi and its utility for the specific differentiation of $\mathrm{H}$. hammondi from Toxoplasma gondii by PCR. Mol Cell Probes $\underline{22}, 244-251$.

Schulzig HS, Fehlhaber K (2005): Longitudinalstudie zur Seroprävalenz der Toxoplasma gondii - Infektion in vier deutschen Schweineaufzucht - und Mastbetrieben. Berl Münch Tierärztl Wochenschr 118, 399-403.

Skinner LJ, Timperley AC, Wightman D, Chatterton JM, Ho-Yen DO (1990): Simultaneous diagnosis of toxoplasmosis in goats and goatowner's family. Scand $\mathrm{J}$ Infect Dis $\underline{22}, 359-361$.

Sroka J (2006): Occurrence of Toxoplasma gondii in water from wells located on farms. Ann Agric Environ Med 13, 169-175.

Su C, Shwab EK, Zhou P, Zhu XQ, Dubey JP (2010): Moving towards an integrated approach to molecular detection and identification of Toxoplasma gondii. Parasitology $\underline{137}, 1-11$. 
Tenter AM (1995): Current research on Sarcocystis species of domestic animals. Int J Parasitol 25, 1311-1330.

Tenter AM (2009): Toxoplasma gondii in animals used for human consumption. Mem Inst Oswaldo Cruz 104, 364-369.

Tenter AM, Heckeroth AR, Weiss LM (2000): Toxoplasma gondii: from animals to humans. Int J Parasitol $\underline{30}$, 1217-1258.

Van der Giessen J, Fonville M, Bouuknegt M, Langelaar M, Vollema A (2007): Seroprevalence of Trichinella spiralis and Toxoplasma gondii in pigs from different housing systems in the Netherlands. Vet Parasitol $\underline{148}, 371-374$.

Vesco G, Buffolano W, La Chiusa S, Mancusa G, Caracappa S, Chianca A, Villari S, Curro V, Liga F, Petersen E (2007): Toxoplasma gondii infections in sheep in Sicily, southern Italy. Vet Parasitol $\underline{146}, 3-8$.

Wainwright KE, Miller MA, Barr BC, Gardner IA, Melli AC, Essert T, Packham AE, Truong-Solar M, Conrad PA (2007): Chemical inactivation of Toxoplasma gondii oocysts in water. J Parasitol $\underline{93}, 925-931$.

Walker M, Zunt JR (2005): Parasitic central nervous system infections in immunocompromised hosts. Clin Infect Dis $\underline{40}$, 1005-1015.

Warnekulasuriya MR, Johnson JD, Holliman RE (1998): Detection of Toxoplasma gondii in cured meats. Int J Food Microbiol $\underline{45}, 211$ - 215.

Weigel RM, Dubey JP, Siegel AM, Hoefling D, Reynolds D, Herr L, Kitron UD, Shen SK, Thulliez P, Fayer R, Todd TS (1995): Prevalence of antibodies to Toxoplasma gondii in swine in Illinois in 1992. J Am Vet Med Assoc 206, 1747 - 1751.

Wolf A, Cowan D, Paige BH (1939): Toxoplasmic encephalomyelitis III. A new case of granulomatous encephalomyelitis due to a protozoon. Am J Pathol 15, 657-694. 
Yai LEM, Vianna MCB, Soares RM, Cortez A, Freire RL, Richtzenhain LJ, Gennari SM (2003): Evaluation of experimental Toxoplasma gondii (Nicolle and Manceaux, 1909) infection in pigs by bioassay in mice and polymerrase chain reaction. Braz $\mathrm{J}$ Vet res Anim Sci $\underline{40}$, 227-234.

Yan C, Yue CL, Yuan ZG, Lin RQ, He Y, Yin CC, Xu MJ, Song HQ, Zhu XQ (2010): Molecular ans serological diagnosis of toxoplasma gondii infection in experimentally infected chickens. Vet Parasitol 173, 179-183.

Zakimi S, Kyan H, Oshiro M, Sugimoto C, Fujisaki K (2006): PCR-based discrimination of Toxoplasma gondii from pigs at an abattoir in Okinawa, Japan. J Vet Med Sci $\underline{68}, 401-404$.

Zhou P, Chen Z, Li HL; Zheng H, He S, Lin RQ, Zhu XQ (2011): Toxoplasma gondii infechtion in humans in China. Parasit Vectors $\underline{4}, 165$. 


\section{Danksagung}

Ich möchte mich herzlich bei meinem Doktorvater Prof. Carsten Lüder dafür bedanken, dass er mich in seiner Arbeitsgruppe aufgenommen hat. Ich danke ihm besonders für seine Geduld und sein Verständnis und vor allem für die großartige Ansprechbarkeit sowie für die gute Betreung, bis ich diese Arbeit angefertigt habe.

Ich danke herzlich Herrn Prof. Dr. med. U. Groß, dass er mir die Chance gegeben hat, meine Doktorarbeit und meine Weiterbildung im Gebiet Mikrobiologie, Virologie und Infektionsepidemiologie am Institut Universität Göttingen anzufertigen sowie für sein Verständis und sein Unterstützung während meiner Zeit im Institut.

Ein Dankeschön geht auch an alle Mitarbeiter und Dektoranden des Instituts für Medizinische Mikrobiologie, besonderes an die Toxoplasma-Arbeitsgruppe für die Freundlichkeit, Hilfsbereitschaft und Unterstützung bei Problemen.

Außerdem bedanke ich mich bei Arbeitsgruppe von Prof. A. Tenter (Institut für Parasitologie, Tierärztliche Hochschule Hannover) für die Durchführung der Infektion von Hühnern und Schweinen und für die Anfertigung der serologischen Untersuchungen sowie für die gute Zusammenarbeit. 


\section{Lebenslauf}

Am 9. September 1979 wurde ich, Maisalreem Muhammad, als Tochter von Jaber Muhammad und Juhaina Ibrahim in Tartous, Syrien, geboren.

Von 1985 bis 1997 besuchte ich die Schule in Tartous und im Jahr 1997 habe ich das Abitur bestanden.

Im Oktober 1997 begann ich mit dem Studium der Humanmedizin an der TischrinUniversität in Lattakia. Im November 2003 habe ich das Medizinstudium abgeschlossen. Im Jahr 2004 habe ich mit den postgradualen Studien der Laboratoriummedizin an der Al-Muassah-Klinik der Universität Damaskus angefangen.

Nachdem ich ein Stipendium der Uni Damaskus bekommen habe, bin ich im Februar 2008 nach Deutschland gereist, um Weiterbildung im Gebiet Mikrobiologie, Virologie und Infektionsepidemiologie und eine Promotion im Bereich der Parasitologie in der Abteilung Medizinische Mikrobiologie der Universitätsmedizin Göttingen anzufertigen. 